\title{
An evaluation of the feasibility and benefits of forest partnerships to develop tree plantations: case studies in the Philippines
}

Margaret M. Calderon and Ani Adiwinata Nawir

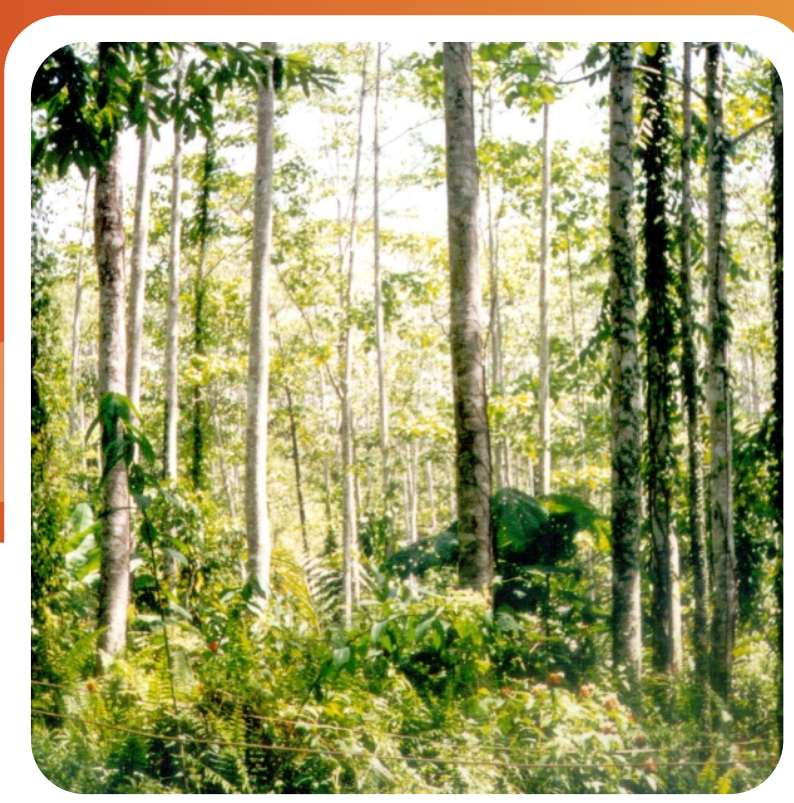

CIFOR Working Paper No. 27
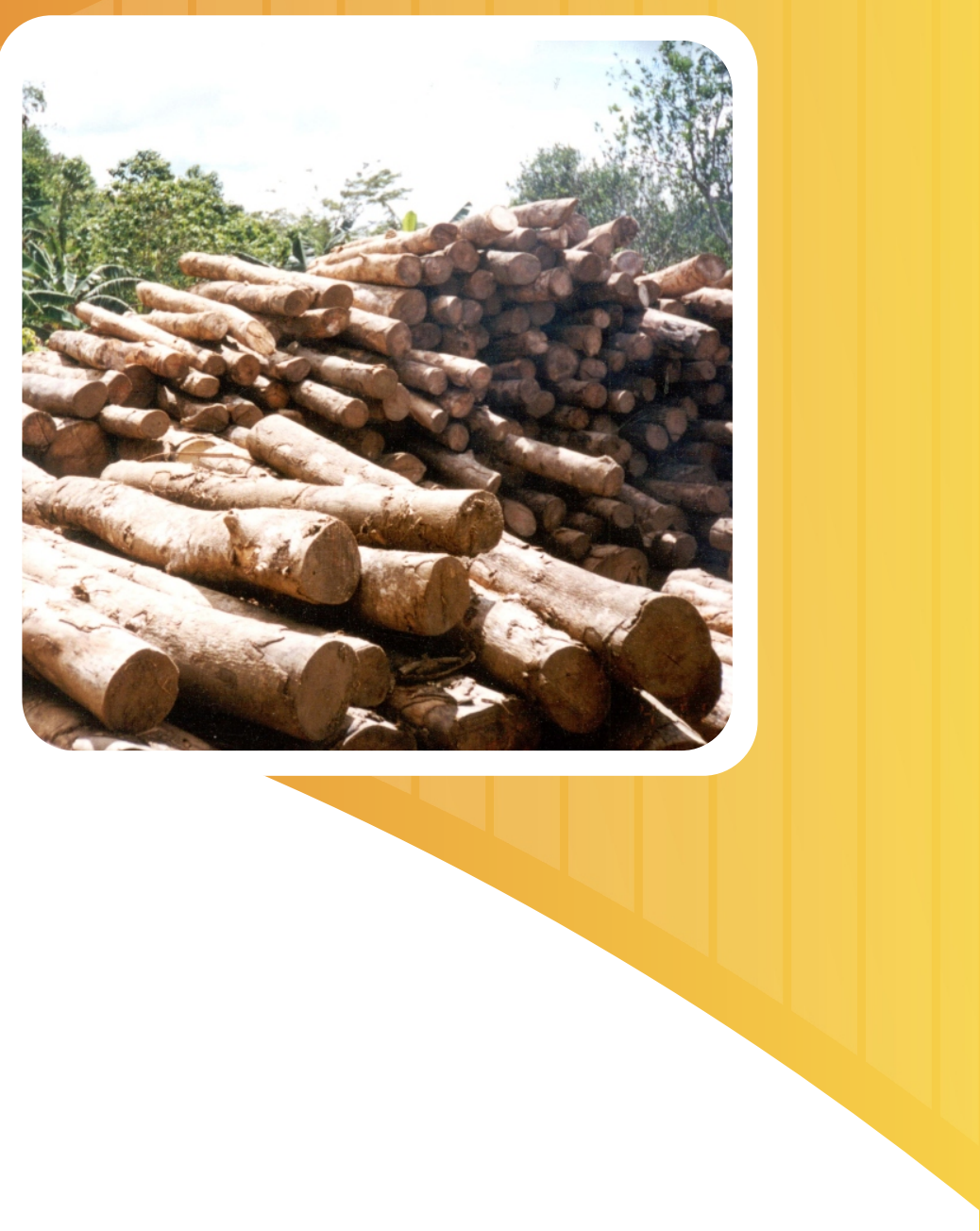
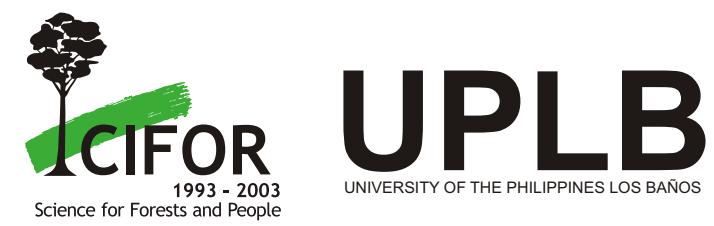


\section{An evaluation of the feasibility and benefits of forest partnerships to develop tree plantations: Case studies in the Philippines}

Margaret M. Calderon and Ani Adiwinata Nawir CIFOR Working Paper No. 27

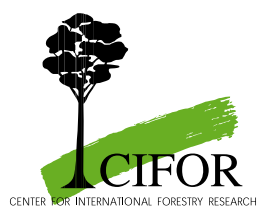

UPLB 
Cover photographer: Ani Adiwinata Nawir Graphic design and layout: Eko Prianto

(C) 2006 by Center for International Forestry Research All rights reserved. Published in 2006

Published by

Center for International Forestry Research

Office address: Jalan CIFOR, Situ Gede, Sindangbarang,

Bogor 16680, Indonesia

Mailing address: P.O. Box 6596 JKPWB, Jakarta 10065, Indonesia

Tel.: +62 (251) 622622; Fax:+62 (251) 622100

E-mail:cifor@cgiar.org

Web site: http://www.cifor.cgiar.org 


\section{Executive summary}

The study was conducted to evaluate the effectiveness of two forest management partnerships in the Philippines, namely the Community-Based Forest Management Program (CBFMP) and the Integrated Forest Management Program (IFMP). One CBFMP project and one IFMP project were chosen from each of the three major geographical regions in the country. The CBFMP sites were the Don Mariano Perez Farmers Multi-purpose Cooperative, Inc. (Luzon), Asosasyon sang Nagaproteher sang Kabukiran sa Jamindan (Visayas), and the Sta. Maria-Magkalape Tree Planters Association (Mindanao). The IFMP sites were the Woodland Wood Products, Inc. (Luzon), Iloilo Washington Commercial (Visayas), and the Casilayan Softwood Development Corporation (Mindanao).

The study involved a review of the policies relevant to tree plantation development in the country. The major stakeholders of the different projects were interviewed to ascertain the effectiveness of the schemes in terms of the management, economic, and social aspects. For CBFMP, these included the People's Organisation (PO), the Department of Environment and Natural Resources (DENR), local government units (LGUs), buyers, assisting organisations (AOs), and community members. For IFMP, the major stakeholders were the private companies, DENR, LGUs, buyers, and local communities/indigenous peoples (IPs).

The enabling policies for the successful implementation of the CBFMP and the IFMP are in place, and DENR continues to review and revise the policies to make them more responsive to its partners' needs and to enhance effectiveness. The government provides the agreement holders, in both CBFMP and IFMP, with various incentives to stimulate interest in tree growing. These include security of tenure $(25$ years, renewable for another 25 years), exemption from the payment of forest charges and permission to export logs and forest products harvested from the plantations. Within the policies it is also stated that the agreement holders' activities should not result in environmental degradation.

However, even the best-crafted policies are not a guarantee of success. Both CBFMP and IFMP will have a better chance of succeeding if the major stakeholders fully internalise their rights and responsibilities, and externalize these through responsible practices. For CBFMP, community organising should be carefully undertaken to ensure that the POs are empowered and capacitated to implement their Community Resources Management Framework. It is important for DENR to closely monitor the activities of the agreement holders, seeing to it that they faithfully implement their management plans, but with an open mind to accommodate possible changes if the situation warrants. The LGUs need to facilitate the resolution of conflicts between stakeholders, and to improve farm-to-market roads.

The financial analysis focused on the tree plantation component. The net present value (NPV) and the internal rate of return (IRR) were used to evaluate feasibility, using an interest rate of $15 \%$. The tree plantation components of two CBFMP and two IFMP projects included in this study were found to be financially feasible. The factors that could affect feasibility are the yield, costs of production (including transactions costs), and market conditions. 
The support that the government gives to CBFMA and IFMA holders in marketing their products appears to be insufficient. Despite the apparent shortage in log supply, as evidenced by the country's log importation, many tree growers still find difficulty in getting good prices for their products. In some cases, local tree growers cannot compete because imported logs are cheaper than locally produced logs. The local tree growers' high costs of production can usually be attributed to high transportation costs due to the inaccessibility (distance and poor road conditions) of the plantations.

The government can still do much for the tree growers in this respect. It can link the tree growers with the market. It can even provide incentives to processing firms that procure their raw materials from the agreement holders. The LGUs should give higher priority to the improvement of farm-to-market roads because they also stand to benefit if the CBFMAs and IFMAs in their areas succeed through employment opportunities, spin-off industries, and tax revenues in the case of IFMAs.

The CBFMA and IFMA holders should be encouraged to form associations that can strengthen their bargaining power with other stakeholders and with their markets. They need to strive to undergo forest certification to gain access to world markets, and undertake value-adding activities and produce products that command higher prices. The possibility of adopting an outgrower scheme should also be explored to distribute the risks that at present lie heavily on the tree growers. 


\section{Acknowledgment}

This study was funded by the Asian Development Bank (ADB) under the grant project 'Planning for Sustainability of Forests through Adaptive Co-Management' (RETA 5812) and the Center for International Forestry Research.

The authors are indebted to the following persons whose contributions made the completion of this study possible:

People at, and former staff of, CIFOR: Bruce Campbell, Christian Cossalter, Philippe Guizol, Ken MacDicken, David Kaimowitz, Julia Maturana, Rosita Go, Glen Mulcahy, Eko Prianto, Gideon Suharyanto. The external reviewers: Reed Meril (Natural Resource Management Project, USAID), Peter Moore (IUCN/WWF Forest Fires Fight), Digby Race (Australian National University), Sonja Vermeulen (IIED), and Mary Milne.

Dr. Lucrecio L. Rebugio, former Dean of the UPLB College of Forestry and Natural Resources; Dr. Rodel D. Lasco, former Director of the Environmental Forestry Program; Dr. Severo Saplaco former Director of the Institute of Renewable Natural Resources;

Forest Management Bureau Director Al Rashid H. Ishmael Al Hadj, Foresters Marcial Amaro, Jr. Domeng Bacalla, Isabel Austria, Fe Carpio, Ronnie Salac, Myla Vasquez, Nonie Tamayo, and Genalyn Dichoso of DENR Central Office; PENROs Romualdo Villador (Isabela), Honorio Toribio (Quirino), Livino Duran (Iloilo), Dionisio Molina (Capiz); CENROs Sixto Badua (Talacogon, Agusan del Sur), Jaime Ubanos (Bayugan, Agusan del Sur) and Joel Navarra (Sigma, Capiz); Forester Nelson Aguirre of CENRO Sara, Iloilo and CFPQ Project Manager Gordon Bernard Ignacio for facilitating our data collection work and for providing other important information about CBFMP, SIFMP, and IFMP;

The officers and members of Don Mariano Perez Farmers Multi-purpose Cooperative, Inc., ANAK-Jamindan and Sta. Maria-Magkalape Tree Planters Association;

Dr. Jesus Cruz, manager of Woodland Wood Products, Inc; Mr. Johnny Que, owner of Iloilo Washington Commercial and Company Forester Oscar Arias; Mr. Jose Yap, Vice PresidentOperating Unit Head and Forester Cyril Cortez of Casilayan Softwood Development Corporation;

Dr. Nathaniel Bantayan and Forester Eric Lopez of the ERSG Lab for helping us prepare the maps; Project research assistant, Rodolfo Espada, Jr., and Forester Filipina Cortezano;

And

To the others whose names escape us at the moment, THANK YOU!

December 2004 


\section{Table of Contents}

Executive summary iii

Acknowledgment $\quad v$

Annexes vii

List of Tables vii

List of Figures viii

List of Acronyms ix

Glossary $\quad$ xi

1. Introduction 1

1.1. Background and objective of the study 1

1.2. Methodology 2

a. Case study selection 2

b. Stakeholder Analysis 3

C. Financial Analysis 3

2. Government partnership initiatives in the Philippines and the case studies 4

2.1. Community Based Forest Management Program (CBFMP) 5

a. The program $\quad 5$

b. Overview of case studies 6

C. Characteristics and motivation to join the partnership schemes 9

2.2. Integrated Forest Management Program (IFMP) 10

$\begin{array}{ll}\text { a. The program } & 10\end{array}$

$\begin{array}{ll}\text { b. Overview of the case studies } & 10\end{array}$

c. General characteristics and motivation to join the partnership schemes 13

3. Initiating and implementing the government partnerships 15

3.1. Settlement of long-term land user rights/status $\quad 15$

3.2. Stages of implementation 16

3.3. The agreements 19

a. Characteristics of the agreements, rights and responsibilities 19

b. Benefit sharing agreement 23

4. Influential conditions in implementing mutually beneficial partnerships $\quad 27$

4.1. Commercial viability and financial feasibility 27

4.2. Market for timber products 33

4.3. Information sharing 35

4.4. Income diversity 35

4.5. Valuation of stakeholders' inputs 37 
4.6. Reinvestment mechanism 39

4.7. Consideration of socio-cultural conditions and needs of tree growers 41

4.8. Conflict resolution mechanism 42

4.9. Renegotiation mechanism 44

5. Conclusions and recommendations $\quad 45$

5.1. Problems and relevant recommendations for both programs 46

5.2. Community-Based Forest Management Program 48

5.3. Industrial Forest Management Program 49

$\begin{array}{ll}\text { References } & 51\end{array}$

Annexes $\quad 53$

Annex 1.The assessment guidelines (Nawir et al. 2003) 53

Annex 2. Bases and assumptions of the financial analysis 58

Annex 3. Cashflow of Don Mariano Perez Farmers Multipurpose Cooperative Inc.'s

Tree Plantation Project (PhP 000) 63

Annex 4. Cashflow of ANAK-Jamindan (PhP 000) 64

Annex 5. Cashflow of Sta. Maria-Magkalape Tree Planters Association (PhP 000) 65

\section{List of Tables}

Table 2-1. Overview of case studies: Community Based Forest Management Program (CBFMP)

Table 2-2. General characteristics of the case study areas CBFMP

Table 2-3. Overview of case studies Integrated Forest Management Program (IFMP)

Table 2-4. General characteristics of the case study areas IFMP 14

Table 3-1. Approaches in settling issues over land user rights 16

Table 3-2. Salient provisions of contracts under the Community-Based Forest Management Program and the Integrated Forest Management Program

Table 3-3. Responsibilities and incentives of a people's organisation and the Department of Environment and Natural Resources under the Community-Based Forest Management Program

Table 3-4. Responsibilities and incentives of a private company and the Department of Environment and Natural Resources under the Integrated Forest Management Program

Table 3-5. Benefit sharing arrangements of case studies 24

Table 4-1. Economic motivation of participants for joining the programs 27

Table 4-2. Financial indicators of feasibility of the case studies 29

Table 4-3. Proportion of costs for various activities (of the case studies) 31

Table 4-4. Results of the sensitivity analysis 32

Table 4-5. The mechanism to set and renegotiate the price and implications for tree growers 
Table 4-6. Income sources of the case studies 36

Table 4-7. Inputs of stakeholders in the two programs 38

Table 4-8. Reinvestment mechanisms of the case studies 41

Table 4-9. Approaches used by stakeholders to address conflicts or issues $\quad 42$

\section{List of Figures}

Figure 2-1. The case study areas of the Community Based Forest Management Project

Figure 2-2. The case study areas of the Integrated Forestry Management Project $\quad 11$

Figure 3-1. Stages of Community-Based Forest Management Program 17

Figure 3-2. Stages of Integrated Forest Management Program implementation 19 


\section{List of Acronyms}

\begin{tabular}{|c|c|}
\hline $\mathrm{ADB}$ & Asian Development Bank \\
\hline ANAK-Jamindan & Asosasyon sang Nagaproteher sang Kabukiran sa Jamindan \\
\hline $\mathrm{AO}$ & Assisting Organisation \\
\hline ARMM & Autonomous Region of Muslim Mindanao \\
\hline AWP & Annual Work Plan \\
\hline $\mathrm{BOD}$ & Board of Directors \\
\hline CADC-CBFMA & $\begin{array}{l}\text { Certificate of Ancestral Domain Claim-Community-Based Forest } \\
\text { Management Agreement }\end{array}$ \\
\hline CALC-CBFMA & $\begin{array}{l}\text { Certificate of Ancestral Land Claim-Community-Based Forest } \\
\text { Management Agreement }\end{array}$ \\
\hline CAR & Cordillera Administrative Region \\
\hline CBFMA & Community-Based Forest Management Agreement \\
\hline CBFMP & Community-Based Forest Management Program \\
\hline CDA & Cooperative Development Authority \\
\hline CDMP & Comprehensive Development and Management Plan \\
\hline CENRO & Community Environment and Natural Resources Office \\
\hline CFDF & Community Forestry Development Fund \\
\hline CFPQ & Community Forestry Program-Quirino \\
\hline $\mathrm{CO}$ & Community Organising \\
\hline CRMF & Community Resource Management Framework \\
\hline CSC & Certificate of Stewardship Contract \\
\hline CSD & Comprehensive Site Development \\
\hline CSDC & Casilayan Softwood Development Corporation \\
\hline CTF & Communal Tree Farming \\
\hline $\mathrm{DAO}$ & DENR Administrative Order \\
\hline DENR & Department of Environment and Natural Resources \\
\hline DMPFMCI & Don Mariano Perez Farmers Multi-purpose Cooperative, Inc. \\
\hline DOLE & Department of Labor and Employment \\
\hline ECC & Environmental Compliance Certificate \\
\hline EIA & Environmental Impact Assessment \\
\hline EIS & Environmental Impact Statement \\
\hline $\mathrm{EO}$ & Executive Order \\
\hline FAR & Family Approach to Reforestation \\
\hline FMB & Forest Management Bureau \\
\hline FOM & Forest Occupancy Management \\
\hline ICC & Indigenous Cultural Community \\
\hline IEE & Initial Environmental Examination \\
\hline IFMA & Integrated Forest Management Agreement \\
\hline IFMP & Integrated Forest Management Program \\
\hline IP & Indigenous Peoples \\
\hline IRR & Internal Rate of Return \\
\hline ISFP & Integrated Social Forestry Program \\
\hline ITPLA & Industrial Tree Plantation Lease Agreement \\
\hline IWC & Iloilo Washington Commercial \\
\hline
\end{tabular}


LEAF

LGU

LOI

MBTF

MOA

MOU

MPFD

NEDA

NFP

NGO

NPV

OECF

PD

PENRO

PICOP

PLA

PO

RA

RED

RENRO

RUP

SEC

SIFMA

SIFMP

SMTPA

TLA

VALUES, Inc.

WWPI
Livelihood Enhancement through Agroforestry

Local Government Unit

Letter of Instruction

Manobo Banwaon Talaandig Federation

Memorandum of Agreement

Memorandum of Understanding

Master Plan for Forestry Development

National Economic and Development Authority

National Forestation Program

Non-Government Organisation

Net Present Value

Overseas Economic Cooperation Fund

Presidential Decree

Provincial Environmental and Natural Resources Office

Paper Industries Corporation of the Philippines

Pasture Lease Agreement

People's Organisation

Republic Act

Regional Executive Director

Regional Environment and Natural Resources Office

Resource Use Plan

Securities and Exchange Commission

Socialised Industrial Forest Management Agreement

Socialised Industrial Forest Management Program

Sta. Maria Magkalape Tree Planters Association

Timber License Agreement

Visayan Association for Livelihood and Upliftment of Ecological System, Inc.

Woodland Wood Products, Inc. 


\section{Glossary}

Community Resources

Management Framework (CRMF):

Community-Based Forest Management Agreement (CBFMA):

Community-Based Forest Management Strategy (CBFMS):

Comprehensive Development and Management Plan (CDMP):

\section{Cost Benefit Analysis (CBA):}

Financial Analysis:

Integrated Forest Management Agreement (IFMA):
The document defining the terms and procedures for access, use, and protection of natural resources within the CBFMA area, which shall in all cases be consistent with the overall management strategy of the entire watershed area where the CBFM area is located, and shall be formulated by the community with the assistance of its $\mathrm{PO}$ and the DENR, LGU and/or private entities (DAO 96-29)

A production sharing agreement between the DENR and the PO that provides security of tenure and incentives to develop, utilize and manage specific portions of forestlands and pursuant to the approved CRMF (DAO 96-29)

Organised efforts by the DENR to work with communities in or near public forestlands with the intent to protect, rehabilitate, manage, conserve, and utilize the resources (DAO 96-29)

A long-term plan prepared and submitted by an IFMA holder to, and for approval by, the DENR which, among others, indicates the series of sequential or simultaneous undertakings and their schedules, in developing and managing the IFMA area, including the harvesting and utilization of the products thereof (DAO 99-53)

Evaluates a project's contribution to the development of the economy and whether the use of society's scarce resources is justified; also called Economic Analysis (Perkins, 1994)

Evaluates the commercial profitability of a project for the enterprise or agency implementing it

A production -sharing contract entered into by and between the DENR and a qualified applicant wherein the DENR grants to the latter the exclusive rights to develop, manage, protect and utilize a specified area of forestland and forest resource therein for a period of 25 years, which may be renewed for another 25 -year period. This must be consistent with the principles of sustainable development and in accordance with an approved CDMP, and under which other parties share in its produce (DAO 99-53) 
People's Organisation (PO): A group of people, which may be an association, cooperative, federation or other legal entity, established by the community to undertake collective action to address community concerns and needs and mutually share the benefits from the endeavour (DAO 96-29)

Socialised Industrial Forest Management Agreement (SIFMA):

Timber License Agreement (TLA):

Outgrower scheme:
An agreement entered into by and between a natural or juridical person and the DENR where the latter grants to the former the right to develop, utilize and manage a small tract of forestland, consistent with the principles of Sustainable Development (DAO 96-24)

Refers to a privilege granted by the State to a person to utilize forest resources within a forest with the right of possession and occupation thereof, to the exclusion of others, except the government, but with the corresponding obligations to develop, protect and rehabilitate the same in accordance with the terms and conditions set forth in the said agreement (DAO 99-53)

A partnership between two or more parties combining land, capital, management and market opportunities, formed with the intention to produce a commercial forest crop or timber in forestry p lantations based on contractual agreement (Mayers 2000) 


\section{Introduction}

\subsection{Background and objective of the study}

The total forestland area of the Philippines is $15,882,756$ ha, or about $53 \%$ of the country's total land area of 30,000,000 ha (Forest Management Bureau, 1998). Areas classified as forestlands include public and permanent forests, as well as those that have been declared as forest reserves and reservations. The country's old-growth forests are down to less than $700,000 \mathrm{ha}$, and continue to be threatened by illegal loggers and slash-and-burn farmers (locally called kaingineros).

Between 1960 and 1990, the average reforestation rate was about 15,000 ha per year. This compares poorly to the average deforestation rate of 224,000 ha per year for the period (Master Plan for Forestry Development, 1990). The big discrepancy between the deforestation and reforestation rates has brought about considerable damage to society through soil erosion silting up of rivers and floods, and revenue losses from forestland conversion to inferior uses. The Master Plan also projected the areas for tree plantation development under various schemes such as: the 1.538 million ha (2000), 2.060 million ha (2005), 2.541 million ha (2010), and 3.008 million ha (2015). The pace of plantation development, however, is much too slow.

The supply scenarios of the Master Plan for Forestry Development (1990) for different wood products failed to materialize, with actual production falling short of the projections. The Philippines' status in the world market for primary wood products has also changed from being a net exporter to a net importer. More than any indicator, this shows how much the forestry sector has suffered as a result of deforestation. Consequently, the forestry sector's contribution to the economy also decreased. Certainly, the country cannot afford to depend on importation to meet its wood requirements. The Philippine peso has weakened considerably over the past two to three years (1998-2000), and some firms that are importing their raw material requirements have found it difficult to continue their operations. Still, the demand for wood and wood-based products is expected to increase, and the government has to face this problem squarely. Unfortunately, few incentives have been given to forestry plantation development in the past because of the misconception that the country's natural forests were inexhaustible.

Since the 1970s, the government has initiated various programs in partnership with different sectors of society: private citizens/individuals, communities and the private sector, in its reforestation efforts. The latest government-initiated programs to reforest the country's denuded lands and at the same time provide for the country's wood requirements are the Community-Based Management Program (CBFMP), Socialised Industrial Forest Management Program (SIFMP), and the Integrated Forest Management Program (IFMP). The government's partners in these programs are the communities, individuals/cooperatives, and private companies, respectively. 
There have also been initiatives by the private sector to develop tree plantations. One of the pioneers in tree outgrower schemes in the Philippines was the Paper Industries Corporation of the Philippines (PICOP), a big pulp and paper producer and holder of Integrated Forest Management Agreements or IFMA (formerly concession areas under Timber License Agreements) in Mindanao.

The main objectives of the Department of Environment and Natural Resources in initiating both programs of CBFMP and IFMP can be summarised as ecological, social and economic. Ecological, because both seek to rehabilitate degraded forestlands; social, because both seek to uplift the living conditions of upland communities; and economic, because both programs are envisioned to provide employment opportunities and contribute to the supply of wood and non-wood forest products.

There have also been spontaneous efforts in the private sector to develop tree plantations on private lands. While the government does not have a formal program for this sector yet, the Department of Environment and Natural Resources issued a memorandum circular 97-11 in 1997 requiring all private tree plantation owners to register their plantations. Among others, this will facilitate the harvesting and marketing activities of the private owners later on.

The study aimed to evaluate the effectiveness of two forest management programs in the Philippines using case studies. Specifically, it sought to identify practical social and economic principles for effective forest management and to ensure a mutually beneficial partnership among the key stakeholders to develop tree plantations. The study also aimed to analyse the financial feasibility of the selected study sites.

\subsection{Methodology}

\section{a. Case study selection}

The different forest management programs in the country were identified based on the criteria of land ownership (private or state/government), and types of partner (community, individuals, families/cooperatives, and private corporations). The programs on which the study focused were chosen based mainly on the criteria that the project should have been in existence for at least three (3) years and have tree planting as one of the main activities. These criteria provided an assurance of getting meaningful information from the study sites that would be used in the analysis. As a result of this, the study sites came only from CBFMP and IFMP. All the case studies have been awarded tenurial instruments, particularly Community Based Forest Management Agreement for the people's organisations, and the Integrated Forest Management Agreement for the companies. Getting these instruments can be considered an achievement because of the requirements that have to be complied with before they are awarded.

One CBFMP area and one IFMP area were chosen for each of the three major geographical regions in the country, namely: Luzon (Region 2), Visayas (Region 6) and Mindanao (Region 13). Two of the regions where the study sites were situated, are important wood producing regions of the country. Region 2 or the Cagayan Valley Region is the second highest log- 
producing region in Luzon, while Region 13 or the Caraga Region is considered the timber corridor of the country because of its general suitability for timber production. In 1998, 73\% of the country's log production came from this region. Region 13 also has the biggest area under IFMA in the whole country. In contrast, Region 6, specifically the island of Panay, is considered a recipient of logs. As of 1998, this region did not contribute at all to the country's $\log$ production.

Lists of participants in the two schemes were obtained from the Forest Management Bureau (FMB), Department of Environment and Natural Resources (DENR). The advice of DENR was sought in identifying the specific projects to be included, considering factors like accessibility and receptiveness to this kind of study.

\section{b. Stakeholder Analysis}

The major stakeholders for the programs under focus in the study were identified and interviewed using questionnaires about the financial/economic, management, social, policy and ecological aspects of the schemes using the principles of 'mutually beneficial partnerships' as attached in Annex 1 (Nawir et al. 2003). The relationships between and among stakeholders were analysed. Secondary information was gathered from government statistical reports and other publications on tree plantations, as well as reports submitted to the DENR.

\section{c. Financial Analysis}

The data needed for the financial analysis was gathered from plans and reports submitted by the agreement holders to the DENR and from interviews. The cost and revenue information obtained from the study areas were prepared in different years. To allow comparison, these values were compounded to their Year 2000 values using the average inflation rate for the period.

The financial analysis evaluated the profitability of each case study using the net present value (NPV) and internal rate of return (IRR). An interest rate of $15 \%$, corresponding to the opportunity cost of capital, was used for the financial analysis. The discounting period corresponded to the duration of the agreement ( 25 years). The decision criterion used was to consider a project feasible if its NPV was positive and its IRR greater than the discount rate. A project with a negative NPV and an IRR less than the discount rate was considered not feasible.

The main constraint in the financial analysis was the three-month duration of this project that limited the time for data gathering and analysis. The information used for this part of the study was based mainly on the cost, yield and revenue information, provided in the agreement holders' management plans. In cases where the information was incomplete or unavailable, published results of studies that evaluated the financial feasibility of different tree species were used. The analysis only focused on the tree plantation component of the case study sites in the absence of good information for the agricultural component for most of the sites. 


\section{Government partnership initiatives in the Philippines and the case studies}

The Department of Environment and Natural Resources, particularly through its Forest Management Bureau, is the national agency that is mainly responsible for the development of tree plantations (and forestry concerns) in the Philippines (Figure 2.1). In the field, the Regional Environment and Natural Resources Office, Provincial Environment and Natural Resources Office, and Community Environment and Natural Resources Office implement its programs and projects. The Community Environment and Natural Resources Office are directly responsible for implementing the Community-Based Forest Management Program, Socialised Industrial Forest Management Program, and the Integrated Forest Management Program within its jurisdiction. It is tasked to identify potential project sites, process applications, and monitor and evaluate program implementation. The Provincial and Regional Environment and Natural Resources Offices are responsible for the programs at the provincial and regional levels, respectively, and maintain databases for each program. The Forest Management Bureau serves as the National Coordinating Office.

The participation of the local government units in various programs and projects is given utmost importance in the Philippines. The local government units include the province, which is headed by a governor; city or municipality, which is headed by a mayor; and barangay (village), the smallest local government unit, which is headed by a barangay captain. In the case studies, the local government units involved are mostly those of the municipality and the barangay.

The local government unit concerned is a major stakeholder in these programs not only because it has jurisdiction over the project site, but also because the law (Republic Act 7160) provides that it should have a share of the proceeds from the development and utilization of the national wealth. In the past, the host province, municipality and barangay did not benefit from the utilization of natural resources in their areas, primarily because the operators took their earnings with them to their city base. Logging in timber-rich provinces like Surigao and Agusan significantly contributed to the country's economic growth in the 1960s until the 1970s, yet, these provinces were neglected for some time.

The motives of the partners of the Department of Environment and Natural Resources in the two programs differ: the communities have joined the program for survival, while the companies have joined mostly for profit. The overall motives expressed by the people's organisations are common to the three case studies - the members basically want security of tenure and continuous income. The upland communities can be considered a persecuted group, having been branded before as illegal forest occupants. They are also considered to be the most important cause of forest destruction in the country, having displaced logging several decades back. This is mainly because many of the upland communities are migrants from the lowlands and knew next to nothing about sustainable upland farming when they arrived in these areas. 


\subsection{Community Based Forest Management Program (CBFMP)}

\section{a. The program}

The 25-year Master Plan for Forestry Development recommended that the communitybased forest management strategy manage, protect, rehabilitate and utilize at least four (4) million ha of forestlands. The Philippines 2000 and the Social Reform Agenda recognized the importance of empowering people and encouraging them to actively participate in forest protection and management. Consequently, Executive Order No. 263 was issued by the then President Fidel V. Ramos in 1995 "adopting community-based forest management as the national strategy to ensure the sustainable development of the country's forestland resources and as a way of providing the mechanisms for its implementation."

The Community-Based Forest Management Program formally began in 1996. Its underlying principle is "people first and sustainable forestry will follow". It seeks to address first the problem of poverty in the uplands and at the same time to involve organised communities in sustainable forest management.

The Community-Based Forest Management Program is not entirely new. It simply brought under one roof all the people-oriented forestry programs of the government, including the Integrated Social Forestry Program, Upland Development Program, Forest Land Management Program, Community Forestry Program, Low Income Upland Communities Project, Regional Resources Management Program, Integrated Rainforest Management Program, Forestry Sector Project, Coastal Environment Program, and Recognition of Ancestral Domains and Claims.

Participants of the program are provided security of land tenure through the following instruments:

- Community-Based Forest Management Agreement (CBFMA) - a production sharing agreement between the Department of Environment and Natural Resources and the participating people's organisation $(\mathrm{PO})^{1}$. It provides security of tenure and incentives for the development, utilization and management of forestlands based on the approved Community Resource Management Framework. The agreement is for duration of 25 years, renewable for another 25 years. Certificate of Stewardship Contract (CSC)- awarded to individuals or families who actually occupy or till portions of forestland pursuant to 'Letter of Instruction 1260', which created the Integrated Social Forestry Program.

- Certificate of Ancestral Domain Claim - Community-Based Forest Management Agreement (CADC-CBFMA) and Certificate of Ancestral Land Claim - Community-Based Forest Management Agreement (CALC - CBFMA) - both declare, identify and recognize the claims of indigenous Filipinos in areas within forestlands that they have traditionally possessed, occupied and used. The difference is that the CADC- CBFMA is issued to an indigenous cultural community or indigenous people, while the CALC- CBFMA is issued to an indigenous Filipino individual, family or clan.

The areas available for this program include uplands and coastal lands of the public domain. The size can be as small as one to five ha (for a Certificate of Stewardship Contract) to as big as 30,000 ha (for other types of agreement). 


\section{b. Overview of case studies}

The Community-Based Forest Management projects included in this study are those that focus on developing tree plantations. The three cases studied in this project were the Don Mariano Perez Farmers Multipurpose Cooperative, Inc. (located in Luzon), ANAK-Jamindan, Inc. (located in Visayas), and the Santa Maria Magkalape Tree Planters Association (located in Mindanao). Figure 2.1 shows the relative locations of the project sites, while Table 2.1 presents the general information about the three projects.

\section{$\underline{\text { Don Mariano Perez Farmers Multipurpose Cooperative, Inc (Don Mariano Perez PO) }}$}

The Community-Based Forest Management Agreement of the Don Mariano Perez Farmers Multipurpose Cooperative, Inc., a People's Organisation (PO), was issued on June 15, 1995. The agreement covers an area of 3,100 ha with harvestable trees in Barangay ${ }^{2}$ Don Mariano Perez, municipality of Diffun, province of Quirino, Cagayan Valley Region (Region 2). The RP-German Community Forestry Project in Quirino was highly instrumental in the awarding of the agreement to the cooperative. The cooperative's Community Resource Management Framework was affirmed on March 25, 1998, allowing it to proceed with the implementation. In its approved 1999 Annual Work Plan/Resource Use Plan, the cooperative was granted a harvestable volume of $345.114 \mathrm{~m}^{3}$ from residual forests.

The study area was previously under a Timber License Agreement. The logging activities left the area devastated, and the area's condition could deteriorate even more because of the slashand-burn activities practiced by the increasing upland population. Barangay Don Mariano Perez is $15 \mathrm{~km}$ away from the national road and the public market of the municipality of Bagabag, province of Nueva Vizcaya and the municipality of Diffun, province of Quirino. The area can be reached by a four wheel drive vehicle or motorcycle.

Table 2-1. Overview of case studies: Community Based Forest Management Program (CBFMP)

\begin{tabular}{llll}
\hline \multicolumn{1}{c}{ Descriptions } & \multicolumn{1}{c}{$\begin{array}{c}\text { Case studies } \\
\text { Don Mariano Perez }\end{array}$} & \multicolumn{1}{c}{ ANAK-Jamindan PO } & \multicolumn{1}{c}{$\begin{array}{c}\text { Sta. Maria-Magkalape } \\
\text { Association }\end{array}$} \\
\hline Location & $\begin{array}{l}\text { Municipality of Diffun, } \\
\text { Province of Quirino }\end{array}$ & $\begin{array}{l}\text { Municipality of Jamindan, } \\
\text { Province of Capiz }\end{array}$ & $\begin{array}{l}\text { Municipality of Sibagat, } \\
\text { Province of Agusan del Sur }\end{array}$ \\
\hline $\begin{array}{l}\text { Year agreement } \\
\text { was issued }\end{array}$ & 1995 & 1999 & 1999 \\
\hline $\begin{array}{l}\text { Year harvesting } \\
\text { began }\end{array}$ & 1998 & Not yet & 2000 \\
\hline Total area (ha) & 3,100 & 1,002 & 1,880 \\
\hline $\begin{array}{l}\text { Planted area (ha) } \\
\text { Timber species } \\
\text { planted/grown }\end{array}$ & $\begin{array}{l}\text { Dipterocarps, Gmelina } \\
\text { arborea }\end{array}$ & $\begin{array}{l}\text { Gmelina arborea, Swietenia } \\
\text { macrophylla, Acacia } \\
\text { mangium }\end{array}$ & $\begin{array}{l}\text { Gmelina arborea, Swietenia } \\
\text { macrophylla, } \\
\text { Acacia mangium, Pterocarpus } \\
\text { indicus }\end{array}$ \\
\hline $\begin{array}{l}\text { Non-timber species } \\
\text { planted/ grown }\end{array}$ & $\begin{array}{l}\text { Rattan, banana, citrus, } \\
\text { ginger, rice, fish (tilapia) }\end{array}$ & $\begin{array}{l}\text { Bamboo, banana, rice, } \\
\text { cassava, abaca }\end{array}$ & $\begin{array}{l}\text { Bamboo, durian, banana, } \\
\text { coconut, abaca, ginger, } \\
\text { vegetables }\end{array}$ \\
\hline
\end{tabular}


Figure 2-1. The case study areas of the Community Based Forest Management Project

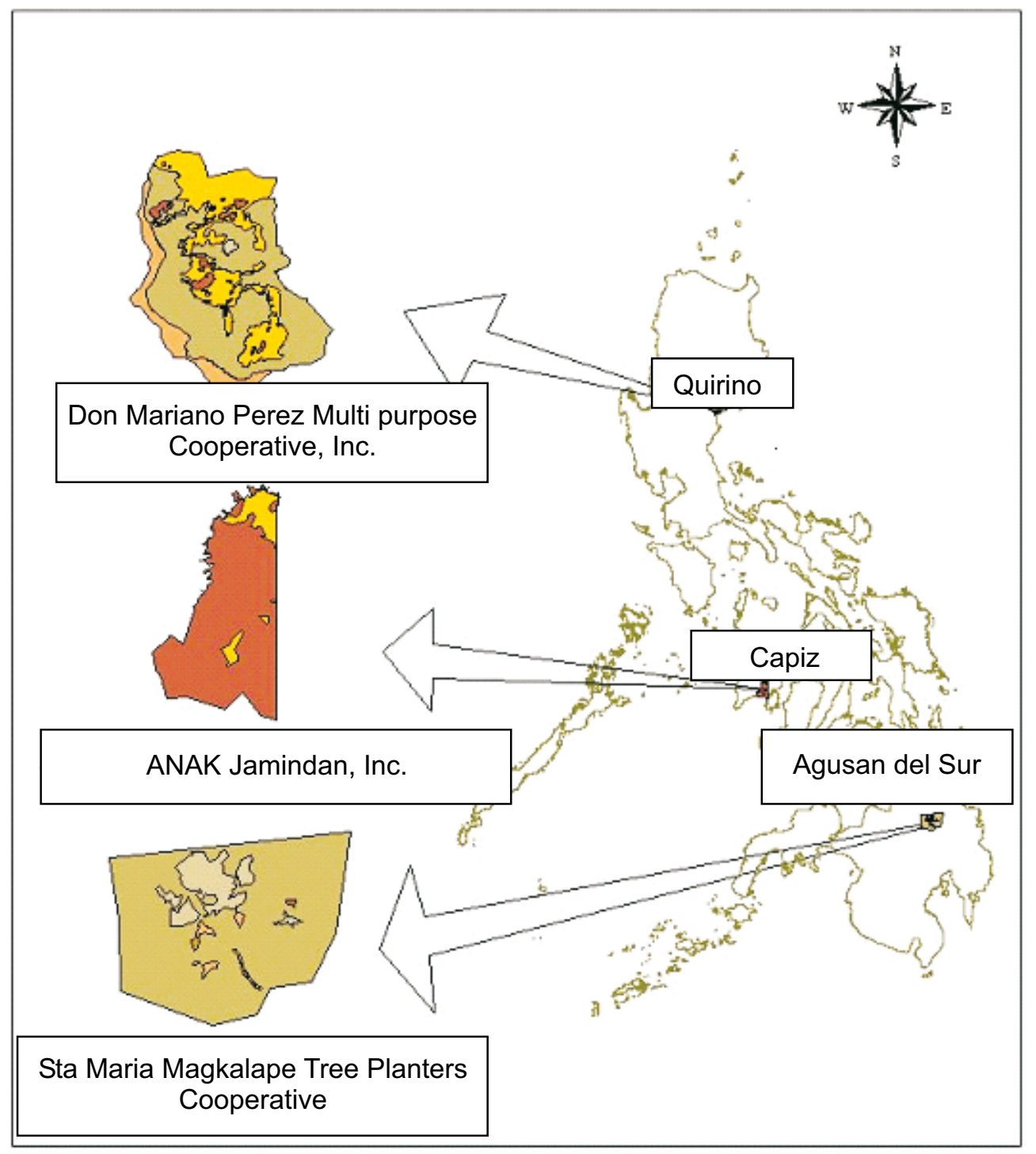

The cooperative was registered on March 24, 1994 with the Cooperative Development Authority. As of 2000, the cooperative had 135 members (109 males, 26 females). The community members in the area are generally poor. The average family income of $\$ 1,067 /$ year (US\$1 equals P45) is below the poverty line of $\$ 1,333$ set by the National Statistical Coordination Board. The community's main source of livelihood is upland farming. The main crops include banana, ginger, fruits, and rice. Since 1995, the cooperative has undertaken various activities pertaining to community forestry, sustainable agriculture, rural finance, and community infrastructure.

\section{Asosasyon sang Nagaproteher sang Kabukiran sa Jamindan (ANAK-Jamindan PO)}

ANAK-Jamindan, which stands for Asosasyon sang Nagaproteher sang Kabukiran sa Jamindan (or Association of Protectors of the Mountains of Jamindan) is a people's organisation formed in 1997. The organisation has 202 members (164 males, 38 females) coming from Barangays San Juan and Ganzon, municipality of Jamindan, province of Capiz, Western Visayas (Region 6). The residents of the two barangays belong to the Sulod Bukidnon tribe. 
The Community-Based Forest Management Agreement of ANAK-Jamindan PO was issued on February 26, 1999. The original project area was $1,002.26$ ha. The area approved in the Community Resource Management Framework was 449 ha but this was later reduced to only $126.95 \mathrm{ha}$. The reason for the reduction was the presence of titled property within the proposed project area, which was overlooked during the appraisal activity. Likewise, the project was supposed to benefit three barangays - San Juan, Ganzon and Agbun-od. However, the participation of community members from Barangay Agbun-od was not sustained because this barangay was not included in the Comprehensive Site Development activities of the project. As a result, Barangay Agbunod eventually pulled out of the project, leaving only Barangays San Juan and Ganzon. The project area itself is located in Barangay San Juan. Barangays San Juan and Ganzon are remote barangays of Jamindan, Capiz, being $17 \mathrm{~km}$ and $23 \mathrm{~km}$ from the town proper, respectively. They can be reached by walking 2 to 4 hours. The area used to be accessible to motorcycles or jeepneys, but the road has been badly eroded and is no longer passable.

There is no existing secondary forest, but there is a scattering of pioneer tree species like Nuclea batlingii, Antidesma gaesimbella, Artocarpus ovata, and Kratocselum celebicum. Saccharum spontaneum dominates the area. The tree species planted by farmers on their home lots include Gmelina arborea, Swietenia macrophylla, Pterocarpus indicus, and Acacia auriculaeformis. They also plant cassava, banana, santol (Sandoricum koetjape), jackfruit (Artocarpus heterophyllus), avocado (Persia gratissima), mango (Mangifera indica), guava (Psidium guajava), macopa (Syzigium samarangense), pandan (Pandanus sp.) and abaca (Musa textiles). The common wildlife species observed in the area are wild boar, wild chicken, monitor lizards, snakes and birds. The local communities hunt and trap wild boar and monitor lizard for meat.

\section{$\underline{\text { Sta. Maria-Magkalape Tree Planters Association (Sta. Maria-Magkalape Association) }}$}

The Community-Based Forest Management Agreement of the Sta. Maria-Magkalape Tree Planters Association, a people's organisation, was awarded on March 9, 1999. The agreement covers a total of 1,880 ha located in the barangays of Sta. Maria and Magkalape, municipality of Sibagat, province of Agusan del Sur, Caraga Region (Region 13). The cooperative was registered with the Securities and Exchange Commission and the Cooperative Development Authority on June 18, 1996. The project was established in 1995 as a Forestry Sector Project. There were 185 households in the area, of which 93 were project beneficiaries.

The project area is $22 \mathrm{~km}$ away from the town of Sibagat, $7-11 \mathrm{~km}$ from the national highway, and $4 \mathrm{~km}$ from the nearest road link. The mode of transportation is the single motorcycle (locally called "habal-habal"). The community members engage in animal and vegetable production for their livelihood. The major agricultural products are banana, coconut, corn, cassava and sweet potato. The area contains 509 ha of tree plantations that were established under the government's Forestry Sector Project. This was funded by loans from the Asian Development, popularly referred to as Loan I and Loan II. Some of the trees planted under Loan I, particularly Gmelina arborea and Leucaena leucocephala, were ready for harvesting at the time of our visit (2000).

This people's organisation can be considered more advanced than other similar organisations in the region. Its Community Resource Management Framework and Annual Work Plan 
have already been affirmed. The approved Resource Use Plan permitted the cooperative to harvest $818 \mathrm{~m}^{3}$ of plantation timber for the year 2000. It has already begun harvesting trees using selective logging.

\section{c. Characteristics and motivation to join the partnership schemes}

The general characteristics of the case study areas are summarised in Table 2.2. Most of the local inhabitants are migrants. The main reason for the immigration was the people's desire to have land that they could cultivate. These people primarily depend on the uplands for their food requirements, but do not produce much because most of the areas are degraded grasslands that are unsuitable for agriculture.

Among the three people's organisations, only Don Mariano Perez has secondary-growth or residual production forests. They have been given the right to harvest these using a selective cutting system. These forests are a major source of revenue during the early years when the plantations are not yet ready for harvest.

The most common sources of conflict among the people's organisations are perceived injustices in sharing benefits and providing employment opportunities. Conflicts over land boundaries are minimal because the community members respect the local land rights system. All the participating community members in the Community-Based Forest Management case studies are recognised people's organisations because this is a requirement of the program.

In general, local communities in upland areas have a high level of awareness about their rights, partly owing to the government's efforts to address the needs of this marginalized sector, and also because of the activities of non-government organisations (NGOs) in these areas. At times, this heightened awareness has facilitated the implementation of various projects (not only forestry-related projects) because the communities have become more open-minded. In other cases, however, it has made the communities more suspicious.

In all cases, the motivations of the people's organisations are to have a secure land tenure and continuous income. The DENR's motivation is to improve the well-being of forest dependent communities (including indigenous peoples and migrant groups) and to encourage the sustainable management of forest lands.

Table 2-2. General characteristics of the case study areas CBFMP

\begin{tabular}{|c|c|c|c|}
\hline Characteristic & $\begin{array}{l}\text { Don Mariano Perez } \\
\text { PO }\end{array}$ & Anak-Jamindan PO & $\begin{array}{l}\text { Sta. Maria-Magkalape } \\
\text { Association }\end{array}$ \\
\hline Land condition & $\begin{array}{l}\text { Logged over area with } \\
58 \% \text { secondary forest }\end{array}$ & $\begin{array}{l}\text { Degraded lands } \\
\text { dominated by } \\
\text { Saccharum spontaneum }\end{array}$ & $\begin{array}{l}61 \% \text { grasslands, with } \\
\text { harvestable plantations }\end{array}$ \\
\hline Land use pattern & $\begin{array}{l}\text { Second growth forest, } \\
\text { tree plantations, } \\
\text { rattan, agroforestry, } \\
\text { aquaculture }\end{array}$ & $\begin{array}{l}\text { Tree plantations, } \\
\text { fruit trees, bamboo, } \\
\text { agroforestry }\end{array}$ & $\begin{array}{l}\text { Tree plantations, } \\
\text { agroforestry }\end{array}$ \\
\hline Social conflicts & \multicolumn{3}{|c|}{$\begin{array}{l}\text { Minimum among members, usually over benefit sharing and employment } \\
\text { opportunities in organisations' activities }\end{array}$} \\
\hline Social organisation & \multicolumn{3}{|c|}{ Recognised People's Organisations } \\
\hline Land tenure status & \multicolumn{3}{|l|}{ CBFMA awarded } \\
\hline Individual land claims & \multicolumn{3}{|c|}{ With individual land claimants } \\
\hline
\end{tabular}




\subsection{Integrated Forest Management Program (IFMP)}

\section{a. The program}

In the second major program that the study focused on was the Integrated Forest Management Program (IFMP). The tenure instrument for this program is the Integrated Forest Management Agreement, a production sharing agreement entered into by and between the Department of Environment and Natural Resources and a qualified applicant. The agreement holder is granted the exclusive right to develop, manage, protect and utilize a specified area of forestland and forest resource therein for a period of 25 years and may be renewed for another 25-year period. The areas available for this type of agreement are grasslands, brushlands, and denuded forestlands under the jurisdiction of the Department of Environment and Natural Resources. The size ranges from 500 ha to 20,000 ha.

In the early 1980s, the government started to encourage firms to establish industrial tree plantations, but this did not really take off because most of the logging companies then had timber concessions in natural forests. In 1993, the Department of Environment and Natural Resources issued DENRAdministrative Order 93-60 that revised the regulations and guidelines for the establishment and management of industrial forest plantations and the management of residual natural forests for production purposes. Among other things, the government sought to encourage the private sector to convert the country's open and denuded lands, brushlands, and degraded residual forests, as well as the country's remaining residual forests, into sustainable production forests. This administrative order also allowed existing Timber License Agreement holders in good standing to convert to the Industrial Forest Management Agreement (which later came to be known as the Integrated Forest Management Agreement). The program seeks to address the need for a balanced, productive and efficiently functioning ecosystem; continuous supply of wood and non-wood products; and the economic wellbeing of upland people and communities dependent on forest resources.

The IFMP could not be implemented smoothly for many reasons (Pers.Com. Executives of the Philippines of Wood Producers Association, July 2000). Firstly, there are about 18 million people occupying upland areas (mostly migrants from other parts of the country) practicing shifting cultivation. Secondly, IFMA holders have to deal with the Indigenous People, who have laid claim to certain portions inside the IFMA areas, as their ancestral domains. Sometimes, the IFMA holders form partnerships with IPs and/or local people, mostly through informal agreements referring to the rights to utilise/extract non-planted timber species and NTFP on the claimant's areas. These partnership arrangements are based on a negotiable benefit sharing mechanism

\section{b. Overview of the case studies}

The Integrated Forest Management Program areas included in this study are Woodland Wood Products, Inc. or Woodland Incorporated (located in Luzon), Iloilo Washington Commercial or Iloilo Commercial (located in theVisayas), and Casilayan Softwood Development Corporation or Casilayan Corporation (located in Mindanao). All three projects have already received their Integrated Forest Management Agreements. The Casilayan Corporation has the biggest area among the three, and it was the only one that had harvested its plantations as of September 2000. The other two projects are younger, and the areas are also smaller (Figure 2.2 and Table 2.3). 
Figure 2-2. The case study areas of the Integrated Forestry Management Project

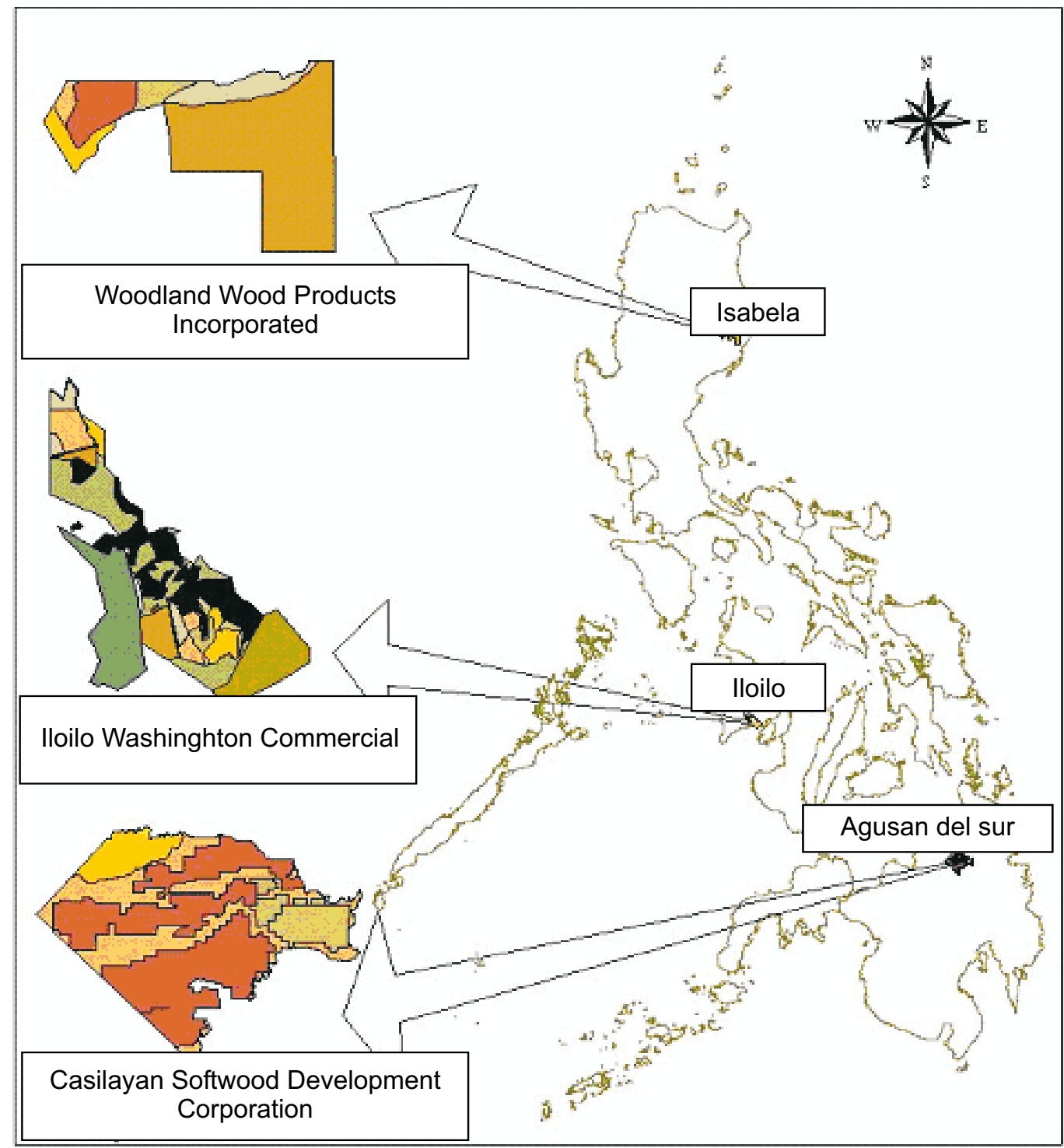

\section{Woodland Wood Products, Inc. (Woodland Incorporated)}

The Integrated Forest Management Agreement of Woodland Incorporated covers an area of 980 ha in the municipalities of Capellan, Ilagan and Tumauini, province of Isabela, Cagayan Valley Region (Region 2). The agreement was approved on January 5, 1995 and will expire on December 31, 2019. The area used to be part of the Timber License Agreement areas of Acme Plywood and Veneer Co., Inc. and the Isabela Sierra Lumber Corporation whose licenses were terminated in 1990.

The owner of the company also operates sawmill and produces housing components like doors and jambs. He was originally engaged in the furniture business and then decided to apply for an Integrated Forest Management Program mainly to assure the wood requirements of his sawmill and wood processing business, as well as for patriotic reasons. He observed that Chinese businessmen controlled the the provincial log market, and he felt that Filipinos should also be active in the market and given fairer access to the products. 
A large portion of the Integrated Forest Management Program area is classified as production residual forests that are dominated by dipterocarps. A part of the western side is under cultivation, with banana and coffee as the main crops. The area can be reached via a barangay road from San Juan, Ilagan to Capellan.

\section{Iloilo Washington Commercial (Iloilo Commercial)}

The Integrated Forest Management Agreement of Iloilo Commercial was awarded on December 13, 1994 and will expire on December 31, 2019. The 500 ha area is located in the barangays of Badiangan, Progreso and Agbobolo, all in the municipality of Ajuy, province of Iloilo in Western Visayas (Region 6).

The owner of the company and his relatives have been engaged in the furniture business for quite some time, and this is one of the reasons why he applied for an Integrated Forest Management Agreement. Presently, they are buying the wood needed for their furniture business from wood dealers.

Aside from being in the furniture business, the agreement holder is also engaged in the farming of organically grown fruits and vegetables. The main farm is in Iloilo City, but the owner has allocated 50 ha of the project area for agricultural production. This area corresponds to $10 \%$ of the total area, the maximum allowed to be set-aside for such purposes.

The major species planted are Gmelina arborea, Acacia mangium and Swietennia macrophylla. Other species that have been planted include Leucaena leucocephala, Tectona grandis, and Pterocarpus indicus but the areas planted with these species are limited. Rattan, agricultural crops and bamboo have also been planted, the latter along stream banks and creeks.

\section{Casilayan Softwood Development Corp.(Casilayan Corporation)}

The Casilayan Corporation obtained an Integrated Forest Management Agreement on July 6, 1983, which will expire on December 31, 2008. The total area under the agreement is 5,000 ha and is located in the municipality of San Luis, province of Agusan del Sur, Caraga Region (Region 13). It was previously covered by an Industrial Tree Plantation Lease Agreement.

The company is a member of the core group of the Wood Business Unit of the JAKA Group of Companies. It was organised primarily to ensure the steady supply of matchwood for its two affiliated companies, the JAKA Equities Corporation in the municipality of Magallanes, province of Agusan del Sur, and Royal Match, Inc. in Mandaue, province of Cebu.

The main species in the plantations is Endospermum peltatum which is ideal for matchwood. The company has been harvesting matchwood from its plantations since 1995 . The total area of the Endospermum peltatum plantation is more than 3,000 ha. The other species planted include Acacia mangium and Paraserianthes falcataria, but the areas planted with these species are limited. Because it is a nitrogen-fixing species, Paraserianthes falcataria is usually planted in areas where Endospermum peltatum does not thrive, to rehabilitate the soil. 
Table 2-3. Overview of case studies Integrated Forest Management Program (IFMP)

\begin{tabular}{|c|c|c|c|}
\hline \multirow[b]{2}{*}{ Description } & \multicolumn{3}{|c|}{ Case studies } \\
\hline & $\begin{array}{l}\text { Woodland } \\
\text { Incorporated }\end{array}$ & Iloilo Commercial & Casilayan Corporation \\
\hline Province & Isabela, Region 2 & Iloilo, Region 6 & $\begin{array}{l}\text { Agusan del Sur, Region } \\
13\end{array}$ \\
\hline $\begin{array}{l}\text { Year agreement was } \\
\text { issued }\end{array}$ & 1995 & 1994 & 1983 \\
\hline Year harvesting began & Not yet & Not yet & 1995 \\
\hline Total area (ha) & 980 & 500 & 5000 \\
\hline Planted area (ha) & 156 & 213 & 4,097 \\
\hline $\begin{array}{l}\text { Timber species } \\
\text { planted/grown }\end{array}$ & $\begin{array}{l}\text { Gmelina arborea, Acacia } \\
\text { mangium, } \\
\text { Swietenia macrophylla, } \\
\text { Leucaena leucocephala, } \\
\text { Eucalyptus deglupta }\end{array}$ & $\begin{array}{l}\text { Gmelina arborea, } \\
\text { Acacia mangium, } \\
\text { Swietenia macrophylla, } \\
\text { Leucaena leucocephala, } \\
\text { Eucalyptus deglupta, } \\
\text { Tectona grandis, } \\
\text { Casuarina equisetifolia, } \\
\text { Pterocarpus indicus }\end{array}$ & $\begin{array}{l}\text { Endospermum peltatum, } \\
\text { Paraserianthes falcataria }\end{array}$ \\
\hline $\begin{array}{l}\text { Non-timber species } \\
\text { planted/ grown }\end{array}$ & $\begin{array}{l}\text { Rattan, anahaw buri, } \\
\text { banana }\end{array}$ & $\begin{array}{l}\text { Marang, rattan, bamboo, } \\
\text { fruits, and vegetables }\end{array}$ & None \\
\hline
\end{tabular}

\section{c. General characteristics and motivation to join the partnership schemes}

Table 2.4 summarises the general characteristics of the Integrated Forest Management Program case study areas. Most of the local inhabitants are migrants, except for the Casilayan Corporation where the inhabitants are indigenous peoples belonging to the Manobo, Banwaon and Talaandig tribes. For the Casilayan Corporation, indigenous peoples usually harvest the trees from these forests, especially those within their claimed areas. The company has included the volume of naturally-growing trees harvested by these people in its allowable cut, although it still buys the logs from them. Among the three companies, Woodland Incorporated has second-growth or residual production forests, and has the right to harvest these during the early years before the plantations are ready for harvest.

All case studies have individual land claimants, but this is not as much a problem to the people's organisations as it is to the companies. The conflict with the claimants usually stems from their fear that they will be ejected by the companies from the lands they claim. The land claimants in two Integrated Forest Management sites have formed organisations, and have effectively represented their members and bargained with the companies over issues like land use rights and employment opportunities. The common denominator among the three Integrated Forest Management Agreement holders is that they want to secure the raw material needs of their owners' other business interests. Other reasons given were patriotism and environmental awareness. It would also be safe to say the Department of Environment and Natural Resources has succeeded in making the companies pay attention to the needs of the forest occupants in their areas, although at varying levels. In all cases, DENR' s main motivations were to have a balanced, productive and efficiently functioning forest ecosystem, continuous supply of wood and non-wood products, and economic well-being of upland people and communities dependent on forest resources. 
Table 2-4. General characteristics of the case study areas IFMP

\begin{tabular}{|c|c|c|c|}
\hline $\begin{array}{l}\text { Characteristics/ } \\
\text { motivations }\end{array}$ & Woodland Incorporated & Iloilo Commercial & Casilayan Corporation \\
\hline Land condition & $\begin{array}{l}\text { Cancelled logging } \\
\text { concession area with } 68 \% \\
\text { production residual forest }\end{array}$ & Logged over area & $\begin{array}{l}\text { Mostly with tree } \\
\text { plantations established } \\
\text { by company }\end{array}$ \\
\hline Land use pattern & $\begin{array}{l}\text { Residual forest, tree } \\
\text { plantations }\end{array}$ & $\begin{array}{l}\text { Tree plantations, } \\
\text { agriculture, livestock } \\
\text { (goats) }\end{array}$ & $\begin{array}{l}\text { Residual forest, tree } \\
\text { plantations }\end{array}$ \\
\hline Social conflicts & $\begin{array}{l}\text { Between companies and } \\
\text { claimants due to the fear of } \\
\text { being made to leave farms } \\
\text { within project area }\end{array}$ & Minimal & \\
\hline Social organisation & Claimants not organised & \multicolumn{2}{|c|}{ Claimants have organisations } \\
\hline Land tenure status & IFMA awarded & & \\
\hline Individual land claims & With individual land claimants & & \\
\hline Motivations & $\begin{array}{l}\text { - Secure raw material needs } \\
\text { of owner's business } \\
\text { - Wants presence of } \\
\text { Filipinos in wood industry } \\
\text { in the region } \\
\text { - Supply wood } \\
\text { requirements of other } \\
\text { wood processing firms }\end{array}$ & $\begin{array}{l}\text { - Secure raw material } \\
\text { needs of owner's } \\
\text { business } \\
\text { - Ecological reasons }\end{array}$ & $\begin{array}{l}\text { Secure raw material } \\
\text { needs of sister } \\
\text { company }\end{array}$ \\
\hline
\end{tabular}




\section{Initiating and implementing the government partnerships}

\subsection{Settlement of long-term land user rights/status}

The communities usually have their own system of claiming rights to land, and these are respected under the projects (Table 3.1). For ANAK-Jamindan PO, members base their land ownership claim on the area that was tilled by their forefathers. According to the assisting organisation, there is no conflict over land ownership among members because the system is recognized and respected.

Prior to the arrival of migrants from the Visayas, the Lumads (Manobos, an indigenous people) claimed the area covered by Sta. Maria-Magkalape Association as their ancestral land. When the migrants arrived in 1972, they bought the rights from the Lumads and filed tax declarations to stake their claim over the land. There are only a few Lumad families left in the area because by nature, the Lumads do not want to mingle with the migrants. At present, the more common way of acquiring rights over a piece of land is to seek the concurrence of the barangay council. The people no longer file tax declarations because the Community-Based Forest Management Agreement has given them security of tenure. The members are also allowed to continue growing agricultural crops and practice traditional farming practices, for as long as these are sustainable.

The claims of other parties, whether community members or lease holders, can create serious problems for the Integrated Forest Management Agreement holders and prevent them from carrying out their activities effectively. In the case of Woodland Incorporated, the Department of Environment and Natural Resources required the company to first secure the acceptance of the local community before the Integrated Forest Management Agreement was awarded. In the process of consultation, the concerns of community members were addressed which eventually led to the local government unit giving its stamp of approval for the establishment of the project. The local government unit made sure that the agreement holder would respect the rights of community members. Still, this has not ironed out all the disagreements between the company and the communities.

The presence of occupants in the area of Iloilo Commercial resulted in the delay of the implementation of its activities. Basically, the occupants were afraid that their landholdings or areas being claimed would be taken and planted with trees by the company. This point was the main concern of the farmer occupants to continue using the land for their own purposes even with the presence of the project. The Department of Environment and Natural Resources recognizes that it would be very difficult, if not impossible, for the farmer occupants to be ejected from the area. It eventually decided to remove the area under claim from the area awarded to Iloilo Commercial, and replaced this with other areas that were free from claims (which had not yet materialized at the time of the research team's visit). 
Table 3-1. Approaches in settling issues over land user rights

\begin{tabular}{|c|c|c|}
\hline Case study & Approach & Remarks \\
\hline Don Mariano Perez PO & $\begin{array}{l}\text { No adverse claims to land for other } \\
\text { uses }\end{array}$ & \\
\hline Anak-Jamindan PO & Inherited land ownership claim & $\begin{array}{l}\text { System is recognized and } \\
\text { respected }\end{array}$ \\
\hline $\begin{array}{l}\text { Sta. Maria-Magkalape } \\
\text { Association }\end{array}$ & $\begin{array}{l}\text { Bought land rights from Lumads } \\
\text { (indigenous peoples); } \\
\text { Filed tax declarations }\end{array}$ & $\begin{array}{l}\text { With the project, members no } \\
\text { longer file tax declarations for } \\
\text { security of tenure }\end{array}$ \\
\hline Woodland Incorporated & $\begin{array}{l}\text { Compromise with claimants arrived } \\
\text { at through public hearings }\end{array}$ & $\begin{array}{l}\text { There are still some claimants } \\
\text { who do not support the project }\end{array}$ \\
\hline Iloilo Commercial & $\begin{array}{l}\text { DENR segregated area with } \\
\text { claimants }\end{array}$ & $\begin{array}{l}\text { Resulted in delay in } \\
\text { implementing project activities }\end{array}$ \\
\hline Casilayan Corporation & $\begin{array}{l}\text { Company executed Memorandum } \\
\text { of Agreement with datus (sectoral } \\
\text { leaders of indigenous peoples) }\end{array}$ & $\begin{array}{l}\text { Company respects tribal beliefs } \\
\text { and practices }\end{array}$ \\
\hline
\end{tabular}

Casilayan Corporation has been careful in handling the indigenous peoples in the area. Since parts of the area have claims by datus (sectoral leaders of indigenous peoples), the company has executed Memoranda of Agreement with these datus. The company also recognizes the tribal practices and beliefs of the indigenous peoples. For example, offerings are made first before the trees are harvested or before areas are developed. The indigenous practices and beliefs are likewise taken into consideration in settling feuds. The indigenous peoples in the area are allowed by the company to continue their hunting and gathering activities thereby guaranteeing their rights even in areas under lease to the private sector.

\subsection{Stages of implementation}

The implementation of the Community-Based Forest Management Program is carried out in four stages as shown in Figure 3.1.

The first stage is the preparatory stage, and includes the following activities:

- Information, education and communication campaigns

- Establishment of institutional linkages

- Identification and selection of Community-Based Forest Management Program areas

The second stage is the people's organisation formation and diagnostic stage. This is where local communities are encouraged to participate in the program, and the people's organisation is formed or strengthened if there is already an existing organisation. Community organising is usually handled by a non-government organisation, referred to as an assisting organisation. The assisting organisations of ANAK-Jamindan PO and the Sta. Maria-Magkalape Association are PROCESS Foundation-Panay, Inc. and the Visayan Association for Livelihood and Upliftment of Ecological System, Inc. On the other hand, the Don Mariano Perez PO was assisted by the Community Forestry Program-Quirino. 
Figure 3-1. Stages of Community-Based Forest Management Program

\begin{tabular}{|c|c|c|c|}
\hline $\begin{array}{l}\text { Preparatory } \\
\text { - Information, } \\
\text { education and } \\
\text { communication } \\
\text { campaigns } \\
\text { (DENR, LGU) } \\
\text { - Institutional } \\
\text { linking (DENR, } \\
\text { LGU, } \\
\text { government } \\
\text { agencies) } \\
\text { - Identification of } \\
\text { CBFMP area } \\
\text { (DENR, LGU, } \\
\text { local community) }\end{array}$ & $\begin{array}{l}\text { PO Formation and } \\
\text { Diagnosis } \\
\text { - Application to } \\
\text { participate in } \\
\text { CBFMP } \\
\text { (CENRO) } \\
\text { - Community } \\
\text { appraisal and PO } \\
\text { formation } \\
\text { (CENRO,LGU) } \\
\text { - Application for } \\
\text { CBFMA } \\
\text { - Approval and } \\
\text { issuance of } \\
\text { CBFMA }\end{array}$ & $\begin{array}{l}\text { Planning } \\
\text { Formulation of } \\
\text { Community } \\
\text { Resource } \\
\text { Management } \\
\text { Framework } \\
\text { (CRMF), Resource } \\
\text { Use Plan (RUP), } \\
\text { Annual Work Plan } \\
\text { (AWP) } \\
\text { (implemented by } \\
\text { PO with DENR, } \\
\text { LGU, other } \\
\text { sectors) }\end{array}$ & $\begin{array}{l}\text { Implementation } \\
\text { - Review and revision } \\
\text { of PO's constitution } \\
\text { and by-laws } \\
\text { - Sourcing of financial } \\
\text { and technical } \\
\text { assistance } \\
\text { - Mobilizing } \\
\text { workgroups } \\
\text { - Strengthening } \\
\text { organizational and } \\
\text { entrepreneurial skills } \\
\text { - Market linkage } \\
\text { - Monitoring and } \\
\text { evaluation } \\
\text { - Membership and } \\
\text { leadership skills } \\
\text { development }\end{array}$ \\
\hline
\end{tabular}

The existing conditions (social, economic, natural resources, others) needed for planning are likewise identified. This stage culminates with the organisation's application to obtain a Community-Based Forest Management Agreement. The approving authority of the Department of Environment and Natural Resources depends on the size of the area being applied for, as follows:

\begin{tabular}{ll}
\hline Area & Approving Authority \\
\hline Up to 5,000 ha & $\begin{array}{l}\text { Provincial Environment and Natural Resources } \\
\text { Officer }\end{array}$ \\
\hline More than 5,000 ha to 15,000 ha & Regional Executive Director \\
\hline More than 15,000 ha to 30,000 ha & Undersecretary \\
\hline More than 30,000 ha & Secretary \\
\hline
\end{tabular}

The decentralization of the authority to approve applications for Community-Based Forest Management Agreements for areas less than 15,000 ha works in favour of the applicants. Most of the latter operate on a small-scale. Some of them may not have the means to follow up their applications all the way to the Central Office, based in Metro Manila. 
Under the third stage, which is the planning stage, the people's organisation prepares the Community Resource Management Framework ${ }^{3}$, Resource Use Plan ${ }^{4}$ and Annual Work Plan $^{5}$ with the assistance of the Department of Environment and Natural Resources, local government unit (LGU), and other relevant sectors (e.g., NGOs). All the people's organisations revealed that they were heavily involved in the planning stage, including the preparatory activities like the 'resource inventory'.

The last stage is the implementation stage where the various activities in the Community Resource Management Framework, Resource Use Plan and Annual Work Plan are carried out. It is stated in the policy that the outcomes of the implemented activities for each year should be reviewed and taken into consideration when putting together the following year's Annual Work Plan.

It can be said that the Department of Environment and Natural Resources has a higher level of involvement in the formulation of the people's organisations' plans than that of the companies, primarily because the latter are expected to be technically equipped in tree plantation development and forest management in general. The government has also included in the implementation stage of the Community-Based Forest Management Program activities that are not actually related to plantation development, but which have been identified as critical in truly empowering the people's organisations. These include:

- Review and revision of the people's organisation's constitution and by-laws

- Sourcing of funds and technical assistance

- Mobilizing workgroups

- Strengthening organisation and entrepreneurial skills

- Linking and transacting with markets

- Monitoring and evaluation

- Conducting membership and leadership skills development

If these activities are properly conducted, the chances of success are high. However, there have been reports that some of the activities have been mishandled, particularly training activities to strengthen the organisational, leadership, technical and entrepreneurial skills. In one of the study areas, a respondent claimed that most of the training programs were conducted by the assisting organisation only when the billing period approached. If true, this would have made the training ineffective because it would have been difficult for the participants to internalise so many different concepts in a span of about two weeks.

The government should thus be more discriminating in evaluating the performance of assisting organisations in capacity building. It should not only look at the number of training programs conducted, but also when and how these were implemented.

For the Integrated Forest Management Program, it is also the Community Environment and Natural Resources Office (CENRO) that accepts and processes applications (Figure 3.2). Filipino citizens of legal age or duly registered corporations, partnerships, associations or cooperatives with at least $60 \%$ of capital owned and controlled by Filipino citizens are qualified to apply for an Integrated Forest Management Agreement. Furthermore, applicants are required to show proof of an environmental management record and a community relations record. 
The CENRO then prepares the agreement before endorsing and sending the application to the Provincial Environment and Natural Resources Office (PENRO), Regional Environment and Natural Resources Office (RENRO) and the Forest Management Bureau (FMB), which are tasked with reviewing and evaluating the agreement and application documents. However, the final decision as to whether the application is approved or denied lies with the Secretary of the Department of Environment and Natural Resources. Only the Secretary has the authority to approve such applications because the large scale and commercial nature of operations require a careful review of the merits of the applications.

Figure 3-2. Stages of Integrated Forest Management Program implementation

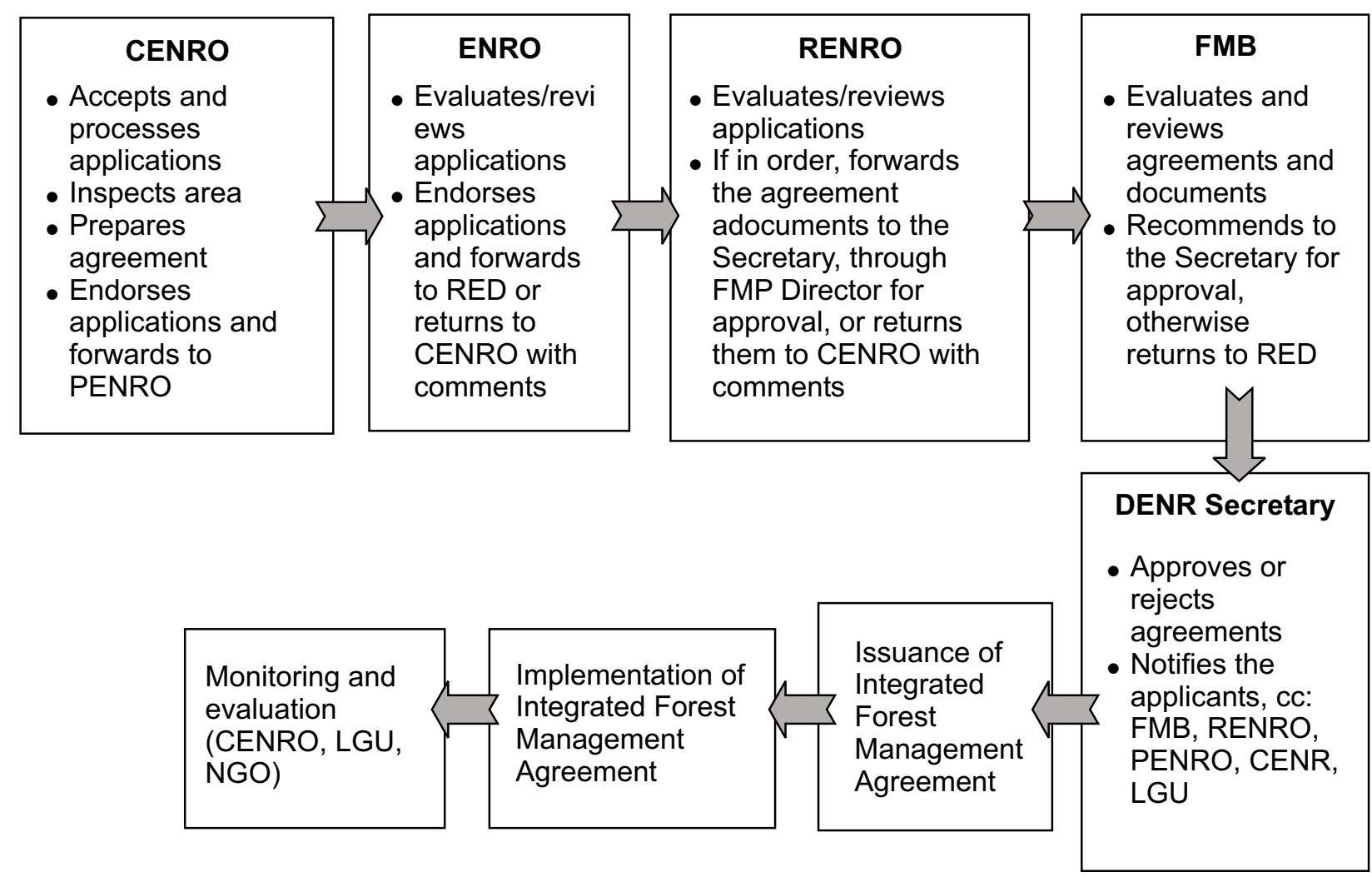

Notes:

CENRO: Community Environment and Natural Resources Office

PENRO: Provincial Environment and Natural Resources Office

LGU: Local Government Unit

RENRO: Regional Environment and Natural Resources Office

FMB: $\quad$ Forest Management Bureau

RED: $\quad$ Regional Executive Director

\subsection{The agreements}

\section{a. Characteristics of the agreements, rights and responsibilities}

The contracts for the Community-Based Forest Management Agreement and the Integrated Forest Management Agreement follow a standard format provided by the Department of Environment and Natural Resources. The salient provisions of the two agreements are summarised in Table 3.2, while the rights and responsibilities of the major stakeholders are provided in Tables 3.3 and 3.4 . 
For the Community-Based Forest Management Program, it is only the Certificate of Stewardship Contract that can be transferred or sold, while the Community-Based Forest Management Agreement, Certificate of Ancestral Domain Claim-CBFMA and Certificate of Ancestral Land Claim of the CBFMA are non-transferable. The Certificate of Stewardship Contract is an instrument from the Integrated Social Forestry Program of the 1980s. The contract guarantees land tenure for 25 years. As such, the provisions of this contract, including the transferability clause, still remain in effect. The three other instruments that are non-transferable were created under the Community-Based Forest Management Program in 1996.

The Integrated Forest Management Agreement, however, maybe transferred, exchanged, or sold. A new provision of DENR Administrative Order 99-53 allows Integrated Forest Management Agreement holders to transfer developed plantations that are three years old or older to cooperatives upon fair compensation. With this arrangement, cooperatives will not have to concern themselves with tree plantation establishment, which they may not have the technical capacity to undertake. This will now be the concern of Integrated Forest Management Agreement holders who have been involved in tree plantation development for some time, many of whom are also in the wood processing business. If this new scheme succeeds, it will improve the local wood supply and will benefit both the cooperatives (in terms of revenues from wood harvests) and the Integrated Forest Management Agreement holders and wood processing industry (in terms of assured raw material supply).

Under the two programs, timber and non-timber plantation products are exempt from forest charges. The agreement holders only pay the required forest charges if they harvest naturally growing tree species in their areas. Also, logs produced from plantations are exempt from the log export ban, which is being applied to logs harvested from natural forests. The foreign exchange earnings of the forestry sector decreased significantly as a result of the ban, but these may pick up because of this incentive.

Table 3-2. Salient provisions of contracts under the Community-Based Forest Management Program and the Integrated Forest Management Program

\begin{tabular}{lll}
\hline Provision & $\begin{array}{l}\text { Community-Based Forest } \\
\text { Management Program }\end{array}$ & $\begin{array}{l}\text { Integrated Forest Management } \\
\text { Program }\end{array}$ \\
\hline Contract period & $\begin{array}{l}25 \text { years, renewable for another 25 } \\
\text { years }\end{array}$ & $\begin{array}{l}25 \text { years, renewable for another } \\
25 \text { years }\end{array}$ \\
\hline Responsibilities & Responsibilities of the people's & Responsibilities of the \\
& organisation and the Department of & company and the Department \\
Environment and Natural Resources & of Environment and Natural \\
are enumerated & Resources are \\
& & enumerated \\
\hline Transfer mechanism & Certificate of Stewardship Contract & May be transferred, exchanged, \\
& maybe transferred, sold or conveyed & sold or conveyed \\
& to another project participant & \\
Community-Based Forest & \\
Management Agreement, & \\
& Certificate of Ancestral Domain & \\
Claim-CBFMA, Certificate of & \\
Ancestral Land Claim-CBFMA are & \\
& non-transferable & \\
\hline
\end{tabular}




\begin{tabular}{lll}
\hline Provision & $\begin{array}{l}\text { Community-Based Forest } \\
\text { Management Program }\end{array}$ & $\begin{array}{l}\text { Integrated Forest Management } \\
\text { Program }\end{array}$ \\
\hline $\begin{array}{l}\text { Grounds for suspension or } \\
\text { cancellation }\end{array}$ & $\begin{array}{l}\text { Non-compliance with terms and } \\
\text { conditions of the agreement }\end{array}$ & $\begin{array}{l}\text { If an agreement is obtained } \\
\text { through fraudulent means or } \\
\text { violation of terms and conditions } \\
\text { of the agreement }\end{array}$ \\
\hline Appeals & $\begin{array}{l}\text { Can appeal a decision within 30 } \\
\text { days of receipt of a cancellation or } \\
\text { suspension notice }\end{array}$ & $\begin{array}{l}\text { Can appeal a decision within 30 } \\
\text { days of receipt of a cancellation } \\
\text { or suspension notice }\end{array}$ \\
\hline
\end{tabular}

Table 3-3. Responsibilities and incentives of a people's organisation and the Department of Environment and Natural Resources under the Community-Based Forest Management Program

\begin{tabular}{|c|c|c|}
\hline \multicolumn{2}{|c|}{ Responsibilities } & Incentives \\
\hline $\begin{array}{l}\text { Department of Environment } \\
\text { and Natural Resources }{ }^{1}\end{array}$ & People's Organisation & People's Organisation \\
\hline $\begin{array}{l}\text { - Protect and ensure the } \\
\text { exclusive occupation and } \\
\text { use of the forestland and } \\
\text { resources covered by } \\
\text { Community-Based Forest } \\
\text { Management Agreement by } \\
\text { the community } \\
\text { - Provide the people's } \\
\text { organisations with technical } \\
\text { assistance in preparing, } \\
\text { updating and implementing } \\
\text { plans } \\
\text { - Deputize qualified people's } \\
\text { organisation members as } \\
\text { Environment and Natural } \\
\text { Resources Officers } \\
\text { - Exempt Community- } \\
\text { Based Forest Management } \\
\text { Agreement area if province } \\
\text { is placed under logging } \\
\text { moratorium }\end{array}$ & $\begin{array}{l}\text { - Develop and implement } \\
\text { equitable benefit-sharing } \\
\text { arrangements among its } \\
\text { members } \\
\text { - Protect, rehabilitate and } \\
\text { conserve the natural } \\
\text { resources in the area and } \\
\text { assist the government in } \\
\text { the protection of adjacent } \\
\text { forestlands } \\
\text { - Develop and enforce } \\
\text { policies pertaining to the } \\
\text { rights and responsibilities } \\
\text { of its members and the } \\
\text { accountability of its leaders } \\
\text { - Develop equitable } \\
\text { mechanisms for addressing } \\
\text { conflicts } \\
\text { - Be transparent and promote } \\
\text { participatory management } \\
\text { and consensus building in all } \\
\text { activities and endeavours } \\
\text { - Pay forest charges for timber } \\
\text { and non-timber products not } \\
\text { harvested from plantations } \\
\text { and other fees and taxes } \\
\text { required by the government } \\
\text { - Undertake other } \\
\text { responsibilities agreed to in } \\
\text { the Community-Based Forest } \\
\text { Management Agreement }\end{array}$ & $\begin{array}{l}\text { - Occupy, possess, utilize and } \\
\text { develop forestlands and the } \\
\text { resources therein, including } \\
\text { introduced improvements within } \\
\text { the area } \\
\text { - Allocate among members } \\
\text { and enforce rights to use and } \\
\text { sustainably manage forestland } \\
\text { resources } \\
\text { - Be exempted from paying rent for } \\
\text { the use of the area } \\
\text { - Be exempted from paying forest } \\
\text { charges on timber and non- } \\
\text { timber products from plantations } \\
\text { - Be properly informed of and } \\
\text { consulted on all government } \\
\text { projects in the area } \\
\text { Be given preferential access by } \\
\text { the Department of Environment } \\
\text { and Natural Resources to available } \\
\text { assistance for plan development } \\
\text { and implementation } \\
\text { - Receive all income and proceeds } \\
\text { from the utilization of forest } \\
\text { resources within the area, subject } \\
\text { to the provisions of the National } \\
\text { Integrated Protected Areas } \\
\text { System Law } \\
\text { - Enter into agreement or contracts } \\
\text { with private or government } \\
\text { entities for the development of } \\
\text { the whole or portions of the area }\end{array}$ \\
\hline
\end{tabular}

Note: ${ }^{1}$ Performed by different offices of the Department of Environment and Natural Resources 
Table 3-4. Responsibilities and incentives of a private company and the Department of Environment and Natural Resources under the Integrated Forest Management Program

\begin{tabular}{|c|c|c|}
\hline \multicolumn{2}{|c|}{ Responsibilities } & Incentives \\
\hline $\begin{array}{l}\text { Department of Environment } \\
\text { and Natural Resources }{ }^{1}\end{array}$ & Private company & Private company \\
\hline $\begin{array}{l}\text { - Make available to Integrated } \\
\text { Forest Management } \\
\text { Agreement holders } \\
\text { information about the land, } \\
\text { resources and dependent } \\
\text { communities within or } \\
\text { adjacent to the area } \\
\text { - Ensure compliance with } \\
\text { provisions of the plan, } \\
\text { environmental requirements } \\
\text { and other pertinent rules and } \\
\text { regulations } \\
\text { - Assist agreement holder and } \\
\text { host communities develop and } \\
\text { implement mutually beneficial } \\
\text { agreements } \\
\text { - Not alter or modify boundaries } \\
\text { or legal status of area under } \\
\text { agreement } \\
\text { - Promote/approve joint } \\
\text { venture, financing and/or } \\
\text { securitization schemes to } \\
\text { support development of } \\
\text { agreement area }\end{array}$ & $\begin{array}{l}\text { - Delineate and mark on the } \\
\text { ground the agreement area } \\
\text { boundary } \\
\text { - Submit plan and Initial } \\
\text { Environmental Examination } \\
\text { within } 1 \text { year after agreement is } \\
\text { awarded } \\
\text { - Submit within } 1 \text { year and every } 5 \\
\text { years thereafter up-to-date aerial } \\
\text { photos or landsat imageries of } \\
\text { area } \\
\text { - Implement environmental } \\
\text { mitigation/enhancement } \\
\text { measures } \\
\text { - Plant principally timber producing } \\
\text { species } \\
\text { - Convert degraded residual natural } \\
\text { forest into a productive state } \\
\text { using prescribed methods } \\
\text { - Manage and protect production } \\
\text { residual natural forests } \\
\text { - Reforest open/denuded lands } \\
\text { within protection forestlands and } \\
\text { within } 20 \text { m from both sides of } \\
\text { river banks } \\
\text { - Protect and conserve unique, rare } \\
\text { and endangered flora and fauna } \\
\text { and roadlands } \\
\text { - Submit to the Department } \\
\text { of Environment and } \\
\text { Natural Resources Annual } \\
\text { Accomplishment Report }\end{array}$ & $\begin{array}{l}\text { - May interplant secondary } \\
\text { - Shaps between trees } \\
\text { to harvest, sell and utilize } \\
\text { planted trees and crops } \\
\text { - Can export logs, lumber } \\
\text { and other forest products } \\
\text { harvested from plantations } \\
\text { - Plantation products shall be } \\
\text { exempt from forest charges } \\
\text { - Relevant incentives under } \\
\text { the Omnibus Investment } \\
\text { Code and those enumerated } \\
\text { in Presidential Decree } 705 \\
\text { (Revised Forestry Code of } \\
\text { the Philippines) } \\
\text { - Can transfer developed } \\
\text { plantations at least } 3 \text { years } \\
\text { old to a cooperative upon } \\
\text { fair compensation or } \\
\text { payment } \\
\text { - Use stable plantation crops } \\
\text { at least three years old as } \\
\text { collateral or security for } \\
\text { loans } \\
\text { - Apply for additional area } \\
\text { or new/another Integrated } \\
\text { Forest Management } \\
\text { Agreement with satisfactory } \\
\text { performance }\end{array}$ \\
\hline
\end{tabular}

Note: 'Performed by different offices of the Department of Environment and Natural Resources

Community-Based Forest Management Agreement holders are exempt from paying land rent (DAO 96-29), as well as administrative fees like application, license/permit, service, rental, and other fees. People's organisations represent economically disadvantaged communities, and requiring them to pay such fees could render their operations unprofitable.

Participants in both programs are allowed to interplant or devote a part of their areas to agricultural crops (maximum of $10 \%$ of the total area for the Integrated Forest Management Agreement). Tree growers thus have a source of income during the years when they cannot harvest the trees. The companies can use this incentive to their advantage, not necessarily to produce agricultural crops themselves (as in the case of Iloilo Commercial) but to involve 
the communities living within the area to do so (for Woodland Incorporated and Casilayan Corporation). This has improved the relationship between the companies and their host communities because the latter will not be totally deprived of what could be their main source of livelihood.

The Integrated Forest Management Agreement and the improvements thereon (e.g. stable plantation crops) can be used as collateral for loans. However, not many agreement holders have availed themselves of this incentive, mainly because lending institutions are not keen on extending loans of this nature. This resistance can be attributed to the risks involved in and the long gestation period of tree plantations. Paying the loans can be difficult for tree growers because tree plantations do not provide annual incomes, whereas loans have to be paid yearly, if not monthly.

\section{b. Benefit sharing agreement}

The direct benefits arising from a Community-Based Forest Management Agreement are shared by the people's organisation (the organisation as a whole and its members) and the Department of Environment and Natural Resources. In the case where the people's organisation will harvest government-owned forest plantations inside Community-Based Forest Management areas, it should enter into a production sharing arrangement with the government as provided by DENR Administrative Order 98-43. Government-owned plantations include:

- Reforestation/forest plantation projects administered/established by the Department of Environment and Natural Resources

- Reforestation/forest plantations established by Timber License Agreement holders and other permit holders

- Plantations established by the Integrated Forest Management Program, Socialised Industrial Forest Management Program, Industrial Tree Plantation, Community-Based Forest Management Agreement and other tenure instrument holders that have been cancelled for various reasons

- Reforestation or plantation projects established with government funds.

The benefit-sharing scheme from the utilization of government-owned forest plantations is provided in Table 3.5. The government basically seeks to recover the funds it allocated for community organising and comprehensive site development, so that it can use this to finance other similar projects. There is an on-going review of when the government should get a share of the people's organisations' incomes, because this is not clearly stated in the policy.

The people's organisations are allowed to allocate their net incomes in a way that will be most beneficial to them. For example, Don Mariano Perez PO appropriated 20\% of its net income from its lumber operations in 1999 for road construction and maintenance. This shows that the organisation is willing to assist the government because it recognizes the urgent need for good roads. Waiting for the government to provide funds for this can take a long time. The local government of the province of Quirino supported the organisation by providing construction equipment. 
Table 3-5. Benefit sharing arrangements of case studies

\begin{tabular}{|c|c|c|}
\hline Case study & Benefit sharing arrangement & Remarks \\
\hline CBFMP & $\begin{array}{l}\text { Gross revenues sharing varies from } 70-75 \text { percent } \\
\text { goes to } \mathrm{PO} \text {, and } 30-25 \text { percent goes to DENR }\end{array}$ & \\
\hline $\begin{array}{l}\text { Don Mariano Perez } \\
\text { PO }\end{array}$ & $\begin{array}{l}\text { From net income, } \\
\text { - } 30 \% \text { - members' dividends } \\
\text { - } 30 \% \text { - general reserve fund for reforestation } \\
\text { and protection } \\
\text { - } 20 \% \text { - community development fund for road } \\
\text { construction and maintenance, etc. } \\
\text { - } 10 \% \text { - education and training fund } \\
\text { - } 10 \% \text { - local trust fund }\end{array}$ & \\
\hline Anak-Jamindan PO & $\begin{array}{l}\text { From income share, } \\
\text { - } 10 \% \text { - general trust fund } \\
\text { - } 65 \% \text { - organisation }\end{array}$ & $\begin{array}{l}\text { Organisation share will be used } \\
\text { to finance livelihood activities }\end{array}$ \\
\hline $\begin{array}{l}\text { Sta. Maria- } \\
\text { Magkalape } \\
\text { Association }\end{array}$ & $\begin{array}{l}\text { From net income, } \\
\text { - } 60 \% \text { - land claimant } \\
\text { - } 40 \% \text { - organisation }\end{array}$ & $\begin{array}{l}\text { Organisation share will be used } \\
\text { to develop other plantations } \\
\text { and finance livelihood activities }\end{array}$ \\
\hline IFMP & $\begin{array}{l}\text { Negotiated between DENR and company based } \\
\text { on: } \\
\text { - Cost of plantation establishment, protection, } \\
\text { management, infrastructure, harvesting and } \\
\text { mitigating measures } \\
\text { - Fixed assets, equipment and machinery related } \\
\text { to plantation development and harvest } \\
\text { - Kind, value and fair market prices of } \\
\text { - harvestable products } \\
\text { - Eariations in interest rate and foreign exchange } \\
\text { - development } \\
\text { - Forest charges and taxes paid } \\
\text { - Profit and risk margin }\end{array}$ & $\begin{array}{l}\text { - Provides employment for local } \\
\text { communities } \\
\text { - Provides social services } \\
\text { - Maintains roads }\end{array}$ \\
\hline
\end{tabular}

ANAK-Jamindan PO plans to allocate $10 \%$ of its 75 percent income share from the tree plantations to the general trust fund, while the remaining 65 percent will go to the association. The people's organisation will use the portion of this 65 percent to finance its livelihood activities like the mini-rice mill, buy-and-sell, and providing its members with planting materials. The people's organisation will not receive a share of the member's incomes from their agricultural crops, except payment for whatever planting materials it provides its members. Neither will it get a share from those trees that were planted by the members themselves. These trees will be inventoried to protect the members' rights to them.

The Sta. Maria-Magkalape Association's net revenue is shared between the claimant (who gets $60 \%$ ) and the people's organisation (which gets $40 \%$ ). The claimant refers to the people's organisation member from whose claimed land the trees were harvested. The $40 \%$ people's organisation share will be used to develop other plantations and livelihood opportunities like abaca plantations.

As mentioned earlier, the sharing is based on gross sales, and this can be considered both an advantage and a disadvantage. It is an advantage because it forces the people's organisation to be efficient so it will have a positive net income after the government's $12.5 \%$ share and the CBFMP fund's $12.5 \%$ share of the gross are deducted. Even if the people's organisation incurs 
high production costs that result in losses, the shares of the government and the CBFMP fund are assured.

On the other hand, keeping the costs to a minimum can be a tall order for the people's organisations because of high production and transportation costs. It is for this reason that as of early 2001, the Sta. Maria-Magkalape Association decided to cease its operations because it could no longer afford to pay the government share based on its gross sales. As implemented, the government had a share of the organisation's income even when it processed the logs, say to lumber. As such, the government's share became higher as the organisation undertook value-added processing. This is not fair because the government no longer has an input in the organisation's processing activities after the logs have been produced.

Thus, it may be more just to base the benefit sharing on the stumpage price of timber rather than gross income, which has been broadly interpreted to be the income to the organisation, will derive from the last product it sells. However, this may also result in inefficiency, because the tree growers may claim very high production costs so as to drive the stumpage value down (possibly even to zero).

The applicant and the Department of Environment and Natural Resources, taking into consideration the factors enumerated in Table 3.5, negotiate the government's share on the profits from Integrated Forest Management project. The government's share forms part of the terms of the Integrated Forest Management Agreement, but this was not explicitly mentioned in the agreement documents of the three case studies.

Local community members can also benefit from the presence of the Integrated Forest Management project in their area. The members can sell planted trees to the agreement holder. For example, the Casilayan Corporation allows the indigenous peoples to cut trees from the residual forests that are within their claimed areas. The harvesting of these trees has already been incorporated in the company's approved plan. The indigenous peoples then sell these logs, as well as those harvested from their planted trees, to the company. The price at which they sell is negotiated between the Association Chairman and the company. The indigenous peoples have information about the prices of wood in Butuan City, but they find it more convenient to sell their products to the company.

The agreement holder is also encouraged to employ local community members whenever possible. Casilayan Corporation, the biggest of the three Integrated Forest Management Program study sites, significantly contributes to employment in the area. Its workforce consists of 80 personnel, 13 of whom are indigenous peoples working as concession guards. The company offers better wage rates to its workers compared to other Integrated Forest Management Projects in the area, a claim that was confirmed by the Community Environment and Natural Resources Officer of Talacogon. As a result of their employment, the community members' incomes have significantly increased. Before, they did not have a regular source of income.

The concession guards hired by the company are sectoral datus or chieftains who have existing claims over certain portions of the Integrated Forest Management Program area as their ancestral land. The company has been successful in impressing upon the datus that what they are receiving are not dole-outs but salaries earned in exchange for the forest protection 
activities they conduct in the area. This is important because it discourages the poor attitude of expecting to receive money without doing anything. In other words, the datus are aware that they have to do their share in the management and protection of the project area also.

As part of their responsibilities, the Integrated Forest Management Agreement holders have helped construct and maintain roads within their areas. The community members use these roads to transport their agricultural produce to market. The local government units also benefit from the presence of the Integrated Forest Management projects through the social services that the companies provide in terms of medical and dental assistance, transportation assistance, and maintenance of roads and bridges within the area. Iloilo Commercial also extends credit services to the community members who are employed by the company selling them rice and groceries, the cost of which is deducted from their salaries. It also provides fertilizers that the farmers repay with fertilizers interest-free. Casilayan Corporation shoulders part of the salaries extended to the teacher employed at the Datu Sandigan Primary School and another teacher in Laminga High School. 


\section{Influential conditions in implementing mutually beneficial partnerships}

\subsection{Commercial viability and financial feasibility}

There are provisions in the policies governing the two programs that promote their financial viability. For the Community-Based Forest Management Program, the people's organisations are allowed to engage in livelihood activities other than tree farming, e.g. livestock production, agricultural crops, and rental of farm implements (Table 4.1).

The people's organisation can also utilize naturally growing or planted forest resources under its Resource Use Plan so it can generate start-up capital for its livelihood and other activities (Department of Environment and Natural Resources Administrative Order 2000-29). This is an important provision because the people's organisations usually do not have funds when they begin their operations. Thus, they will not have to borrow money from lending institutions early on. However, the provision could be abused. The Department of Environment and Natural Resources has received reports that some people's organisations use their funds for their Resource Use Plans for illegal logging. In other cases, the people's organisations lose interest to continue other activities after they have harvested the timber.

Table 4-1. Economic motivation of participants for joining the programs

\begin{tabular}{|c|c|c|}
\hline People's Organisation & Company & DENR \\
\hline $\begin{array}{l}\text { - Can engage in livelihood } \\
\text { activities for early and } \\
\text { continuous income } \\
\text { - Can utilize naturally growing } \\
\text { or planted forest resources } \\
\text { - Food requirements are met } \\
\text { - Improved accessibility to } \\
\text { market and town proper } \\
\text { - Avail of loan services }\end{array}$ & $\begin{array}{l}\text { - Supply raw wood material } \\
\text { to owners' other business } \\
\text { interests } \\
\text { - Sell logs to other wood-based } \\
\text { firms }\end{array}$ & $\begin{array}{l}\text { - Forest charges from trees cut in } \\
\text { residual forests } \\
\text { - Profit share from sale of } \\
\text { plantation products (IFMP only) } \\
\text { - Land rentals (IFMP only) }\end{array}$ \\
\hline
\end{tabular}

Both the Don Mariano Perez PO and the Sta. Maria-Magkalape Association began harvesting in the year 2000, the former in residual production forests and the latter in tree plantations developed under Loan 1, mostly Gmelina arborea trees. As a result, their members have become very willing to plant tree species in their claimed areas. According to the members, the projects have given them a reliable source of income, employment opportunities, and better social status compared to non-members of the people's organisation and other communities in the area. ANAK-Jamindan PO will be able to utilize the tree plantations developed under the project for at least eight years (for Gmelina arborea) after they were established (1997) under the comprehensive site development component of the project. 
The financial viability of the Community-Based Forest Management projects is enhanced by the agroforestry component, which provides the members with income and food sources while waiting to harvest the trees. This is very important because experience shows that project participants tend to forget the terms of their contracts when there is not enough food and money for their basic needs. The provision of a loan facility by the cooperatives is also an important consideration for members, who used to depend on informal loan sources that charge very high interest rates. As is often the case, the members' income from their harvest is barely enough to repay loans provided by unscrupulous moneylenders. Still, the continuous provision of this service depends on the members themselves. As was noted earlier, some members are very good in borrowing but not in paying.

Admittedly, the scale of timber production of the projects can be considered small. They cannot provide the volume that Integrated Forest Management Agreement holders can. Prospective buyers, who may wish to reduce their transaction costs, may shun them, striking better bargains with just one or a few big producers. To address this problem, the people's organisations can form a federation to handle the marketing of their products. The federation can facilitate the collection of the products from the people's organisations to meet the buyers' volume and species requirements.

The main reason why the three companies in the study applied for an Integrated Forest Management Agreement was to secure the raw material requirements of their owners' or sister company's wood-based enterprises. Woodland Incorporated has reopened its sawmill in anticipation of the wood it will produce from the Integrated Forest Management Program area. While it was engaged in the furniture business before, it has shifted to the production of housing components like doors and jambs. It also plans to sell excess logs to other sawmills in the area. The company does not see any problem in disposing of the wood because there are many wood-based industries in Isabela and Region 2. The owner of Iloilo Commercial is engaged in the furniture business and also plans to open a lumberyard. The matchwood produced by Casilayan Corporation also has a sure buyer, its sister company Royal Match, Inc.

The financial analysis evaluates only the tree plantation component. The benefits and costs associated with the other components (e.g., agriculture and livelihood) are not included because of the lack of information for some of the study sites. To allow comparison, all values were adjusted to the Year 2000 using the appropriate average inflation rate. The NPV in Philippine pesos (PhP) were converted to their US dollar values using a conversion rate of PhP45 for US\$1.

The financial indicators of feasibility of the three Community-Based Forest Management and Integrated Forest Management case studies are presented in Table 4.2. The bases and assumptions used in the financial analysis are given in Annex 2 while the cash flow tables are given in Annex 3 to 8 .

Despite the inclusion of the costs of community organising and comprehensive site development in the cash flow, the total financial NPV at 15\% discount rate of Don Mariano Perez PO and Sta. Maria-Magkalape Association is still positive at US \$57,105 and US $\$ 158,758$, respectively. The high revenues expected from the two people's organisations' plantations as well as the timber stand improvement component of Don Mariano Perez PO 
Table 4-2. Financial indicators of feasibility of the case studies

\begin{tabular}{|c|c|c|c|}
\hline \multirow{3}{*}{ Case study } & \multicolumn{3}{|c|}{ Financial indicators } \\
\hline & \multicolumn{2}{|c|}{ NPV (i=15\%) } & \multirow{2}{*}{$\begin{array}{l}\text { IRF } \\
\text { (\% }\end{array}$} \\
\hline & (P) & (US\$) & \\
\hline \multicolumn{4}{|c|}{ Community-Based Forest Management Program } \\
\hline $\begin{array}{l}\text { Don Mariano Perez } \mathrm{PO}^{1} \\
\text { Total } \\
\text { Per Ha }\end{array}$ & $\begin{array}{r}2,569,734 \\
829\end{array}$ & $\begin{array}{r}57,105 \\
18\end{array}$ & 29 \\
\hline $\begin{array}{l}\text { ANAK-Jamindan } \mathrm{PO}^{1} \\
\text { Total } \\
\text { Per Ha }\end{array}$ & $\begin{array}{r}(3,353,141) \\
(3,346)\end{array}$ & $\begin{array}{r}(74,514) \\
(74)\end{array}$ & 10 \\
\hline $\begin{array}{l}\text { Sta. Maria-Magkalape Association }{ }^{1} \\
\text { Total } \\
\text { Per Ha }\end{array}$ & $\begin{array}{r}7,144,094 \\
3,800\end{array}$ & $\begin{array}{r}158,758 \\
88\end{array}$ & 24 \\
\hline \multicolumn{4}{|c|}{ Integrated Forest Management Program } \\
\hline $\begin{array}{l}\text { Woodland Incorporated }{ }^{2} \\
\text { Total } \\
\text { Per Ha }\end{array}$ & $\begin{array}{r}(7,502,329) \\
(7,655)\end{array}$ & $\begin{array}{r}(166,718) \\
170\end{array}$ & 5 \\
\hline $\begin{array}{l}\text { Iloilo Commercial }^{3} \\
\text { Total } \\
\text { Per Ha }\end{array}$ & $\begin{array}{r}17,023,855 \\
34,048\end{array}$ & $\begin{array}{r}378,308 \\
757\end{array}$ & 39 \\
\hline $\begin{array}{l}\text { Casilayan Corporation }{ }^{4} \\
\text { Total } \\
\text { Per Ha }\end{array}$ & $\begin{array}{r}40,064,696 \\
8,013\end{array}$ & $\begin{array}{r}890,327 \\
178\end{array}$ & 19 \\
\hline
\end{tabular}

Notes:

${ }^{1}$ Costs and revenues were based on the Community Resource Management Framework/Annual Work Plan

${ }^{2}$ Based on the company's feasibility study

${ }^{3}$ In the absence of cost and yield estimates in the company's Indicative Development Plan, cost and revenue projections were based on the estimates of the Ecosystems Research and Development Bureau's "Development and Management of Forest Plantations" Guidebook, 1998.

${ }^{4}$ Cost and yield estimates were based on the company's Comprehensive Development and Management Plan

are able to compensate for the heavy costs incurred during the initial years. On a-per ha basis, the NPV of Sta. Maria-Magkalape is the highest at US\$ $88 /$ ha. The IRR of $29 \%$ and $24 \%$ of Don Mariano Perez PO and Sta. Maria-Magkalape Association, respectively, are also greater than the discount rate of $15 \%$. Thus, the two projects are financially feasible.

On the other hand, the NPV of ANAK-Jamindan PO is negative at (US \$74,514) or (US\$ 74) per ha and its financial IRR of $10 \%$ is less than the $15 \%$ discount rate. This could be attributed to the low projected timber harvests of the people's organisation. The yield estimates were observed to be quite conservative, which could also be because of the slower growth rate of trees in the area. Comparatively speaking, the conditions in the provinces of Quirino (Don Mariano Perez Farmers Multipurpose Cooperative) and Agusan del Sur (Sta. Maria-Magkalape Association) are more suited to timber growing than those in the province of Capiz. The NPV of ANAK-Jamindan PO tree plantation component becomes positive only if the cost of community organising is excluded, resulting in a total NPV of US $\$ 8,091$ and an IRR of $16 \%$. The project should thus re-evaluate its strategies and exert more effort to improve the yields of the plantations or the marketing of its products. Otherwise, the interest of the members in the project will not be sustained and this could cause the project to fail. 
The tree plantation component of the two of the Integrated Forest Management Program case studies is feasible from a financial point of view. Casilayan Corporation has the highest total NPV at US $\$ 890,327$, but Iloilo Commercial's per ha NPV and IRR are the highest at US\$ 757/ha and 39\%, respectively. The difference in the results of the two indicators can be attributed to Casilayan Corporation's huge development expenses during the first 11 years because of the large scale of its operations. Despite having thinning revenues from Year 4 until Year 11, the losses during this period were still heavy. On the other hand, Iloilo Commercial had losses only during the first three years. Beginning Year 4, it should have had revenues from its plantation thinning, resulting in positive net revenues in that year. Woodland Incorporated's NPV of (US\$166,718) and IRR of 5\% indicate that the timber production enterprise of the company is not feasible. This is mainly because of the high costs during the first four years of its operations.

The good financial indicators of Sta. Maria-Magkalape Association and Casilayan Softwood Development Corp. can be attributed to their good yield estimates because both are located in Agusan del Sur in the Caraga Region. As mentioned before, the biophysical characteristics of this region are generally considered to be well suited to timber growing, especially the even distribution of rainfall throughout the year. Both agreement holders also have good access to wood markets because of their proximity to Butuan City, considered the "Timber Capital" of the Philippines.

The financial NPV and IRR of ANAK-Jamindan PO indicate that the project is not feasible if the cost of the community-organising component is included. The feasibility indicators were affected by the low projected yields that were used in determining the revenues for the cash flow. The low yields can be attributed to the slow growth rates of trees because the areas are generally degraded or dominated by Saccharum spontaneum, which tends to overgrow the planted seedlings. The area is also prone to grassland fire.

The indicators of Iloilo Commercial should be taken with caution because these were computed using secondary data. There were no yield estimates for the species specifically for the province of Iloilo that take into consideration the biophysical characteristics of the site that could affect the tree plantations' growth rate.

The proportions of the costs of various activities in relation to the total costs (present values) are summarised in Table 4.3. The Casilayan Softwood Development Corp. is not included in the comparison because the cost components in its Comprehensive Development and Management Plan are expressed by the kind of inputs and not by activity.

The cost proportions of the activities of the people's organisations vary. For example, ANAKJamindan PO has attributed about $48 \%$ of its costs to community organising, but the other two organisations do not attribute as much to this budget item. This was actually controversial because when ANAK-Jamindan PO's area for comprehensive site development was reduced, only the budget for this activity was affected, while the budget for community organising was not. The members of the organisation and the forester of the Community Environment and Natural Resources Office - Sigma assigned to the project found this irregular. In effect, the assisting organisation was not adversely affected by the reduction, but it was the people's organisation that suffered the most. The members were subsequently demoralised. 
Only Don Mariano Perez PO has provided 'assisted natural regeneration' because it is the only one among the people's organisations that has residual production forests in its area. It also has the highest proportion of timber harvesting costs among the three people's organisations, even higher than the two private companies. For the two private companies, the most significant activities based on cost proportions are forest protection and maintenance, and timber harvesting. These are higher than those of the people's organisations.

Table 4-3. Proportion of costs for various activities (of the case studies)

\begin{tabular}{|c|c|c|c|c|c|}
\hline \multirow[b]{2}{*}{ Activity } & \multicolumn{5}{|c|}{ Proportion of costs (\%) } \\
\hline & $\begin{array}{c}\text { Don } \\
\text { Mariano } \\
\text { Perez PO }\end{array}$ & $\begin{array}{c}\text { Anak- } \\
\text { Jamindan } \\
\text { PO }\end{array}$ & $\begin{array}{l}\text { Sta. Maria- } \\
\text { Magkalape } \\
\text { Association }\end{array}$ & $\begin{array}{l}\text { Woodland } \\
\text { Incorporated }\end{array}$ & $\begin{array}{c}\text { Iloilo } \\
\text { Commercial }\end{array}$ \\
\hline Pre-operating expenses & & & & 0.51 & \\
\hline Community organising & 21.97 & 47.99 & 11.31 & & \\
\hline $\begin{array}{l}\text { Plantation/comprehensive site } \\
\text { development }^{6}\end{array}$ & 19.18 & 37.46 & 48.87 & 9.63 & 18.47 \\
\hline Assisted natural regeneration & 13.05 & & & & \\
\hline $\begin{array}{l}\text { Forest protection and } \\
\text { maintenance }\end{array}$ & & 1.87 & 3.86 & 44.67 & 35.98 \\
\hline Timber harvesting & 45.8 & 12.68 & 27.79 & 33.52 & 36.46 \\
\hline Training & & & 0.46 & & \\
\hline $\begin{array}{l}\text { Project management/overheads/ } \\
\text { Administrative costs }\end{array}$ & & & 7.70 & 11.67 & 9.09 \\
\hline TOTAL & 100.00 & 100.00 & 100.00 & 100.00 & 100.00 \\
\hline
\end{tabular}

Just like the other ventures, the long term sustainability of the Community-Based Forest Management and Integrated Forest Management projects depend on their efficiency, and how well they can produce and market their products. At present, it is the agreement holders themselves who look for their buyers, without much assistance from the government. One would expect that this would work out fine for the Integrated Forest Management Agreement holders, but this is not necessarily true. Casilayan Corporation admitted that they are finding it difficult to find buyers for the excess wood products that their sister company could not buy. When they do sell to other parties, the prices are usually lower than the sister company's buying price. The company can sell to a limited number of buyers because there are not many buyers of Endospermum peltatum wood.

A sensitivity analysis was conducted to evaluate the impacts of stress on the viability of the projects. For those case studies that were found feasible, the following scenarios were used:

Scenario 1: $\quad 25 \%$ increase in total costs

Scenario 2: $\quad 25 \%$ decrease in total revenues

Scenario 3: Simultaneous $10 \%$ increase in total costs and $10 \%$ decrease in total revenues 
For the case studies that were found to be infeasible, the following scenarios were used:

Scenario 1: $\quad 25 \%$ decrease in total costs

Scenario 2: $\quad 25 \%$ increase in total revenues

Scenario 3: Simultaneous $10 \%$ decrease in total costs and $10 \%$ increase in total revenues

The results of the sensitivity analysis (Table 4.4) show that the financial viability of the projects is more sensitive to the $25 \%$ decrease in total revenues (Scenario 2 ) than to the $25 \%$ increase in costs (Scenario 1). Don Mariano Perez PO, Sta. Maria-Magkalape Association, Iloilo Commercial, and Casilayan Corporation remained financially viable under the three scenarios.

ANAK-Jamindan PO and Woodland Incorporated will have to find ways of decreasing their production costs and/or increase their revenues. The latter can be done by undertaking silvicultural interventions to improve the yield, as well as actively looking for buyers who will offer higher prices.

Table 4-4. Results of the sensitivity analysis

\begin{tabular}{|c|c|c|c|}
\hline \multirow{2}{*}{ Scenario } & \multicolumn{2}{|c|}{ NPV (i=15\%) } & \multirow[t]{2}{*}{ IRR (\%) } \\
\hline & PhP & US \$ & \\
\hline \multicolumn{4}{|c|}{ Scenario $1: 25 \%$ increase in costs of plantation development, ANR and harvesting } \\
\hline 1. Don Mariano Perez PO & $1,439,880$ & 31,997 & 23 \\
\hline 2. Sta. Maria-Magkalape Association & $3,327,393$ & 73,942 & 19 \\
\hline 3. Iloilo Commercial & $13,018,331$ & 289,296 & 32 \\
\hline 4. Casilayan Corporation & $11,282,143$ & 250,714 & 16 \\
\hline \multicolumn{4}{|l|}{ Scenario 2:25\% decrease in total revenues } \\
\hline 1. Don Mariano Perez PO & 44,210 & 982 & 15 \\
\hline 2. Sta. Maria-Magkalape Association & $1,541,369$ & 34,253 & 17 \\
\hline 3. Iloilo Commercial & $8,762,367$ & 194,719 & 30 \\
\hline 4. Casilayan Corporation & $1,265,969$ & 28,133 & 15 \\
\hline \multicolumn{4}{|c|}{ Scenario 3: Simultaneous $10 \%$ increase in costs and $10 \%$ decrease in total revenues } \\
\hline 1. Don Mariano Perez PO & 806,289 & 17,918 & 20 \\
\hline 2. Sta. Maria-Magkalape Association & $3,376,323$ & 75,029 & 19 \\
\hline 3. Iloilo Commercial & $12,117,053$ & 269,268 & 32 \\
\hline 4. Casilayan Corporation & $13,032,184$ & 289,604 & 16 \\
\hline \multicolumn{4}{|l|}{ ANAK-Jamindan PO } \\
\hline 1. Decrease costs by $50 \%$ & 519,816 & 11,551 & 16 \\
\hline 2. Increase total revenues by $80 \%$ & 161,076 & 3,579 & 15 \\
\hline 3. Decrease costs by $40 \%$, increase revenues by $50 \%$ & $1,260,452$ & 28,010 & 17 \\
\hline \multicolumn{4}{|l|}{ Woodland Incorporated } \\
\hline 1. Decrease costs by $50 \%$ & 236,242 & 5,250 & 15 \\
\hline 2. Increase total revenues by $95 \%$ & 73,742 & 1,639 & 15 \\
\hline 3. Decrease costs by $35 \%$, increase revenues by $30 \%$ & 307,114 & 6,825 & 15 \\
\hline
\end{tabular}

Note: 'US \$1:PhP45 


\subsection{Market for timber products}

The common practice for the case studies, having already harvested their timber, is to look for buyers themselves. Only the people's organisations were assisted by the Department of Environment and Natural Resources, while the private company did not receive assistance (Table 4.5).

The project staff of the Community Forestry Project-Quirino assisted the Don Mariano Perez PO in identifying potential wood buyers to ensure that the latter would not be taken advantage of. The cooperative had a log supply contract with Spiritwood Corp. for the year 2000. Thus, there was already an assured market for its log output. The cooperative would sell 50 to $100 \mathrm{~m}^{3}$ of logs to Spiritwood, but the price was still being negotiated at the time of the research team's visit.

Sta. Maria-Magkalape Association had a contract with PACWOOD to sell 500 Gmelina arborea poles, a total volume of $200 \mathrm{~m}^{3}$, to the company. The prices upon delivery were specified in the contract, which varied depending on the 'small' and 'big-end' diameters and the length. The terms of payment are also specified in the contract. The contract was signed by the Chairman of the people's organisation and the Manager of PACWOOD, with the Barangay Captain, Community Environment and Natural Resources Officer, and Provincial Environment and Natural Resources Officer acting as witnesses, and the Department of Environment and Natural Resources ARED for Technical Services giving the final approval.

The involvement of the local government unit and the Department of Environment and Table 4-5. The mechanism to set and renegotiate the price and implications for tree growers

\begin{tabular}{|c|c|c|}
\hline Case Study ${ }^{1}$ & Mechanism & Implication for organisation/company \\
\hline $\begin{array}{l}\text { Don Mariano } \\
\text { Perez } \mathrm{PO}^{2}\end{array}$ & & $\begin{array}{l}\text { - Solely bears the cost of marketing } \\
\text { - Target buyers limited to those in the province/ } \\
\text { region }\end{array}$ \\
\hline $\begin{array}{l}\text { Sta. Maria- } \\
\text { Magkalape } \\
\text { Association }\end{array}$ & $\begin{array}{l}\text { - Searches for buyers } \\
\text { - Negotiates a price with buyers }\end{array}$ & $\begin{array}{l}\text { - Solely bears the cost of marketing } \\
\text { - Price in province is low due to intense } \\
\text { competition, Caraga region is the timber capital } \\
\text { of the Philippines } \\
\text { - Gmelina arborea is not a preferred species in the } \\
\text { region } \\
\text { - Has begun replacing Gmelina arborea with } \\
\text { Paraserianthes falcataria }\end{array}$ \\
\hline $\begin{array}{l}\text { Casilayan } \\
\text { Corporation }\end{array}$ & $\begin{array}{l}\text { - Sister company buys wood at a } \\
\text { good price } \\
\text { - Looks for buyers for the wood } \\
\text { that the sister company cannot } \\
\text { buy } \\
\text { - Other buyers offer lower prices }\end{array}$ & $\begin{array}{l}\text { - Solely bears the cost of marketing } \\
\text { - Product commands low price because of limited } \\
\text { use for Endospermum peltatum } \\
\text { - Plans to plant other species like Paraserianthes } \\
\text { falcataria }\end{array}$ \\
\hline
\end{tabular}

Notes:

${ }^{1}$ Only case studies that have harvested timber are included

${ }^{2}$ Don Mariano Perez Farmers Multipurpose Cooperative, Inc.

${ }^{3}$ St. Maria-Magkalape Association

${ }^{4}$ Casilayan Softwood Development Corp. 
Natural Resources in drawing up the contract ensures that the people's organisation will not be shortchanged in the deal. In Compostella Valley, Mindanao, a buyer promised private tree growers good prices if they delivered the logs to Davao. There was no formal log purchase agreement or advanced payment. When they reached Davao, the buyer was nowhere to be found, and the tree growers had to sell their logs at very low prices. The incident could have been a case of the buyer running out, but it could also have been a calculated move to drive wood prices down. The sellers deemed it wiser to sell the logs at a loss rather than take them back to their province.

The people's organisations are not required to sell to only one buyer. For example, Sta. MariaMagkalape Association is actively searching for buyers who will offer better prices for its wood (outputs). It has a lumber supply agreement with TOWA Industries in the province of Cebu to sell $20,000 \mathrm{bd} \mathrm{ft}^{6}$ of lumber at a price of PhP11/bd ft $(\$ 0.24 / \mathrm{bd} \mathrm{ft})$ delivered. The people's organisation said that the price offered by the Japanese buyer is higher compared to the prevailing price of lumber in Butuan City, which is PhP8/bd $\mathrm{ft}$. With an average transportation cost of $\mathrm{PhP} 2 / \mathrm{bd} \mathrm{ft}$, the people's organisation stands to earn $\mathrm{PhP} 1 / \mathrm{bd} \mathrm{ft}$ more, or PhP 20,000/month more than if it sells lumber in Butuan City.

It is highly possible that the people's organisations will face the same problem that private or spontaneous tree growers have in marketing their products. The common practice is to look for buyers only when the trees are ready for harvest. As such, the buyers do not have much input in plantation establishment and development, and there is no guaranteed price. An out-grower scheme can be more advantageous to the tree grower where an agreement can be made between the buyer and the people's organisation earlier, e.g. at the time of plantation establishment or even before. This way, the buyer would have a greater stake in the venture, and would be more active in helping the people's organisation to succeed.

The people's organisations should strive to go into value-adding processing activities so middlemen who buy raw materials at very low prices cannot take advantage of them. These would also provide additional income opportunities for the members who can be trained in furniture making and similar activities. There are many processing firms in Regions 2 and 13 because of the favourable wood supply situation, whereas they are not as active in Region 6. However, the agreement holders in Region 6 should consider this as an opportunity because they have less competition.

One would think that since Casilayan Softwood Development Corp.'s plantations were developed mainly to supply the matchwood requirements of its sister company, it would no longer have problems in marketing its products. However, since the company is selling mainly to Royal Match, Inc., it has been affected by Royal Match, Inc.'s performance, which has declined in recent years due to the entry of disposable lighters from China. The company could sell its excess wood to companies outside JAKA, but these companies buy wood at much lower prices compared to the price paid by Royal Match, Inc. Even though Casilayan Softwood Development Corp. is relatively bigger than the other Integrated Forest Management Projects included in this study, it is still affected by the problematic market for wood in the country.

From the national perspective, there should be a good market for wood, just by looking at the country's wood importations (about 30\% of the country's wood requirements in 1998). 
However, the case studies that have begun harvesting are finding difficulty in marketing their products, especially the two case studies in Mindanao. Both are located in the Caraga Region, where the competition in the wood market is high due to the many log producers in the area.

In the absence of organisations for agreement holders, the marketing system is inefficient because the tree growers have to bear all the marketing costs, which eats up their profits. A significant part of the price goes to transportation costs, especially the inaccessible Community-Based Forest Management case studies.

The government should link the agreement holders with the markets in Luzon and the Visayas. Doing this would mean higher foreign exchange savings due to decreased wood importation, and helping the tree growers who have not only invested money but also time.

\subsection{Information sharing}

Transparency is important in both the Community-Based Forest Management Program and Integrated Forest Management Program to gain the confidence and trust of the stakeholders in each other and minimize conflicts. Commonly, problems arise if participants believe that they have been short changed in the sharing of benefits, e.g. in apportioning job contracts amongst people's organisation or local community members.

The officers of the people's organisations are bound to make all transactions transparent, and should allow members, the Department of Environment and Natural Resources and other concerned parties access to information and documents. The members usually clarify issues and/or problems during General Assembly meetings. Transparency is further ensured through the regular monitoring and evaluation that the Department of Environment and Natural Resources, together with the local government unit, undertakes.

The buyers of the people's organisations' products negotiate the terms of sale with the people's organisation, and compete with the prices that other buyers offer. However, the quality of market information available to the people's organisations depends on the amount of effort they exert in scouting for buyers.

Woodland Incorporated and Casilayan Softwood Development Corp. have access to market information, mostly because of their own efforts. Even the indigenous peoples are aware of the prevailing log prices in Butuan City, and use these as their basis when selling the wood they harvest from their claimed areas to the company.

\subsection{Income diversity}

Table 4.6 provides a summary of the income sources of the agreement holders. Aside from the tree plantations common to all case studies, all the people's organisations have an agroforesry component. The crops planted vary, depending on the site characteristics and the members' 
needs, but banana, cassava, corn and coconut are common. Even the companies are allowed to devote a maximum of $10 \%$ of their areas to agriculture or agroforestry.

Table 4-6. Income sources of the case studies

\begin{tabular}{ll}
\hline Case study & Income sources \\
\hline Don Mariano Perez Farmers PO & $\begin{array}{l}\text { Tree plantation, agroforestry, rice farming, aquaculture, } \\
\text { livestock raising, rattan, consumer store, savings and } \\
\text { loans, mini rice mill, and mini sawmill }\end{array}$ \\
\hline ANAK-Jamindan PO & $\begin{array}{l}\text { Tree plantation, agroforestry, farm equipment rental, } \\
\text { mini rice mill, and consumer store }\end{array}$ \\
\hline Sta. Maria-Magkalape Association & $\begin{array}{l}\text { Tree plantation, agroforestry, bamboo plantation, } \\
\text { durian, and consumer store }\end{array}$ \\
\hline Woodland Incorporated & $\begin{array}{l}\text { Tree plantation, and agroforestry for recognized } \\
\text { occupants }\end{array}$ \\
\hline lloilo Commercial & Tree plantation, fruits and vegetables \\
\hline Casilayan Corporation & Tree plantation \\
\hline
\end{tabular}

As of August 2000, Don Mariano Perez PO had already established and maintained 33 ha of tree plantation and 20 ha of agroforestry. Aside from forest tree species, the people's organisation planted fruit trees, rice, banana, citrus and ginger. The members also maintain fishponds, numbering 36, which they have stocked with Tilapia nilotica.

ANAK-Jamindan PO is practicing multi-cropping both for the tree and agricultural components. Its tree crops include Gmelina arborea, Acacia mangium, and Swietenia macrophylla, while the agricultural crops include fruit trees (mango, jackfruit, citrus), banana, abaca, cassava and rice, among others. The people's organisation has also identified many prospective markets/buyers for its outputs in its marketing plan. It intends to encourage its members to undertake processing activities themselves. ANAK-Jamindan PO plans to train its members in furniture making. This value-adding activity will allow the people's organisation to save on transportation costs and sell products that command higher prices. This way, they will not be at the mercy of unscrupulous middlepersons who usually buy raw materials at very low prices and sell these at high profit margins. The people's organisation also assists farmers with the procurement of a water pump, a turtle (hand tractor), two rice threshers, and a mini-rice mill.

The tree plantations developed under Loans 1and 2 in the area of Sta. Maria-Magkalape Association consists mostly of Gmelina arborea and Acacia mangium. After harvesting, the members of the people's organisation have started to replace Gmelina arborea with Paraserianthes falcataria. They are also planting durian, abaca, banana, corn and different vegetables to provide the members with a regular source of income. As of September 2000, the Sta. MariaMagkalape Association had already acquired assets like a building to house the organisation's office, table saw, two chainsaws, karaoke, television, typewriter and battery to provide power for the appliances. It has also produced its own logging/hauling equipment. It also has plans of improving the water supply by building a reservoir. At present, the community depends completely on rainwater for its water needs. 
Sta. Maria-Magkalape Association wants to sell wood in the form of lumber, rather than logs, because of better prices. Some of the community members are already skilled in operating the table-saw because of their previous involvement with logging in the area. However, they cannot operate the table saw to its full capacity yet because the Department of Environment and Natural Resources (DENR) has not issued a permit to operate it. The DENR requires the people's organisation to conduct a 100\% inventory of the plantation area to show that the log requirements of the table-saw can be sustained. This requirement avoids the possibility of the table-saw eventually being used to process illegally cut logs.

The income sources of the Integrated Forest Management Agreement holders are less diverse than those of the people's organisations, mainly because they focus on industrial tree plantations. It is only Iloilo Commercial that has decided to allocate $10 \%$ of its total area to agricultural production because it is in the business of producing organically grown fruits and vegetables. Woodland Incorporated has an agroforestry component, but mostly as a concession to the forest occupants in its area. The Casilayan Corporation also allows the indigenous peoples living in the area to engage in agroforestry.

In general, the people's organisations have more diverse income sources that enable the communities to meet their basic needs while waiting for the trees to mature. This is more critical for the communities because unlike the companies, they do not have other business activities yet.

\subsection{Valuation of stakeholders' inputs}

The inputs of the major stakeholders in the two programs are summarised in Table 4.7. To sustain the people's organisation and community members' interests in both projects, it is important that their inputs be recognized and properly compensated, including labour and their claimed areas. This is a common source of conflict among the members of the people's organisations, or between local communities/indigenous peoples and the Integrated Forest Management Agreement holders.

A major input of the people's organisation members in the project is allowing the land they claim to be planted with trees. This input is recognized and compensated in the sharing of benefits when the trees are harvested.

The people's organisation members are generally given priority in hiring over non-members. In the case of ANAK-Jamindan PO, this was perceived to be fair. The compensation depended on the activity and was usually contracted to the members. For example, the fee for 'strip brushing ${ }^{7}$ was $\$ 15 /$ ha, $\$ 0.04 /$ seedling for planting, $\$ 44 /$ ha for fertilizer application (first year only), and $\$ 0.04 /$ spot for 'ring brushing ${ }^{8}$ ' and cultivation (done every quarter during the first year).

For Sta. Maria-Magkalape Association, the claimants used to be given priority in receiving job contracts from the people's organisation to maintain the plantations in their areas. After some time, the scheme proved to be ineffective because the claimants only performed the maintenance activities when billing time came. The people's organisation pays about $\$ 2$ / 
Day for labour for most activities except loading. The rate is the same for men and women. Women are mostly involved in nursery activities. For loading, payment is based on the volume of logs loaded. The rate is about $\$ 1.50 / \mathrm{m}^{3}$, which is shared by those involved in the loading activity.

Table 4-7. Inputs of stakeholders in the two programs

\begin{tabular}{|c|c|c|c|}
\hline \multirow[b]{2}{*}{ Program } & \multicolumn{3}{|c|}{ Stakeholder's inputs } \\
\hline & $\begin{array}{l}\text { People's Organisation/ } \\
\text { Company }\end{array}$ & DENR & Local Government Unit \\
\hline CBFMP & $\begin{array}{l}\text { - Claimed land } \\
\text { - Labour: } \\
\checkmark \text { Plantation development } \\
\checkmark \text { Involvement of women } \\
\checkmark \text { Honoraria for officers }\end{array}$ & $\begin{array}{l}\text { - Funds for community } \\
\text { organising, } \\
\text { comprehensive site } \\
\text { development } \\
\text { - Technical assistance } \\
\text { - Assistance in conflict } \\
\text { resolution }\end{array}$ & $\begin{array}{l}\text { - Infrastructure (road } \\
\text { improvement, Province of } \\
\text { Quirino) } \\
\text { - Assistance in conflict } \\
\text { resolution }\end{array}$ \\
\hline IFMP & $\begin{array}{l}\text { - Funds for plantation } \\
\text { development, forest } \\
\text { protection } \\
\text { - Road improvement and } \\
\text { maintenance } \\
\text { - Support for school teachers } \\
\text { (Casilayan Corporation) }\end{array}$ & $\begin{array}{l}\text { - Monitoring and } \\
\text { evaluation of company's } \\
\text { performance }\end{array}$ & $\begin{array}{l}\text { Social services for } \\
\text { communities }\end{array}$ \\
\hline
\end{tabular}

The officers of the people's organisations also receive honoraria for their services, especially in terms of internal policy formulation, decision-making, and implementation of project activities. There are no standard rates for all people's organisations. The honorarium paid depends on the organisations' capacity to pay.

The inputs of the Department of Environment and Natural Resources are in the form of financial and technical assistance in the community organising and comprehensive site development components of the projects. Various government agencies also provide health, educational, infrastructural and technical services. Since all the areas are inaccessible, the improvement of the road system is critical to the success of the projects. Otherwise, the members' earnings will just be eaten up by high transportation costs. The local government units' role in this aspect is important. Don Mariano Perez PO and Sta. Maria-Magkalape Association have been able to enlist the support of their respective local government units for this purpose. However, the respondent-members of ANAK-Jamindan PO complained that the allocation for road improvement was diverted to other projects. This is unfortunate because the people's organisation does not have the financial capacity to pay for this.

Woodland Incorporated and Iloilo Commercial seem to have taken more risks in getting Integrated Forest Management Agreements than Casilayan Softwood Development Corp. According to the Provincial Environment and Natural Resources Officer of Isabela, most of the other Integrated Forest Management projects in the province have not performed well. Some were not able to comply with the requirements, while others have been suspended because of violations. Despite the odds, Woodland Incorporated decided to proceed, and if it succeeds, can be a major legal supplier of logs in the province. For Iloilo Commercial, there had been no successful Integrated Forest Management project in Region 6 when it applied. 
As of March 2000, there were only four (4) Integrated Forest Management projects in the region, two of which were in the province of Iloilo.

Whenever possible, the companies hire people from the local communities/indigenous peoples living within or adjacent to the leased area. Some of the community members hired by Woodland Incorporated are satisfied with their wages because they are earning more now than before. Others are not satisfied with the compensation they get because some consider the wage rate too low and insufficient for their needs, while others would like to have security of job tenure.

The Community Environment and Natural Resources Officer of Talacogon, Agusan del Sur, confirmed Casilayan Corporation's claim that the company pays more than the agricultural and industrial wage rates. The compensation it gives to its contractors is likewise higher than the competition. As a result, there are more people who want to be contractors than the company can accommodate. As mentioned earlier, Casilayan Coporation involves the community members/indigenous peoples in its forest protection activities. It recognizes the jurisdiction of sectoral datus over their ancestral lands.

The Integrated Forest Management Agreement holders also provide services for the local government units and local communities, e.g. road improvement, transportation services and construction materials. These are reflected in the reports that they regularly submit to the Department of Environment and Natural Resources.

\subsection{Reinvestment mechanism}

For both programs, the contract period of 25 years, renewable for another 25 years, provides an incentive to replant trees. However, the contract period can still be considered too short for the tree growers to plant high-value indigenous species which take more than 30 years to mature. Thus, it is highly noticeable that the tree growers prefer fast-growing species that will allow them to have several rotations during the maximum 50-year period.

The reinvestment mechanism is explicitly stated in the Community-Based Forest Management Agreement, but not in the Integrated Forest Management Agreement. The people's organisation is required to remit $25 \%$ of its gross revenues to the government, with $12.5 \%$ going to the National Treasury and $12.5 \%$ going to the Community-Based Forest Management Fund. The fund is co-managed by the Department of Environment and Natural Resources and the people's organisation. The people's organisation will have access to this fund by submitting proposals for livelihood projects to the Department of Environment and Natural Resources. The remaining $75 \%$ of the gross revenue will go to the people's organisation. The net revenue is obtained by subtracting the relevant expenses from the gross revenue.

The people's organisation is also required to establish and manage a Community Forestry Development Fund to finance its activities like forest protection, reforestation, agroforestry, livelihood enterprises, plan preparation, purchase of tools and equipment, and other activities that will benefit the community as a whole. The Community Forestry Development Fund will come from the people's organisation's share of the sale of forest products from natural 
forests (if allowed) and plantations, endowments or grants, income from livelihood projects, and membership fees.

The people's organisations are given the freedom to decide how they will use their net incomes, for as long as the process is participatory and transparent. Table 4.8 shows the reinvestment mechanisms of the different case studies.

The self-help projects of the Don Mariano Perez PO like the consumer store and savings and loan program are well patronized by the members. The cooperative was able to buy a circular saw, two-mini rice mills, and construct a sawmill building and two stock houses using the income it had generated. According to the manager, they have accumulated enough funds so that they can pursue their activities even without financial support from other agencies. Aside from the $\$ 26,667$ accumulated capital, the organisation also has cash-on-hand of $\$ 11,111$. However, the organisation believes that it still needs technical assistance from the Department of Environment and Natural Resources.

One of the livelihood activities of ANAK-Jamindan PO is the rental of farm equipment. The fees collected that are net of labour and other expenses go to the people's organisation's funds. Even though members are given priority, non-people's organisation members can also rent the turtle and threshers. However, the research team found that the rental rates seemed to have been arbitrarily set without considering factors like investment recovery and depreciation. If rental fees are not properly set, the people's organisation will not be able to sustain its livelihood activities.

Sta. Maria-Magkalape Association is financing its activities from the $15 \%$ retention fee, under the Loan 2 project, amounting to $\$ 22,035$. The retention fee was automatically deducted from its budget for comprehensive site development to be released only after a favourable evaluation of its performance. This means that the people's organisation should have complied with all the requirements of its contract.

Sta. Maria-Magkalape Association has also provided for re-investment activities in its Annual Work Plan for plantation establishment (tree, bamboo, and durian) and maintenance, as well as support for its consumer store. It also has a credit service for its members that can be used for livelihood opportunities. For example, members who are interested in growing Musa textiles can "borrow" planting materials (suckers) from the organisation. They are to "repay" these also with suckers that can then be used by other members.

There is no specific provision in the Integrated Forest Management Agreement contract regarding the reinvestment mechanism. This is because the companies are financially independent from the Department of Environment and Natural Resources. However, it is safe to assume that the private companies will reinvest part of their earnings to further develop their areas, given the 25-year contract period and their financial investments to acquire the agreement and make the area productive. 
Table 4-8. Reinvestment mechanisms of the case studies

\begin{tabular}{|c|c|c|}
\hline Case Study & Reinvestment mechanism or activity & Remarks \\
\hline $\begin{array}{l}\text { Community } \\
\text { Based Forest } \\
\text { Management } \\
\text { Program }\end{array}$ & $\begin{array}{l}\text { - } 25 \% \text { of gross revenues go to the } \\
\text { government } \\
\checkmark 12.5 \% \text { to National Treasury } \\
\checkmark 12.5 \% \text { to CBFMP Fund }\end{array}$ & $\begin{array}{l}\text { - CBFMP Fund can be accessed by } \\
\text { the people's organisation to finance } \\
\text { livelihood projects }\end{array}$ \\
\hline $\begin{array}{l}\text { Don Mariano } \\
\text { Perez PO }\end{array}$ & $\begin{array}{l}\text { - Has a mini sawmill, } 2 \text { mini rice mills, } \\
\text { consumer store, savings and loan } \\
\text { system }\end{array}$ & $\begin{array}{l}\text { - Expects substantial revenues from timber } \\
\text { extraction } \\
\text { - Has accumulated enough funds to pursue } \\
\text { activities without financial support from } \\
\text { DENR }\end{array}$ \\
\hline $\begin{array}{l}\text { Anak-Jamindan } \\
\text { PO }\end{array}$ & $\begin{array}{l}\text { - Has mini rice mill, consumer store, } \\
\text { farm equipment rental }\end{array}$ & $\begin{array}{l}\text { - Has not harvested tree plantations yet } \\
\text { - Equipment rental rates set too low }\end{array}$ \\
\hline $\begin{array}{l}\text { Sta. Maria- } \\
\text { Magkalape } \\
\text { Association }\end{array}$ & $\begin{array}{l}\text { - Reinvestment for plantation } \\
\text { establishment (tree, bamboo, durian) } \\
\text { - Maintains consumer store, provides } \\
\text { credit services }\end{array}$ & $\begin{array}{l}\text { DENR no longer provides funds other } \\
\text { than } 15 \% \text { retention fee that the } \\
\text { organisation uses to finance its activities }\end{array}$ \\
\hline $\begin{array}{l}\text { Integrated Forest } \\
\text { Management } \\
\text { Program }\end{array}$ & $\begin{array}{l}\text { - No specific provisions for } \\
\text { reinvestment }\end{array}$ & $\begin{array}{l}\text { Bound by contract to replant or conduct } \\
\text { assisted natural regeneration in areas } \\
\text { harvested }\end{array}$ \\
\hline
\end{tabular}

\subsection{Consideration of socio-cultural conditions and needs of tree growers}

The rights of local communities and indigenous peoples/indigenous cultural communities are recognized in both programs. Claimants of areas covered by the Community-Based Forest Management Agreement are entitled to a share of the proceeds from the sale of timber. The claims of indigenous peoples/indigenous cultural communities to their ancestral lands/ domains are also respected. In fact, certified ancestral lands and domains may not be placed under any of the agreements unless the indigenous peoples or cultural communities concerned give their consent.

To avoid problems in their activities, the companies should have the acceptance and support of the local communities or indigenous peoples in their area. Some Integrated Forest Management Agreement holders, especially those in Mindanao, cover very large areas that, in many cases, have ancestral land/domain claims. The companies have to show their good intentions to get the trust of the local communities/indigenous peoples, and should be able to show how the Integrated Forest Management Agreements will benefit the latter.

Woodland Incorporated was able to secure local community support after it agreed that the forest occupants could continue to live in the area, provided they are documented and do not undertake any activity without the knowledge of the company. For the case of Iloilo Commercial, some community members were not willing to compromise with the company during the initial consultations, and this resulted in the segregation of the claimed areas.

The Department of Environment and Natural Resources confirmed that Casilayan Softwood Development Corp. has a harmonious relationship with the local government unit and local communities because the company gives high priority to its community-relations activities. 
Based on its Annual Concession Reports from 1996 to 1999, the company has spent substantial amounts in support of the local government unit and to enhance the welfare of the communities in the area.

\subsection{Conflict resolution mechanism}

Conflicts can arise from within the agreement holders' structure or in their relationship with the Department of Environment and Natural Resources, local government unit, NGO, and other parties. Table 4.9 summarises the approaches used by the key stakeholders in resolving conflicts. For the Community-Based Forest Management Program, the people's organisation develops its own mechanism to resolve internal conflicts. This should be consistent with the beliefs and traditions of the people's organisation and may thus vary from one organisation to another. A common venue for resolving conflicts among the members is the General Assembly meeting held every month. The most common cause of conflict among people's organisations is the sharing of benefits. Two of the people's organisations included in this study lost some members for this reason.

Table 4-9. Approaches used by stakeholders to address conflicts or issues

\begin{tabular}{|c|c|c|c|}
\hline Approach & Problems Addressed & Lead Facilitators & Adopted by \\
\hline General assembly & - Benefit sharing & $\begin{array}{l}\text { Board of directors/ } \\
\text { officers of people's } \\
\text { organisations }\end{array}$ & $\begin{array}{l}\text { Don Mariano Perez PO, } \\
\text { Anak-Jamindan PO, } \\
\text { Sta. Maria-Magkalape } \\
\text { Association }\end{array}$ \\
\hline $\begin{array}{l}\text { Public hearing/ } \\
\text { consultation meeting }\end{array}$ & $\begin{array}{l}\text { - Benefit sharing between } \\
\text { community and company } \\
\text { - Continued presence of } \\
\text { community in the area } \\
\text { - Land claims }\end{array}$ & $\begin{array}{l}\text { DENR, LGU, } \\
\text { community leaders }\end{array}$ & $\begin{array}{l}\text { Woodland Incorporated, } \\
\text { Iloilo Commercial, } \\
\text { Casilayan Corporation }\end{array}$ \\
\hline Dialogues & $\begin{array}{l}\text { - Problems with individual } \\
\text { members } \\
\text { - Work attitude of community } \\
\text { members hired as labourers }\end{array}$ & $\begin{array}{l}\text { Board of directors/ } \\
\text { officers of people's } \\
\text { organisations } \\
\text { DENR } \\
\text { LGU }\end{array}$ & $\begin{array}{l}\text { Don Mariano Perez PO, } \\
\text { Anak-Jamindan PO, } \\
\text { Sta. Maria-Magkalape } \\
\text { Association, Casilayan } \\
\text { Corporation }\end{array}$ \\
\hline
\end{tabular}

On the other hand, conflicts between the Integrated Forest Management Agreement holders and other stakeholders are usually resolved during consultation meetings. The agreement holders can also encounter problems with the communities living within or adjacent to their areas. The fear of being ejectedfrom the lands they occupyusually makes local communities oppose the presence of Integrated Forest Management projects. Since their relationship can affect the efficient implementation of their activities, it is important that they address these problems early on. Ignoring such conflicts can result in the burning of plantations or equipment, and in some cases can even endanger lives.

Woodland Incorporated admitted that they still have problems with some families in the area, despite their offer to buy the rights claimed by nine (9) families. Some lessees or landowners find it more practical to just pay claimants so they will move out of the area. To them, the one-shot payment is better than having to be at the continual mercy of the claimants. The 
terms of some claimants are acceptable, but others make it almost impossible for an amicable settlement to be arrived at.

For Iloilo Commercial, the local government unit and the Department of Environment and Natural Resources have been largely instrumental in resolving the conflicts between the company and community members. Several meetings were conducted to settle the community's land claim, which eventually led the Department of Environment and Natural Resources to segregate the 153 ha area.

The main source of conflict during the early years of Casilayan Softwood Development Corp. was the indigenous peoples' claim that portions of the Integrated Forest Management Project area was part of their ancestral domain. Through dialogues between the company and the indigenous peoples, with the participation of the Department of Environment and Natural Resources and the local government unit, the conflict has since been settled. The indigenous peoples have come to appreciate the benefits they get from the scheme, especially in terms of employment and community services.

The Integrated Forest Management Agreement holders can also have conflicts with their employees. The policies governing both programs emphasize the need to protect workers' rights, which should include the right to due process. In both cases, representatives from the Department of Environment and Natural Resources and the local government unit serve as facilitators or mediators. How fast a conflict is resolved depends on the nature of the conflict and the willingness of the stakeholders to compromise.

Another source of conflict for the Casilayan Softwood Development Corp. was when the company could no longer employ some members of the indigenous peoples because of their age. A compromise was arrived at and they were hired as honorary sectoral guards or datus whose responsibility it was to protect the planted area, personnel and equipment. In general, the datus have been successful in protecting their sectoral areas.

Only the community and indigenous peoples in Iloilo Commercial and Casilayan Corporation have organisations, i.e., the AGBADPRO Upland Farmers Association and the Manobo Banwaon Talaandig Federation, respectively. These organisations have been active in negotiating with the companies on behalf of their members. The chairman of the Manobo Banwaon Talaandig Federation acts as the spokesperson of the indigenous peoples and deals with the Department of Environment and Natural Resources, local government unit and the private sector like Casilayan Softwood Development Corp. In 2000, the company requested the chairman of the federation to organise the indigenous peoples into a cooperative to be registered with the Cooperative Development Authority so that the company could enter into contracts with the indigenous peoples. The company wants its transactions with the latter to be covered by a formal contract to ensure that the contracting parties act responsibly. The company respects the rights of the indigenous peoples, but it also expects them to be conscious of their responsibilities in their relationship with the company. 


\subsection{Renegotiation mechanism}

Within the people's organisations, the members can negotiate over matters like benefit sharing and other privileges during the General Assembly meetings. For example, the members of Sta. Maria-Magkalape Association finally agreed on the benefit-sharing mechanism after six monthly meetings, and only after the Department of Environment and Natural Resources Site Coordinator and Focal Person presented to the body the pros and cons of various schemes.

The companies can renegotiate the terms of their agreement with the Department of Environment and Natural Resources under meritorious circumstances, as in the case of Iloilo Commercial and the Casilayan Corporation. As mentioned before, CasilayanCorporation had an Industrial Tree Plantation (started in 1983) but this was converted to an Industrial Forest Management Agreement in 1992. The company appealed to the Department of Environment and Natural Resources for its 25-year Comprehensive Industrial Tree Plantation Management and Development Plan to remain in force until 2008. During the time when the agreement was converted to an Integrated Forest Management Agreement, the company has already developed 4,096.72 ha of the leased area into plantations and has adhered to the requirements of the lease agreement. After evaluating the merits of the appeal, the Department of Environment and Natural Resources allowed the company to continue using its existing plan.

The Department of Environment and Natural Resources also allows the companies to appeal decisions suspending or cancelling the Integrated Forest Management Agreement within 30 days upon receipt of the decision. Meetings with local communities and local government units to resolve issues and problems are held as necessary. 


\section{Conclusions and recommendations}

The processes involved in both programs (Community Based Forest Management Program and Industrial Forest Management Program) were structured following the standard formats prescribed by, and with the full participation of, the Department of Environment and Natural Resources. However, each agreement has unique provisions that have been crafted with partners in mind, particularly with respect to allowable activities, exemption from forest and administrative charges, and transferability of the agreement.

Both schemes provide for the interests of the participants. For the CBFMP, the people's organisations are encouraged to grow agroforestry crops and engage in other livelihood activities to provide an alternative source of income, while waiting for the trees to mature. The provision of early benefits is very critical. This is important to keep the people from reverting back to slash-and-burn cultivation. On the other hand, the IFMP is focussed on the commercial production of plantation timber. Except for one, all the case studies have diverse income sources. The company that does not have diverse income sources has experienced the economic and ecological disadvantages of monoculture plantations, and has begun planting other species in the areas that have been harvested.

Based on the financial analysis, the tree plantation components of the case studies, except for one, are all feasible. However, the favourable indicators derived are hinged largely on the assumption that they will be able to sell their products at good prices. At present, tree growers in Mindanao are experiencing problems in marketing their products because of a localised surplus. This is ironic because the wood processing firms in the rest of the country are importing large quantities of logs. This issue has been raised in various forums, but no decisive action has yet been taken. If the government fails to act, all its efforts to encourage the communities, private sector and even private individuals to develop tree plantations will just go to waste.

The inputs of the Department of Environment and Natural Resource partners into both programs are well recognised through the incentives provided in their respective policies. In terms of the benefit sharing mechanism, for the CFBMP, it is stated in the policy that the government and the people's organisation's shares should be based on gross sales. When this was implemented in one of the case studies, the organisation was forced to stop its operations because it could not afford to pay the government's share. The provision is already being reviewed, but the inclination is to base the share on the 'farm gate' price of the logs, which is still inclusive of harvesting costs.

On the other hand, the results of the study show that the Integrated Forest Management Agreement holders not only share benefits with the government, but also with local government units and communities. This is true even for those companies that have not begun their harvesting operations. This sharing of benefits is important to gain the support of the other stakeholders. It also shows that the private sector is not only the government's partners in reforesting degraded lands, but also in delivering basic services to the people in the uplands. 


\subsection{Problems and relevant recommendations for both programs}

Specific problems observed from the field need to be addressed together with the stakeholders concerned. Some of the problems identified, and the corresponding recommendations for better implementation and direction for future initiatives of CBFMP and IFMP, are as follows:

Linking to the market. The Department of Environment and Natural Resources and the Department of Trade and Industry, should be more aggressive in linking the buyers with the tree growers in general, for both local and export markets. As yet, there seems to be no serious effort to help people's organisations in this aspect, and they usually have to look for and negotiate with the buyers themselves.

To improve the marketability of the people's organisations' products, it may be worthwhile labelling them as having been produced by local communities, indigenous cultural communities or indigenous peoples because there are consumers who would like to patronise the products produced by these previously disadvantaged members of society. The government can also even provide incentives for firms that buy the products of Community-Based Forest Management projects in terms of lower taxes and assured raw material sources.

Even though the private companies that hold the Integrated Forest Management Agreements have more resources than people's organisations, they still find difficulty in marketing their products. It is ironic that for one company, its sister company provides better prices than other wood buyers because of localized wood surplus, owing to the many wood producers in the region. On a national scale, however, the Philippines is a net importer of primary wood products. The country does not only import logs, lumber, veneer, plywood and other wood panels, but even crates, pallets and toothpicks when many tree growers in Mindanao cannot even sell all their products, let alone sell at a good price.

Careful selection of species to plant. Program participants should choose the tree species to plant based on a careful evaluation of the market and site-species compatibility. The bandwagon phenomenon has manifested itself in many of the case studies, with the end result of poor product marketability and, in some cases, low yield. Fast-growing species used to be heavily favoured in government reforestation and forest development projects. At present, the government is encouraging the use of indigenous species that, while slower growing, can command higher prices at maturity than their faster-growing counterparts. Likewise, indigenous tree species are more resistant to pests and diseases compared to exotic species. However, the longer rotation required by these species makes them less attractive to tree growers, especially the upland farmers who have higher time preferences. Allowing the tree growers to engage in agroforestry, helps address this issue.

Adoption of an outgrower scheme for both programs. At present, most of the risks in timber growing fall on the tree growers. An outgrower type of arrangement that involves both buyers and sellers early on would spread the risk, and program participants would have assured markets for their products. This would also be effective in linking the tree growers with their buyers. 
Value added. As much as possible, the people's organisations should undertake value-adding activities to generate higher incomes. Instead of selling logs, for example, they should process the wood into lumber or even furniture. In this respect, the government could again play an important role in providing the people's organisations access to training programmes for the processing of wood and other forest products. The federation could also work for the establishment of processing facilities that could service its members who may not have enough funds to establish their own. These processing facilities should be strategically located to minimise transportation costs.

The Community-Based Forest Management projects should work for forest certification so they can have access to world markets and not be limited to local buyers. However, government assistance will be required because forest certification can be expensive for communities. It will improve the people's organisations' position if they can form an association to strengthen the members' technical and business capabilities, and actively search for markets.

None of the Integrated Forest Management projects included in the study is undergoing forest certification. The same is true for many other Integrated Forest Management projects in the country. This is one aspect that the Department of Environment and Natural Resources should pursue vigorously if the country is to remain active in the world market for forest products. Forest certification can be used to the Integrated Forest Management Agreement holders' advantage because most of their wood outputs come from plantations and not from natural forests. However, the cost of forest certification is quite prohibitive for most Integrated Forest Management Agreement holders.

The agreement holders should also explore the possibility of entering the market for carbon. Towards this end, studies should be conducted on the amount of carbon that different kinds of plantations can sequester.

Open communication lines among stakeholders, and a recognized and respected system of resolving conflicts. Transparency in all transactions is important to minimise conflicts, whether within the people's organisations or companies, or as they relate to other stakeholders.

In all case studies, the participation of the Department of Environment and Natural Resources and the local government units is important in resolving conflicts. The people's organisations have their own systems of resolving conflicts over land rights, which are generally respected by their members. The most common approaches used are the general assembly and dialogues for people's organisations, and public hearings or consultation meetings with the companies. However, the respondents from the people's organisations admitted that they do not really impose sanctions on members who choose not to heed the officers, making the mechanism useless in such cases. Thus, the people's organisations should draw up ways of making erring members adhere to the regulations.

Private companies involved in the Integrated Forest Management Program encounter bigger problems in dealing with land claimants. They usually address these problems by providing benefits to the claimants, such as employment, allowing them to continue planting agricultural/agroforestry crops, advancing agricultural inputs, constructing and maintaining roads, and even supporting or providing medical and educational services. The Department of Environment and Natural Resources and the local government units should see to it that 
not too many demands are made on the companies so as to affect the profitability of their operations. In the case of the communities in the Integrated Forest Management Agreement areas, those with organisations acted as one, and had more leverage in dealing with the companies than the unorganised communities. One company prefers to deal with this kind of organisation because the members act more responsibly.

\subsection{Community-Based Forest Management Program}

The success of the Community-Based Forest Management Program lies in the hands of all the stakeholders, but particularly in the people's organisations. The program will succeed only if the people's organisations are empowered, which means that they recognize that their responsibilities are equally important as, if not more important than, their rights and privileges. Government agencies, particularly the Department of Environment and Natural Resources, can only give so much assistance and support, but how these will be used by the people's organisation will spell the difference between success and failure of the CommunityBased Forest Management Program.

Early and continuous provision of benefits. Providing early and continuous benefits is more critical for the people's organisations than the companies. Failure to do so can result in members leaving the people's organisation, or even the organisation itself leaving the program. While the Community-Based Forest Management Program provides for this through agroforestry and livelihood activities, the areas usually have low productivity because of site conditions. Most of the areas are also inaccessible, and the potential profits of the people are usually eaten up by high transportation costs and heavy post-harvest losses. The government needs to address this problem.

Facilitate the access of people's organisations to the Community-Based Forest Management Fund. The reinvestment mechanism is important for the sustainability of the projects. The government is focusing more closely on how the people's organisations reinvest part of their earnings so that eventually, they will become financially independent. At the very least, the Department of Environment and Natural Resources ensures that some of the organisations' earnings will be reinvested through the Community-Based Forest Management Fund. However, there have been complaints from some organisations that it takes several months before they can draw releases from the fund for their livelihood activities. Thus, the Department of Environment and Natural Resources should find ways to facilitate fund releases.

Realistic and equitable sharing of benefits. The benefit sharing mechanism of the Community-Based Forest Management Program should be reviewed. Basing the share of the government on gross sales is unfair to the people's organisation because it is tantamount to giving the government a share of the transportation and processing costs. This provision is counter to the government's desire to make people's organisation undertake value-adding processes for efficient resource use and higher profits. The government's share should be based on the value of the standing tree, or the stumpage value. All other incremental benefits gained by the people's organisations in subsequent processing activities should be enjoyed only by the people's organisation. It would be a shame if the government loses the gains it has worked hard for in organising communities if the latter lose their trust because the benefits promised 
are not delivered. Community organising was a very expensive undertaking, financed by borrowed money, and if the Community-Based Forest Management Program fails, society will be a loser twice over.

Accessibility. Perhaps the most important problem for the Community-Based Forest Management projects in this study is the inaccessibility of the areas. All three areas are not accessible by the regular means of transport, and the bad road conditions translate to very high transportation costs. This is where the government, particularly the local government and the Department of Public Work and Highways, can come in. Improving the farm to market roads will enable the people's organisations to generate higher profits not only for their wood products but also for their agricultural crops. Since there are no post-harvest facilities in the area yet, having an efficient means of transportation will reduce post-harvest losses.

Reinvestment mechanism. The people's organisation should ensure that part of its earnings is reinvested not only in its livelihood activities but also in tree plantations. After all, the program is still forest management, although it is community-based. The tree component of the project, while long maturing, provides ecological benefits that spill over to other members of society.

Active participation of various stakeholders. The Department of Environment and Natural Resources alone cannot make the program succeed. Its role is pivotal in program implementation, as well as in providing technical and financial assistance especially to people's organisations. However, the role of the local government units in conflict resolution and in providing logistical support is also important.

The people's organisations should also form a federation (provincial or regional, depending on their number) to strengthen their bargaining positions when they deal with other parties like the Department of Environment and Natural Resources, local government units, and their buyers.

\subsection{Industrial Forest Management Program}

The challenge for the government is how to make the business environment conducive to the Integrated Forest Management Program. In the same manner that the government gives prime importance to the welfare of the indigenous cultural communities, indigenous peoples and local communities, so it should give the same protection to the Integrated Forest Management Agreement holders.

Anticipating the transaction costs. There have been cases where the operations of these companies have been hindered because they could not meet the demands of other sectors. Some of these demands are legitimate, but others are not. In some instances, other groups for reasons ranging from economic to ecological, and even political, manipulate these sectors.

To minimize this problem, all transactions between the Integrated Forest Management Agreement holder and the local communities, local government units, Department of 
Environment and Natural Resources and other relevant sectors should be documented, possibly with contracts, and the parties involved should be responsible for fulfilling their responsibilities. For the private sector to truly invest in tree plantations, it should be able to calculate its risks and not be subjected to frequent changes of perceptions, positions and decisions. There should be equitable sharing not only of benefits but also of costs among stakeholders. This will make them appreciate their stakes in the scheme and act responsibly to ensure its success.

Consistent forest plantation policies. Dynamic changes of the related forestry sector policies in the country have discouraged the private sector from investing in forest plantations. This will also affect the continuity of the partnership arrangement between the IFMA holder and other key stakeholders.

Enhance IFMA holders' investments in forest plantations. There are some IFMA holders that still operate like Timber License Agreement holders. These companies do not seriously intend to make any investment in timber plantations they are only interested in the windfall profits from the harvesting of the remaining trees available in the production forests.

Appropriate silvicultural techniques for degraded forestlands. IFMA holders are no longer operating in productive old growth forests, but mostly in degraded forestlands. As such, there are technical problems that can make investment unprofitable, eventually affecting the viability of the partnership arrangements. Thus, the species and land uses suited to these areas should be carefully studied. 


\section{References}

Department of Environment and Natural Resources Administrative Order 91-24. Shift in Logging from the Old-Growth (Virgin) Forests to Second-Growth (Residual) Forests.

Department of Environment and Natural Resources Administrative Order 93-60. 1993. Revised Industrialized Forest Management Regulations.

Department of Environment and Natural Resources Administrative Order 97-12. Guidelines for the Formulation of Community Resource Management Framework and Annual Work Plan for Community-Based Forest Management Areas.

Department of Environment and Natural Resources Administrative Order No. 96-24. Rules and Regulations Governing the Socialised Industrial Forest Management Program.

Department of Environment and Natural Resources Administrative Order No. 96-29. Community-Based Forest Management Program.

Department of Environment and Natural Resources Administrative Order No. 96-37. Revising DENR Administrative Order No. 21, Series of 1992, to Further Strengthen the Implementation of the Environmental Impact Statement (EIS) System.

Department of Environment and Natural Resources Administrative Order No. 97-04. Rules and Regulations Governing the Industrial Forest Management Program.

Department of Environment and Natural Resources Administrative Order No. 98-43. Exemption of Community-Based Forest Management Projects from the Payment of Administrative Fees.

Department of Environment and Natural Resources Administrative Order No. 98-92. Production Sharing Agreement with People's Organisation in the Harvest of Forest Plantations Owned by the Government Inside CBFMP Areas.

Department of Environment and Natural Resources Administrative Order No.99-29. Amendment of DENR A.O. No. 96-29 which Prescribes the Rules and Regulations for the Implementation of Executive Order No. 263, otherwise known as the CommunityBased Forest Management Strategy (CBFMS).

Department of Environment and Natural Resources Administrative Order No. 99-35. Revised Guidelines in the Implementation of the Resource Use Permit in CommunityBased Forest Management Program.

Department of Environment and Natural Resources Administrative Order No. 99-53. Regulations Governing the Integrated Forest Management Program (IFMP).

Department of Environment and Natural Resources Administrative Order No. 200029. Guidelines Regulating the Harvesting and Utilization of Forest Products within Community-Based Forest Management Areas.

Department of Environment and Natural Resources Memorandum Circular 97-11. 1997. Operationalization of the CBFM Program at the Regional, PENR and CENR offices. 
Department ofEnvironment and Natural Resources Memorandum Circular 98-08. Guidelines on Contracting Inside Community-Based Forest Management (CBFM) Areas.

Department of Environment and Natural Resources. 1990. Master Plan for Forestry Development.

Department of Environment and Natural Resources. 1999. Assessment of the CommunityBased Forest Management Strategy and Program.

Executive Order No. 263. 1995. Adopting Community-Based Forest Management as the National Strategy to Ensure the Sustainable Development of the Country's Forestlands Resources and Providing Mechanisms for Its Implementation.

Forest Management Bureau. 1998. Philippine Forestry Statistics. Department of Environment and Natural Resources.

Mayers, J. 2000 Company-community forestry partnerships: a growing phenomenon. Unasylva 200 51: 33-41.

Nawir, A. A. L. Santoso, and I. Mudhofar. 2003. Towards Mutually-Beneficial CompanyCompany Partnerships in Timber Plantation: Lessons learnt from Indonesia. CIFOR Working Paper No. 26. Bogor, Indonesia.

Pekin, F. 1994. Practical Cost Benefit Analysis, Melbourne, Macmillan Education, Australia.

Presidential Decree No. 705. 1975. Revised Presidential Decree No. 389, otherwise known as the Forestry Reform Code of the Philippines. As amended by PD 865, 1775, 1559, EO Nos. 273 and 277 Series of 1987, RA No. 7161.

Race, D. 1999. Forest COmpany-Community Partnership Ingredients for Success. Discussion Paper 9 April 1999. Canberra. Department of Forestry, Australia National University. 


\section{Annexes}

\section{Annex 1.The assessment guidelines (Nawir et al. 2003)}

\section{Management aspects}

The first principle is based mainly on the underlying assumption that mutually beneficial partnerships could be ensured if there is fair co-operation between key stakeholders. In partnership schemes, where a contractual agreement is essential, ideally the agreement should be designed through a participatory process involving key stakeholders. This principle is in accord with the principle of mutual acceptance by both parties of each other's aims in the agreement, as discussed by Desmond and Race (2000: 33) in their global analysis of partnership schemes. The second principle highlights the need for the technical requirements of establishing plantations under partnership schemes to be consistent with good practice and codes of conduct that correspond with the overall concept of SFPM. This principle should be clearly stated in the management plan.

Principle 1: Fair cooperation is the approach used in the management of the partnership in partnership schemes

\begin{tabular}{ll}
\hline Criteria & Indicators \\
\hline $\begin{array}{l}\text { 1. A clear agreement among key stakeholders is } \\
\text { developed through a participatory process }\end{array}$ & 1.a. Participatory socialization process \\
\cline { 2 - 2 } &
\end{tabular}

1.b. Clearly understanding and implementing the duties in balance with their rights as stated in the agreement document

2. A clear management plan is designed through a participatory process among key stakeholders 2.a. Management plan is well understood by key stakeholders

2.b. Management plan is being effectively implemented by ensuring the dissemination of information on technical and financial aspects

Principle 2: The implementation of partnership schemes encourages responsible practices of sustainable plantation forestry management

Criteria Indicators

1. Rules and guidelines of good practice in establishing plantation forestry are being adhered to in the partnership

1.a. The relevant rules and guidelines are taken into account within the management plan

1.b. The management plan is implemented following the codes of practice 


\section{Economic aspects}

The first principle is based mainly on the commercial focus of establishing plantation forestry in partnership schemes. This is important since the underlying reason for the participation of tree-growers in the partnership is to earn additional income, and they are aware that it will be a long time before receiving any returns from investing in the tree plantation. There would be no reason for developing plantations under partnership schemes that were not commercially viable, both from the tree-growers' and the company partners' points of view. The second principle relies mainly on the assumption that mutually beneficial partnerships, and their economic viability, would depend on a fair benefit-sharing mechanism and the implementation of what has been agreed by both parties. This principle also accepts the underlying assumption that benefit sharing can be based on the proportional inputs of key stakeholders and that there is a mechanism for a fair evaluation of inputs by different stakeholders and they are well recorded. In addition to key stakeholders of the company and tree-growers, fair evaluation should apply to others who are not directly involved in the partnership, such as the local government. Although, the government's contribution may be small, it could be significant and should be compensated fairly. The contribution may involve the government's role as facilitator in the socialisation process or as mediator in resolving conflicts.

\begin{tabular}{|c|c|}
\hline \multicolumn{2}{|c|}{$\begin{array}{l}\text { Principle 1: The partnership schemes take into account the long-term viability of key stakeholders' } \\
\text { economic objectives }\end{array}$} \\
\hline Criteria & Indicators \\
\hline \multirow{3}{*}{$\begin{array}{l}\text { 1. The scheme maintains a commercial } \\
\text { focus of key stakeholders' interest, and/ } \\
\text { or the scheme is commercially viable for } \\
\text { key stakeholders }\end{array}$} & 1.a. Comparative advantages increase \\
\hline & $\begin{array}{l}\text { 1.b. Available markets for tree-grower partners' planted } \\
\text { timber }\end{array}$ \\
\hline & $\begin{array}{l}\text { 1.c. Income diversity options available to bridge the } \\
\text { waiting period between planting and timber } \\
\text { harvesting }\end{array}$ \\
\hline 2. Economic risks are anticipated & $\begin{array}{l}\text { 2.a. A certain proportion of revenues from the main } \\
\text { timber crops is reinvested to sustain the plantation } \\
\text { and partnership scheme (an effective reinvestment } \\
\text { mechanism does exist) }\end{array}$ \\
\hline \multicolumn{2}{|c|}{ Principle 2: The share of benefits is based on the proportional inputs by each stakeholder } \\
\hline Criteria & Indicators \\
\hline $\begin{array}{l}\text { 1. Mechanism for fair economic } \\
\text { relationship and economic power } \\
\text { sharing exists }\end{array}$ & 1.a. A fair benefit-sharing agreement exists \\
\hline \multirow[t]{2}{*}{ 2. A fair valuation of stakeholders' inputs } & 2.a. All economic inputs are well-recorded \\
\hline & $\begin{array}{l}\text { 2.b. Transparent information is available to all stakeholders } \\
\text { or information is circulated transparently }\end{array}$ \\
\hline
\end{tabular}

\section{Social-cultural aspects}

The first principle is mainly based on the underlying assumption that partnership schemes should meet not only the commercial objectives of the company partner, as highlighted by the economic principles, but also the socio-cultural objectives, which are mainly in the best 
interests of local tree-growers. In order to achieve these objectives, long-term rights (not necessarily tenure or land title; Race 1999) should be legally clarified prior to the contractual agreement. Acknowledging long-term, local tree-growers' land tenure and rights over lands included under the partnership schemes, means that their freedom to practice traditions related to the forest resources or land is acknowledged. Therefore, in assessing mutually beneficial partnerships under partnership schemes, the second principle measures the existence of a mechanism to promote a balance in the power of different stakeholders. In practical terms, this could be an effective role for a third party, such as the local government or an NGO, as the mediator in conflict resolution or in facilitating the initiation of partnerships schemes.

\begin{tabular}{|c|c|}
\hline \multicolumn{2}{|c|}{$\begin{array}{l}\text { Principle 1: The implementation of partnership schemes satisfies the social objectives of various key } \\
\text { stakeholders }\end{array}$} \\
\hline Criteria & Indicators \\
\hline \multirow{2}{*}{$\begin{array}{l}\text { 1. Various social objectives of key } \\
\text { stakeholders must be recognised in the } \\
\text { agreement and met in order to optimise } \\
\text { the adoption of partnership schemes }\end{array}$} & $\begin{array}{l}\text { 1.a. Long-term land status/rights have been transparently } \\
\text { settled prior to the establishment of the forest } \\
\text { plantation, and are respected by key stakeholders }\end{array}$ \\
\hline & $\begin{array}{l}\text { 1.b. Local socio-cultural needs of key stakeholders are } \\
\text { being considered and met whenever appropriate }\end{array}$ \\
\hline \multicolumn{2}{|c|}{ Principle 2: The partnership schemes balance the differences among key stakeholders } \\
\hline Criteria & Indicator \\
\hline \multirow{2}{*}{$\begin{array}{l}\text { 1.There is a mechanism to balance the } \\
\text { different powers of stakeholders }\end{array}$} & 1.a. Conflict resolution mechanism exists \\
\hline & 1.b. Possibility to renegotiate the agreements exists \\
\hline
\end{tabular}

\section{Ecological aspects (mostly determined by external conditions)}

The establishment of forestry plantations in tropical countries has been vehemently blamed as the main cause of the degradation of the environmental services of forests. Therefore, in assessing mutually beneficial partnerships for establishing forestry plantations, under the framework of SFPM it is necessary to address the maintenance of the ecological integrity, mainly to ensure the sustainability of essential environmental services. Analysing the ecological impacts of developing plantation forestry requires a detailed analysis, which is not possible in a short time frame.

\begin{tabular}{ll}
\hline Principle 1: Ecological integrity is maintained & \\
\hline Criteria & Indicators \\
\hline 1. Ecosystem function is maintained & $\begin{array}{l}\text { 1a.The adverse impacts of plantation management } \\
\text { practices are maintained within critical limits as defined } \\
\text { by regional conservation objectives }\end{array}$ \\
\hline 2.Ecological risks are minimised & $\begin{array}{l}\text { 2a.Species diversity is maintained at plot, landscape or } \\
\text { regional levels }\end{array}$ \\
\cline { 2 - 2 } \begin{tabular}{l} 
2b.Plans for fire prevention exist \\
\cline { 2 - 2 }
\end{tabular} & $\begin{array}{l}\text { 2c. Water quantity and quality are maintained } \\
\begin{array}{l}\text { 2d. The development of plantations is focussed on } \\
\text { degraded lands }\end{array}\end{array}$ \\
\hline
\end{tabular}




\section{Policy aspects (mostly determined by external conditions)}

Ensuring that the implementation of partnerships is mutually beneficial and based on agreements, respected by all key stakeholders, requires positive, government support (local and central) that is translated into conducive policy and institutional frameworks. Without these, it is rare that partnerships can be sustained in the long term. For plantation forestry crops, the growing period varies from five to eight years for Acacia mangium to 35 to 50 years for Tectona grandis (teak). Over such long periods, there are many potential sources of conflict that could place pressure on the partnership arrangement and agreement. Race (1999: 9) observed that, although a contractual arrangement may be agreed and signed with good intent and willingly by both parties for a mutually beneficial outcome, market conditions and/or the socio-political context can change dramatically over the growing period of timber crops.

Principle 1: Policy and institutional frameworks are conducive to partnership and agreement within the framework of sustainable forestry plantation management

\begin{tabular}{|c|c|}
\hline Criteria & Indicator \\
\hline \multirow[t]{3}{*}{$\begin{array}{l}\text { 1. Inter-sectoral polices are coherent with the policies } \\
\text { on forestry plantation development }\end{array}$} & $\begin{array}{l}\text { 1a. Policies for forestry plantation } \\
\text { development exist }\end{array}$ \\
\hline & $\begin{array}{l}\text { 1b. Other forestry policies are coherent } \\
\text { with policies on forestry plantation } \\
\text { development }\end{array}$ \\
\hline & $\begin{array}{l}\text { 1c. Effective instruments for inter-sectoral co- } \\
\text { ordination on land management, mainly } \\
\text { for plantation development }\end{array}$ \\
\hline \multirow[t]{2}{*}{ 2. Conducive policy on land tenure exists } & $\begin{array}{l}\text { 2a. Coherence inter-sectoral land tenure } \\
\text { policies at national and regional levels }\end{array}$ \\
\hline & $\begin{array}{l}\text { 2b. Coherence of rules on land tenure } \\
\text { between national and local communities }\end{array}$ \\
\hline 3. Precautionary policies exist & $\begin{array}{l}\text { 3a. Regional policies on landscape } \\
\text { management on fire mitigation }\end{array}$ \\
\hline
\end{tabular}

\section{Definitions of Principle, Criterion, Indicator, and Verifier}

The assessment guidelines use similar definitions of the set of principles and criteria based on the toolbox of Criteria and Indicators (C and I) for Sustainable Forest Management developed by the CIFOR Criteria and Indicator Team (1999). 


\section{DEFINITIONS}

Principle: A fundamental truth or law as the basis of reasoning or action. Principles in the context of sustainable forest management are seen as providing the primary framework for managing forests in a sustainable fashion. They provide the justification for criteria, indicators and verifiers. Consider that principles embody human wisdom. Wisdom ${ }^{1}$ is defined as a small increment in knowledge created by a person's (group's) deductive ability after attaining a sufficient level of understanding of a knowledge area.Wisdom therefore depends on knowledge.

Criterion: A principle or standard that a thing is judged by. A criterion can therefore be seen as a'second order' principle, one that adds meaning and operationality to a principle without itself being a direct measure of performance. Criteria are the intermediate points to which the information provided by indicators can be integrated and where an interpretable assessment crystallizes. Principles form the final point of integration. In addition to considering criteria to be second-order principles, treat them also as reflections of knowledge. Knowledge $a$ is the accumulation of related information over a long period of time. It can be viewed as a large-scale selective combination or union of related pieces of information.

Indicator: An indicator is any variable or component of the forest ecosystem or management system used to infer the status of a particular criterion. Indicators should convey a 'single meaningful message'. This 'single message' is termed information'. It represents an aggregate of one or more data elements with certain established relationships. It is important to understand that indicators, in the sense they used here, are not to be mistaken as conditions for fulfilment of a criterion, nor are they to be understood as a mandatory set of rules, guidelines of prescriptions. Rather, they are a series of messages that require interpretation and cross evaluation before they can satisfactorily inform an assessment of forest management, social or forest condition.

Verifier: Data or information that enhances the specificity or the ease of assessment of an indicator. The fourth level of specificity, verifiers provide specific details that would indicate or reflect a desired condition of an indicator. They add meaning, precision and usually also site-specificity to an indicator. They may define the limits of a hypothetical zone from which recovery can still safely take place (performance threshold/target). On the other hand, they may also be defined as procedures needed to determine satisfaction of the conditions postulated in the indicator concerned (means of verification). In the Tropenbos ${ }^{2}$ terminology these might be classified as sub-indicators.

Notes:

1. Definition based on the four basic entities in Information Theory (Liang 1994)

2. Lammerts van Bueren, E.M and Bloom, E.M 1997. Hierarchical Framework for the Formulation of Sustainable Forest Management Standards

Source:The CIFOR Criteria and Indicators Toolbox Series No. 2 


\section{Annex 2. Bases and assumptions of the financial analysis}

\section{Community-Based Forest Management Program}

\section{a. Don Mariano Perez Farmers Multipurpose Cooperative, Inc.}

1. The cost of community organising of $\mathrm{PhP} 1,500,000$ was distributed over three years as follows:

\begin{tabular}{lccc}
\hline Year & $\begin{array}{c}\text { \% of Funds } \\
\text { Released* }\end{array}$ & $\begin{array}{c}\text { Post } \\
\text { PhP }\end{array}$ & $\begin{array}{c}\text { PhP } \\
\mathbf{( 2 0 0 0 )}\end{array}$ \\
\hline 1 & 50 & 750,000 & $1,059,300$ \\
\hline 2 & 35 & 525,000 & 741,510 \\
\hline 3 & 15 & 225,000 & 317,790 \\
\hline
\end{tabular}

*assumed for the purpose of the financial analysis

The 1995 values were adjusted to their 2000 values using the average inflation rate (1995 to 2000) of $7.15 \%$.

2. Activities for plantation development, assisted natural regeneration and timber harvesting were based on the Community Resource Management Framework that was prepared in the year 2000. The costs are as follows:

a. Plantation Development Targets and Cost

\begin{tabular}{lcc}
\hline Year & $\begin{array}{c}\text { Area } \\
\text { (ha/year) }\end{array}$ & $\begin{array}{c}\text { Cost } \\
\text { (PhP/year) }\end{array}$ \\
\hline $4-18$ & 20.0 & 362,880 \\
\hline $19-35$ & 16.4 & 297,562 \\
\hline
\end{tabular}

b. Assisted natural regeneration development target and cost

\begin{tabular}{lcc}
\hline Year & $\begin{array}{c}\text { Area } \\
\text { (ha/year) }\end{array}$ & $\begin{array}{c}\text { Cost } \\
\text { (PhP/year) }\end{array}$ \\
\hline 1 & 23.75 & 134,036 \\
\hline 2 & 23.74 & 194,336 \\
\hline $3-25$ & 23.74 & 254,635 \\
\hline
\end{tabular}

3. The cost of timber harvesting was based on the projected harvest from the annual cutting area (ACA) as provided in the Community Resource Management Framework, i.e.

Cost of timber harvesting $=$ yield/ha $x A C A x$ cost of production 
4. The projected revenues were based on the Annual Work Plan as follows:

\begin{tabular}{|c|c|c|c|c|}
\hline Source & Year & Area & AAC $\left(\mathrm{m}^{3} /\right.$ year $)$ & $\begin{array}{c}\text { Gross Revenue } \\
\text { (PhP) }\end{array}$ \\
\hline \multicolumn{5}{|c|}{ Forest Development } \\
\hline & 1 & 23.74 & 345.11 & $1,949,093$ \\
\hline & $2-35$ & 23.74 & 379.25 & $2,141,863$ \\
\hline \multicolumn{5}{|c|}{ Timber Stand Improvement } \\
\hline - Sawlog & 8 & & & 543,837 \\
\hline - Fuelwood & 8 & & & 1,950 \\
\hline
\end{tabular}

5. A 25-year discounting period was used.

\section{b. ANAK-Jamindan}

1. The cost and revenue items were based on the Community Resource Management Framework prepared by the people's organisation in 1999. The costs of community organising and comprehensive site development were adjusted to 2000 values using the average inflation rate of $6.475 \%$ (1997 to July 2000).

2. The costs of community organising and comprehensive site development of $\mathrm{PhP} 3,858,701$ and $\mathrm{PhP} 2,892,376$, respectively, were based on the budget allocated by the Department of Environment and Natural Resources. These were distributed as follows:

\begin{tabular}{lccccc}
\hline \multirow{2}{*}{ Year } & $\begin{array}{c}\text { \% of Funds } \\
\text { Released* }\end{array}$ & \multicolumn{2}{c}{ Community organising } & \multicolumn{2}{c}{ Comprehensive site development } \\
\cline { 2 - 6 } & $\mathbf{1 9 9 7}$ & $\mathbf{2 0 0 0}$ & 1997 & 2000 \\
$\mathrm{PhP}$ & $\mathrm{PhP}$ & $\mathrm{PhP}$ & $\mathrm{PhP}$ \\
\hline 1 & 50 & $1,929,350$ & $2,328,919$ & $1,446,188$ & $1,745,694$ \\
\hline 2 & 35 & $1,350,545$ & $1,630,243$ & $1,012,332$ & $1,221,985$ \\
\hline 3 & 15 & 578,805 & 698,676 & 433,856 & 523,708 \\
\hline
\end{tabular}

*assumed for the purpose of the financial analysis

Comprehensive site development includes nursery operations, plantation establishment and maintenance, infrastructure and forest protection. As such, no forest protection costs were indicated from Years $1-3$. The forest protection cost from Year 4 to Year 25 was based on Department of Environment and Natural Resources' cost standard of PhP 226.10/ha, and covers an area of 126.95 ha.

The cost of comprehensive site development beginning Year 8 until Year 25 covers the cost of replanting, assumed to be $\mathrm{PhP}$ 50,000/year.

3. The harvest schedule for the different years was based on the physical development activities and targets indicated in the Annual Work Plan. In the absence of price estimates in the plan, the costs and revenues were projected using the following assumptions: 
a. Prices:

\begin{tabular}{lcc}
\hline Species & Rotation & $\begin{array}{c}\text { Price } \\
\left(\mathbf{P h P} / \mathbf{m}^{\mathbf{3}} \mathbf{)}\right.\end{array}$ \\
\hline Gmelina arborea & 8 & 2,000 \\
\hline Acacia mangium & 8 & 2,000 \\
\hline Swietenia macrophylla & $16-25$ & 4,000 \\
\hline
\end{tabular}

b. The harvesting costs were based on ERDB's 1998 estimate of PhP 44,542/ha, adjusted to its 2000 value of $\mathrm{PhP} 47,753 / \mathrm{ha}$.

c. Projected harvesting cost and revenue

\begin{tabular}{llcccc}
\hline Year & Species & $\begin{array}{c}\text { Area } \\
\text { (ha/year) }\end{array}$ & $\begin{array}{c}\text { Yield } \\
\left(\mathbf{m}^{\mathbf{3}} / \mathbf{h a}\right)\end{array}$ & $\begin{array}{c}\text { Total revenues } \\
\text { (PhP/year) }\end{array}$ & $\begin{array}{c}\text { Harvesting cost } \\
\text { (PhP/year) }\end{array}$ \\
\hline 8-15 & Gmelina arborea & 5 & 60 & 600,000 & 238,768 \\
\hline & Acacia mangium & 5 & 60 & 600,000 & 238,768 \\
\hline $16-25$ & Swietenia macrophylla & 6 & 160 & $3,840,000$ & 286,518 \\
\hline
\end{tabular}

3. The discounting period used is 25 years, corresponding to the duration of the agreement.

\section{c. Sta. Maria-Magkalape Tree Planters Association}

1. The Annual Work Plan was prepared in 2000; thus, the revenues and costs other than those for community organising and comprehensive site development were no longer compounded. The community organising and comprehensive site development components had to be adjusted because these were allocated in 1995. The average inflation rate from $1995-2000$ is $7.15 \%$.

2. The cost of community organising ( $\mathrm{PhP} 1,588,125)$ was distributed over three years as follows:

\begin{tabular}{lccc}
\hline & & \multicolumn{2}{c}{ Cost } \\
\cline { 3 - 4 } Year & \% of funds released* & $\begin{array}{c}\mathbf{1 9 9 5} \\
\mathbf{( P h P )}\end{array}$ & $\begin{array}{c}\mathbf{2 0 0 0} \\
\text { (PhP) }\end{array}$ \\
\hline$Y_{1}(1995)$ & $50 \%$ & 794,062 & $1,121,544$ \\
\hline$Y_{2}(1996)$ & $35 \%$ & 555,844 & 785,074 \\
\hline$Y_{3}(1997)$ & $15 \%$ & 238,219 & 336,460 \\
\hline
\end{tabular}

* assumed for the purpose of the financial analysis

3. The cost of the 309- ha plantation developed by the Association under Loan 2 was computed as follows: 


\begin{tabular}{lccrcc}
\hline $\begin{array}{l}\text { Area developed } \\
\mathbf{x} \text { cost }\end{array}$ & $\mathbf{Y}_{\mathbf{2}}$ & $\mathbf{Y}_{\mathbf{3}}$ & $\mathbf{Y}_{\mathbf{4}}$ & $\mathbf{Y}_{\mathbf{5}}$ & $\mathbf{Y}_{\mathbf{6}}$ \\
\cline { 2 - 6 } & $\mathbf{P h P}$ & $\mathbf{P h P}$ & $\mathbf{P h P}$ & $\mathbf{P h P}$ & $\mathbf{P h P}$ \\
\hline 103 ha x PhP 16,438/ha & $1,693,114$ & $1,693,114$ & $1,693,114$ \\
\hline 103 ha x PhP 1,986/ha & & 204,558 & 204,558 & 204,558 \\
\hline 103 ha x PhP 1,986/ha & & 204,558 & 204,558 & 204,558 \\
\hline TOTAL (1995) & $1,693,114$ & $1,897,672$ & $2,102,230$ & 409,116 & 204,558 \\
\hline (2000) & $2,391,354$ & $2,680,272$ & $2,969,190$ & 577,835 & 288,918 \\
\hline
\end{tabular}

4. Forest protection was included in the comprehensive site development from Years 2 to 4. Beginning Year 5 until Year 25, this was computed using the Department of Environment and Natural Resources estimate as follows:

PhP 226.10/ha $x 509$ ha (loans 1 and 2 area) $=\operatorname{PhP} 115,085(1995)$

PhP $162,546(2000)$

5. The comprehensive site development costs indicated beginning Year 7 are based on the cost of replanting the harvested areas, assured to be $\mathrm{PhP} 16,436 / \mathrm{h}$. The areas to be replanted are 25 ha/year from Year 5 to Year 12, and 70.44 ha/year from Year 13 to Year 25.

6. The projected revenues were based on the Resource Use Permit. The average yield is 32 $\mathrm{m}^{3}$

7. The harvesting costs were based on the estimates in the Resource Use Permit. The harvesting cost was adjusted in Year 13 due to the bigger area to be harvested.

8. The discounting period used is 25 years.

\section{Integrated Forest Management Program}

\section{a. Woodland Wood Products, Inc.}

1. WWPI had a feasibility study in its Comprehensive Development and Management Plan (CDMP), and the information provided was used. However, some adjustments were made, particularly for the harvesting costs for years 12, 14, and 25. It appears that these were erroneous entries (typographical or otherwise) and affected the indicators. Since the CDMP was prepared in 1995, the values were adjusted to their Year 2000 values using an average inflation rate from 1995 to 2000 of $7.15 \%$.

2. The discounting period used is 25 years, corresponding to the duration of the agreement.

\section{b. Iloilo Washington Commercial}

1. The cost and revenue estimates were based on the company's activities in its Indicative Development Plan. Since no cost and yield estimates were provided, the projections were based on the areas allocated to different tree species and the cost and revenue estimates provided by the Ecosystems Research and Development Bureau's "Development and Management of Forest Plantations" Guidebook, 1998. The estimates were adjusted to 
their 2000 values using an average inflation rate from 1998 to 2000 of $3.54 \%$.

2. The discounting period used is 25 years, corresponding to the duration of the agreement.

\section{c. Casilayan Softwood Development Corp.}

1. The development expenses were taken from the company's Comprehensive Development and Management Plan. Since this was prepared in 1983, the expenses were adjusted to their 2000 values using an average inflation rate from 1983 to 2000 of $13.6 \%$.

2. The projected harvestable volumes were based on the assumption that the plantations would be clear-cut with a yield of $136.92 \mathrm{~m}^{3} /$ ha. However, the company has not practiced clear-cutting. Thus, this study used a more conservative yield of $100 \mathrm{~m}^{3} / \mathrm{ha}$, and a price of $\mathrm{PhP} 2,300 / \mathrm{m}^{3}$ (delivered), the price at which the company sells Endospermum peltatum logs to its sister company.

3. Assuming a conservative mean annual increment of $10 \mathrm{~m}^{3} / \mathrm{ha}$, the thinning in Year 4 was based on the assumption that $25 \%$ of the volume would be thinned, and the wood would be sold for PhP $1,000 / \mathrm{m}^{3}$. Thinning will be conducted from Year 4 to Year 10 only.

4. The discounting period used is 25 years, corresponding to the duration of the agreement. 


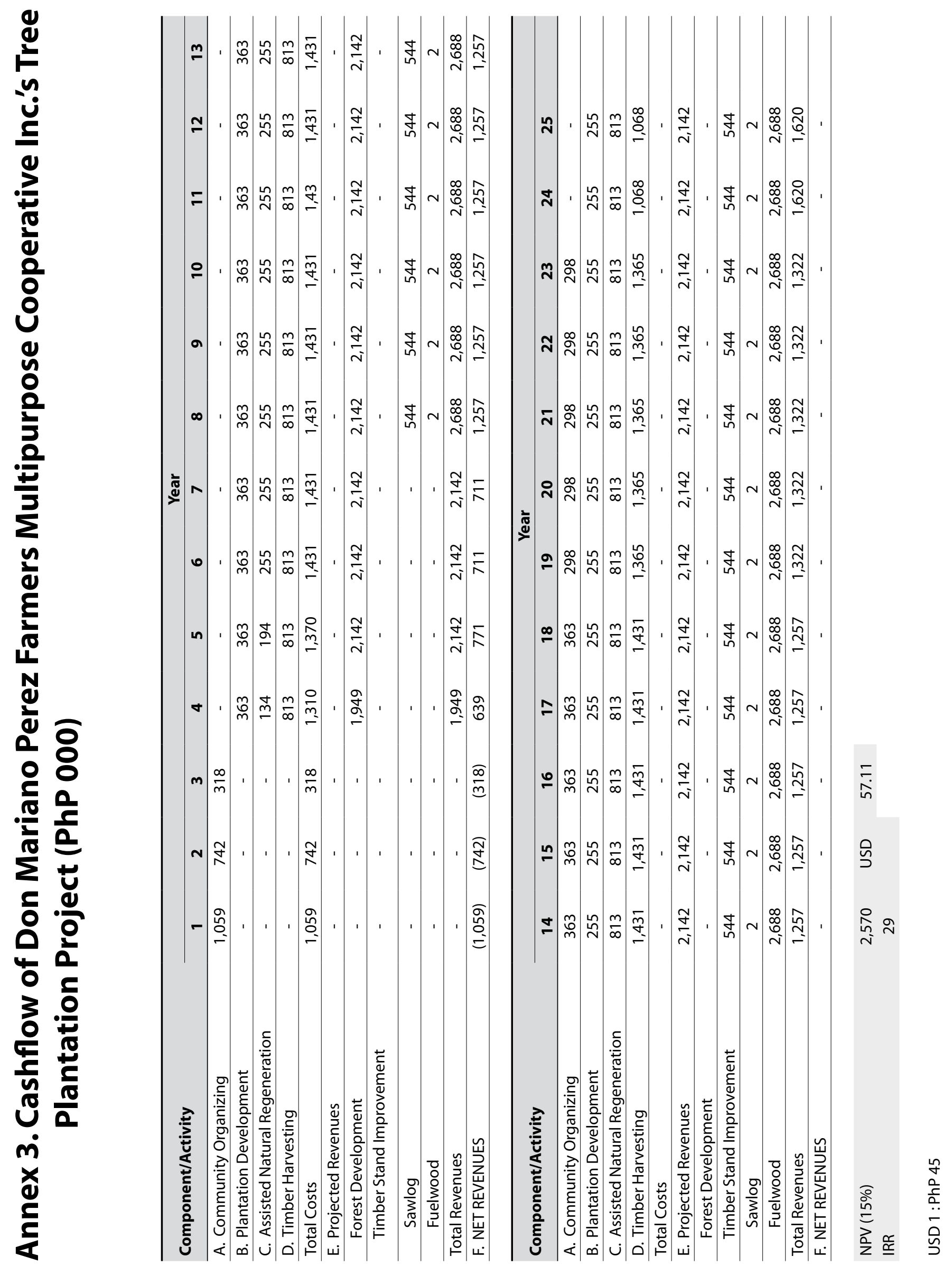




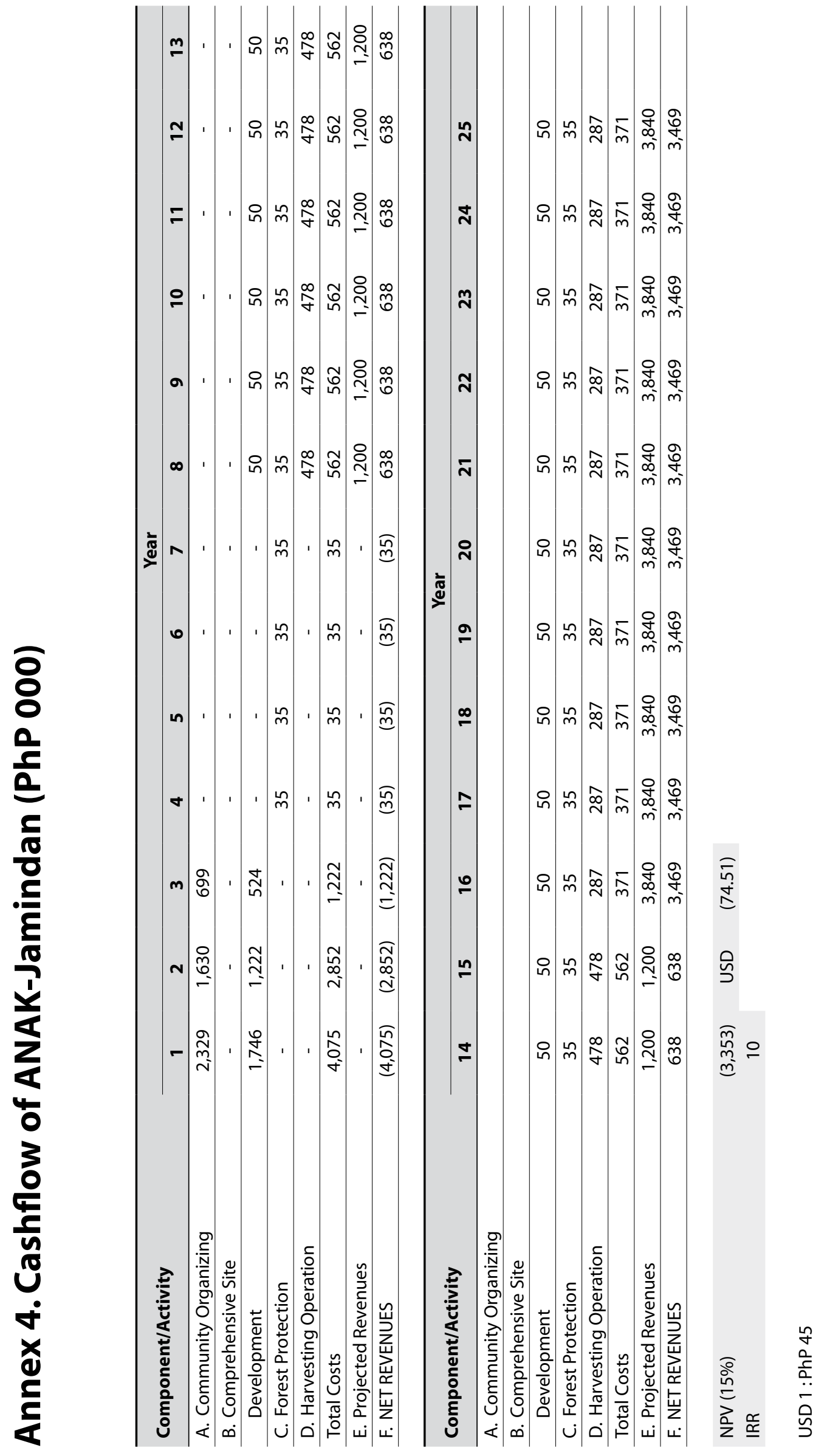




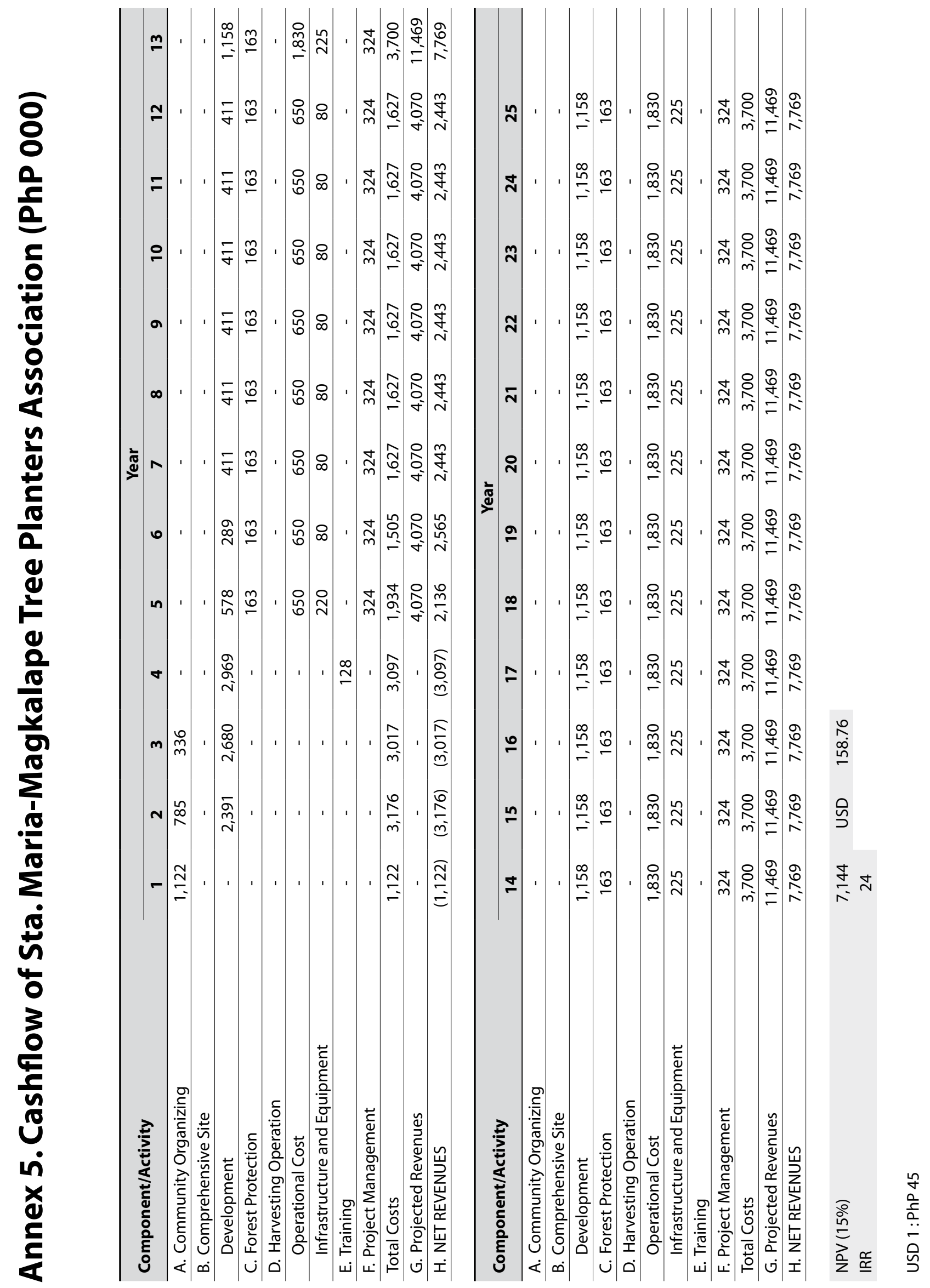




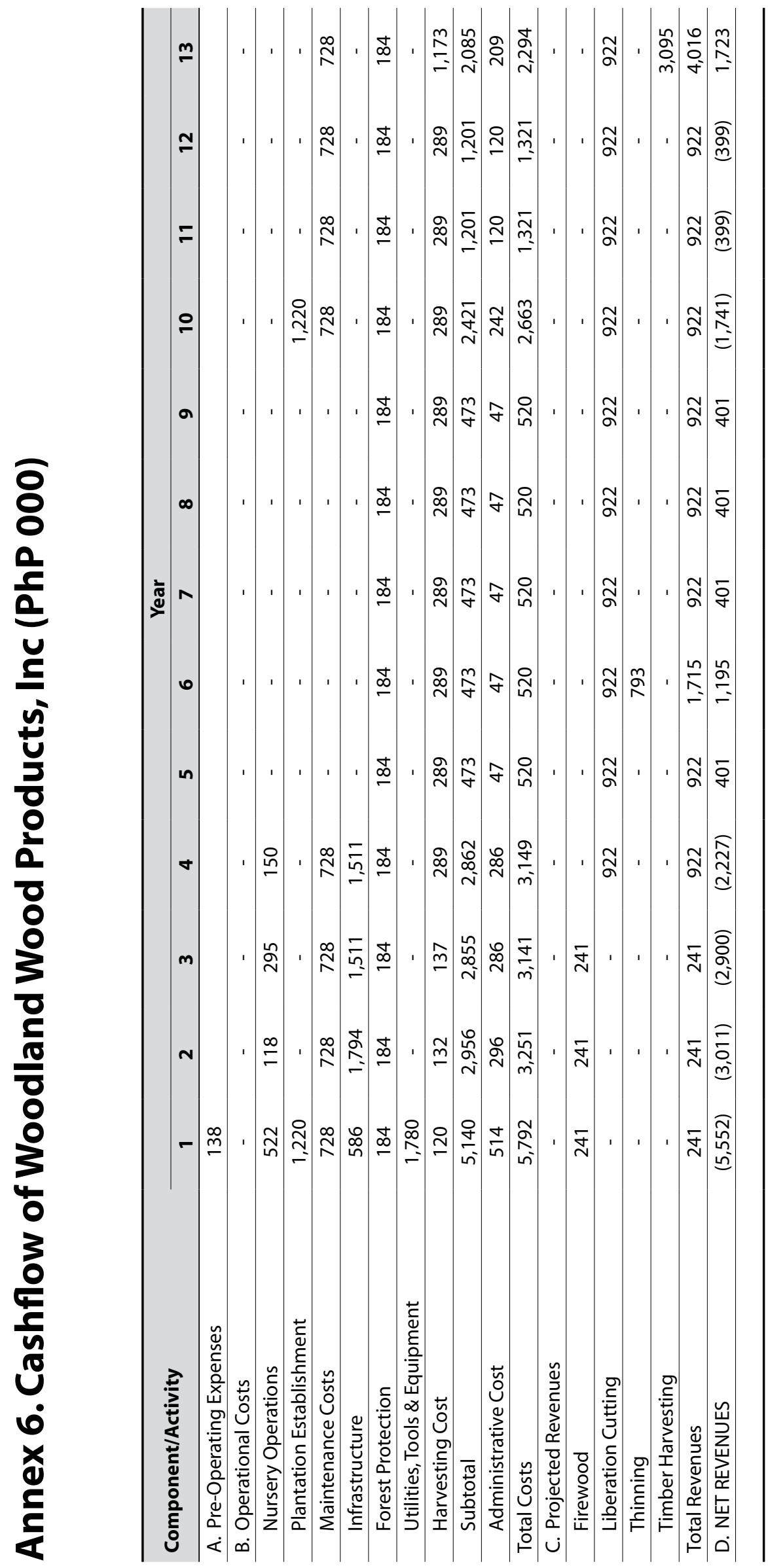




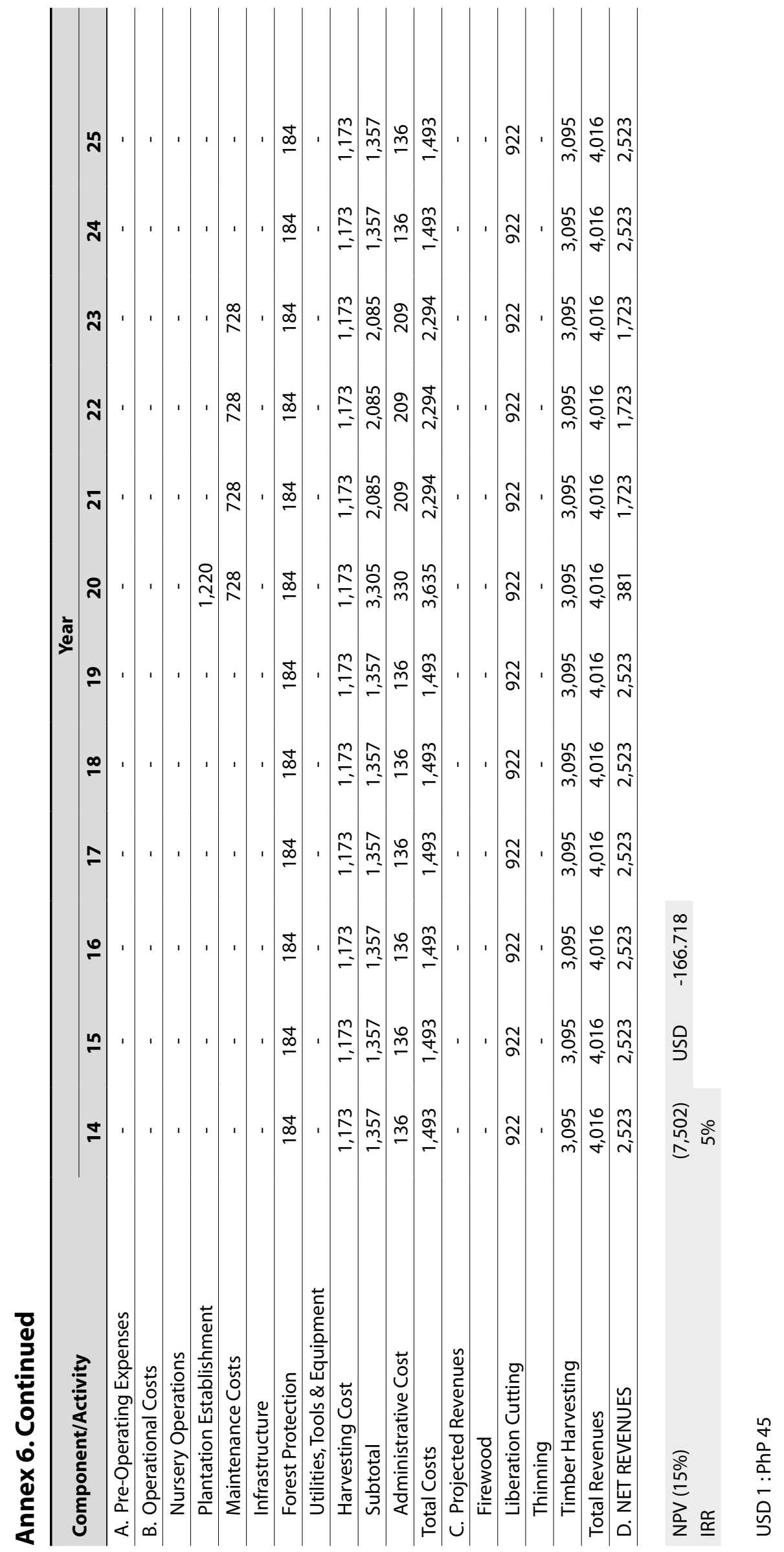




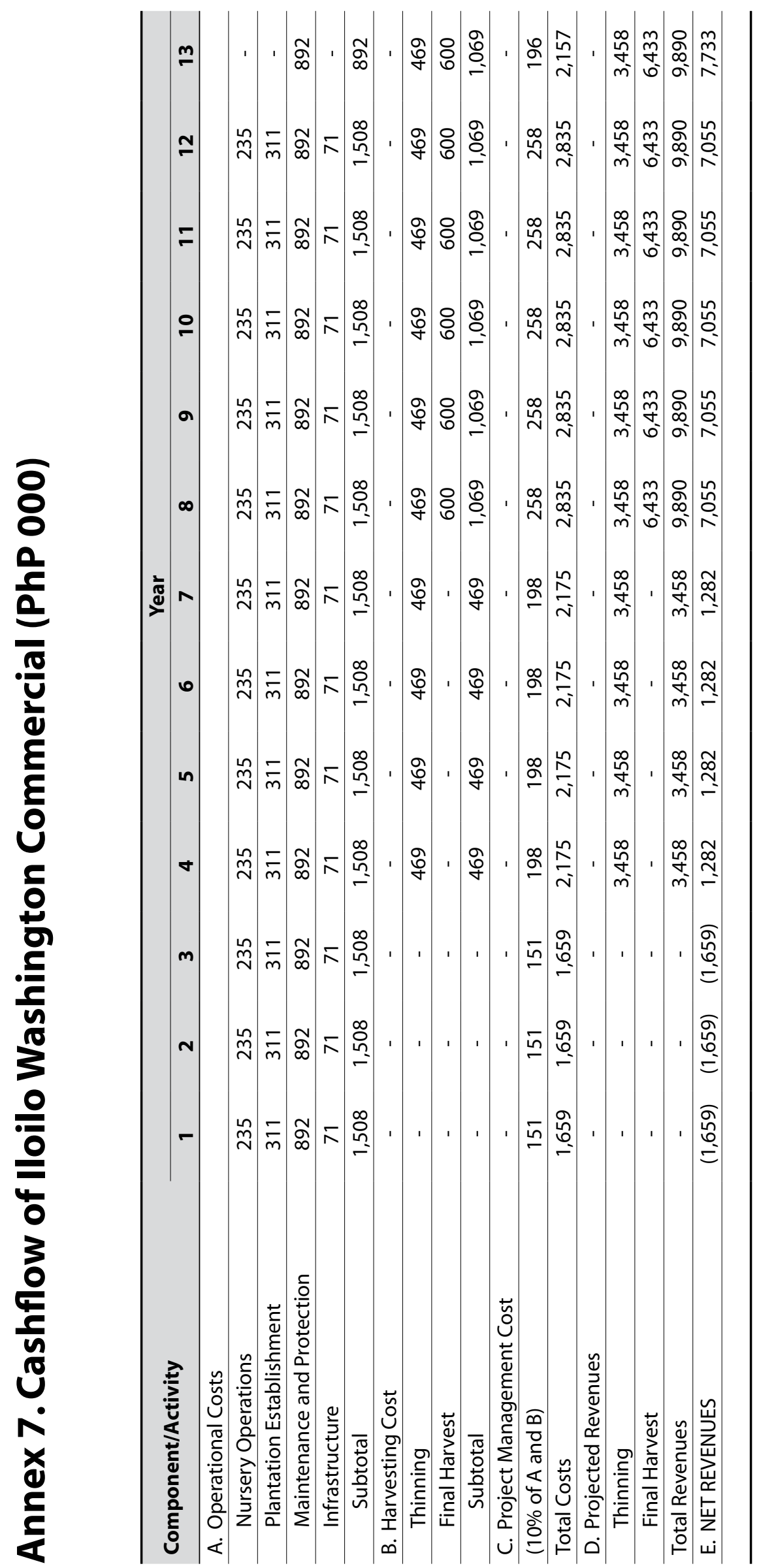




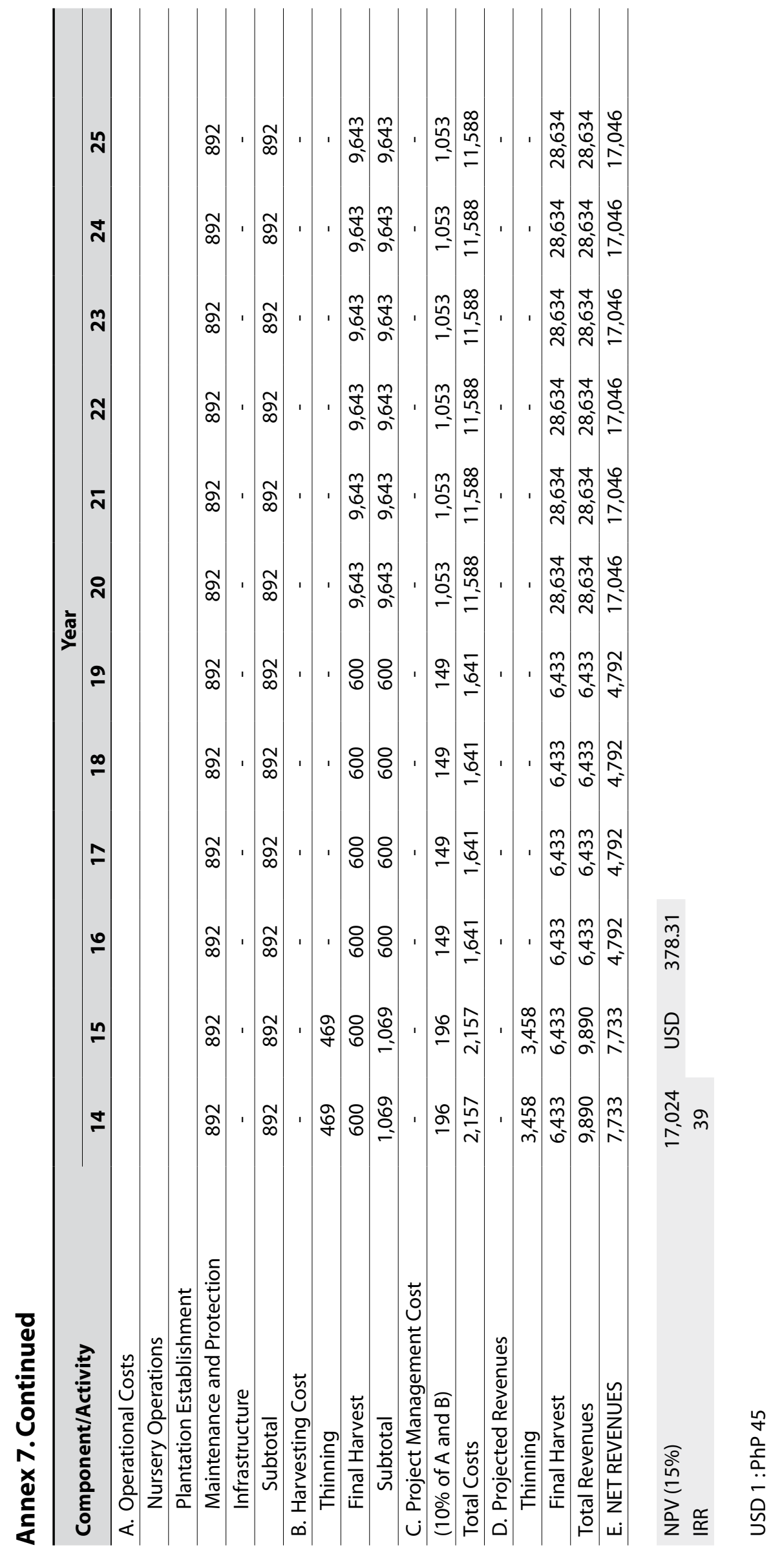




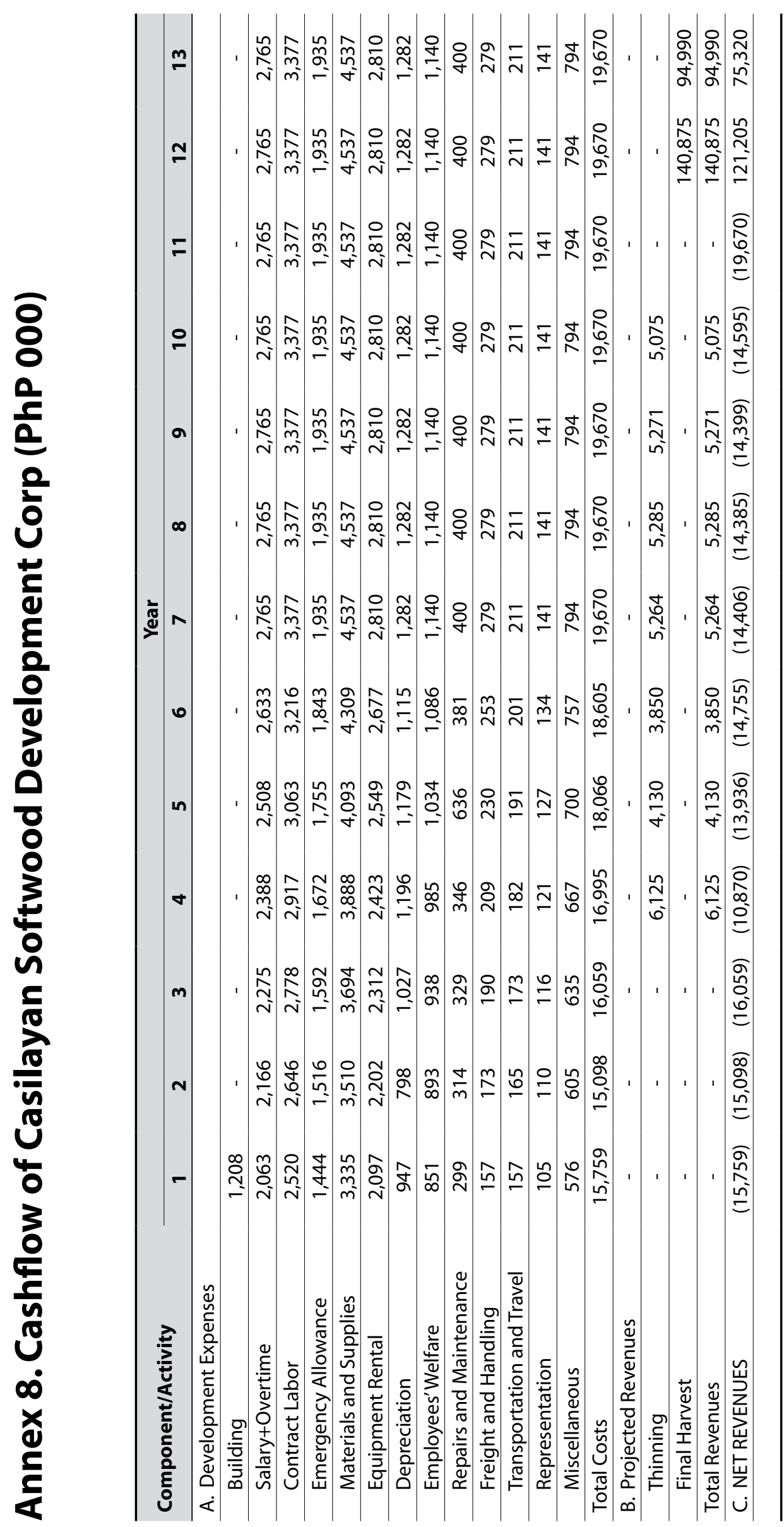




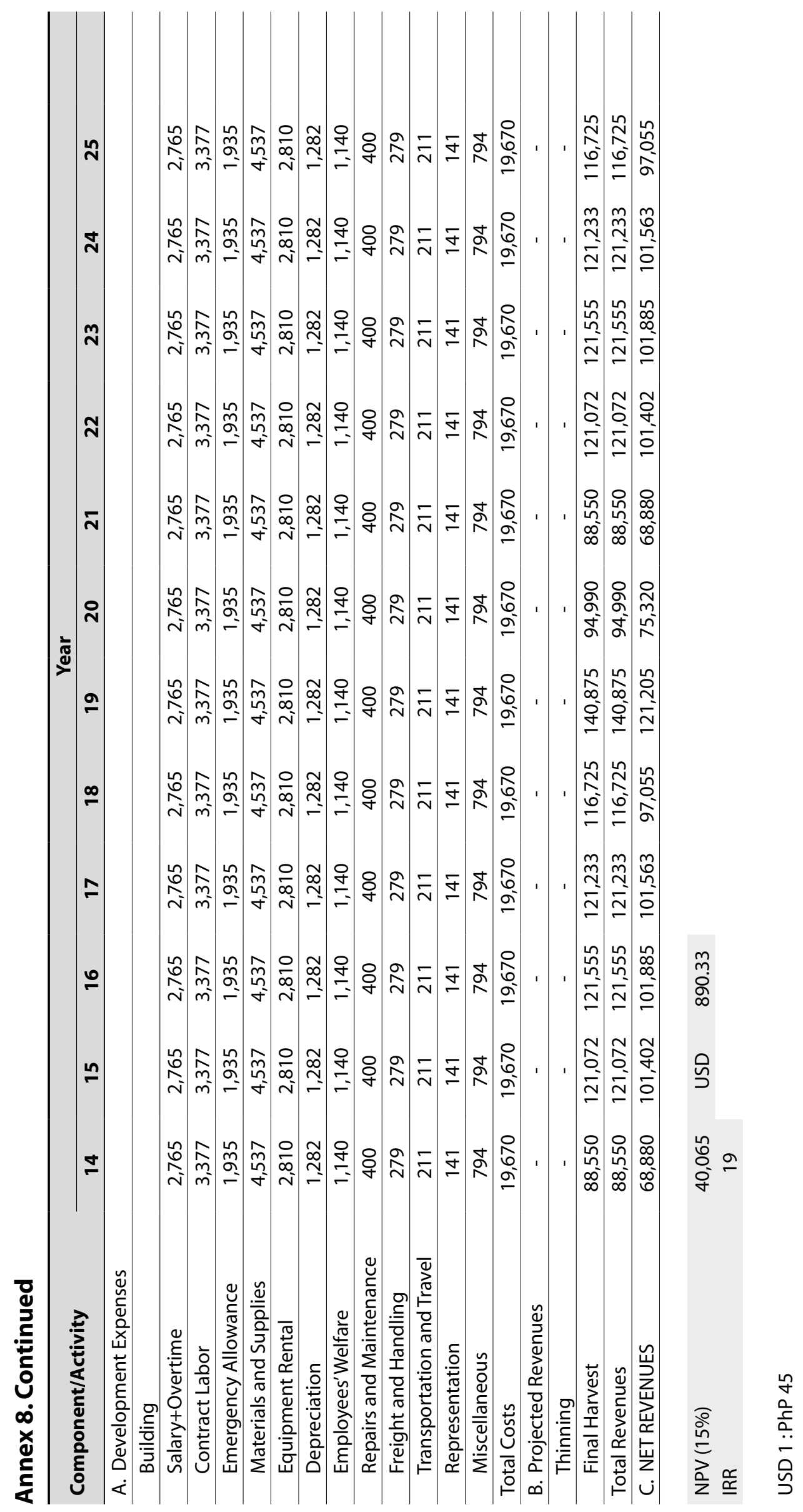




\section{Endnotes}

${ }^{1}$ A people's organization can be an association, cooperative, federation or other legal entity established by the community to undertake collective action to address community concerns and needs and mutually share the benefits from the endeavor (DENR Administrative Order 96-29).

${ }^{2}$ A barangay is the smallest local government unit in the Philippines

${ }^{3}$ The Community Resource Management Framework defines the terms and procedures for access, use and protection of natural resources within the area. It should be consistent with the overall management strategy of the watershed to which the area belongs, and should be prepared by the community.

${ }^{4}$ The Resource Use Plan should be prepared for each resource to be managed and utilized, and is not limited to only timber but may also include rattan, resins, and other forest products. It should be based on the results of the resource inventory to be undertaken by the Department of Environment and Natural Resources. Once accepted, it serves as the people's organization's permit to utilize the resource.

5 The Annual Work Plan embodies the operationalisation of the Community Resource Management Framework and the Resource Use Plan. It indicates the specific utilization targets for the year, resource development and protection, organizational strengthening, and enterprise development.

${ }^{6} 1 \mathrm{~m}^{3}=424$ board feet $(\mathrm{bd} \mathrm{ft})$

${ }^{7}$ Removal of competing vegetation or weeds in a strip

${ }^{8}$ Removal of competing vegetation or weeds in a ring around the seedling 


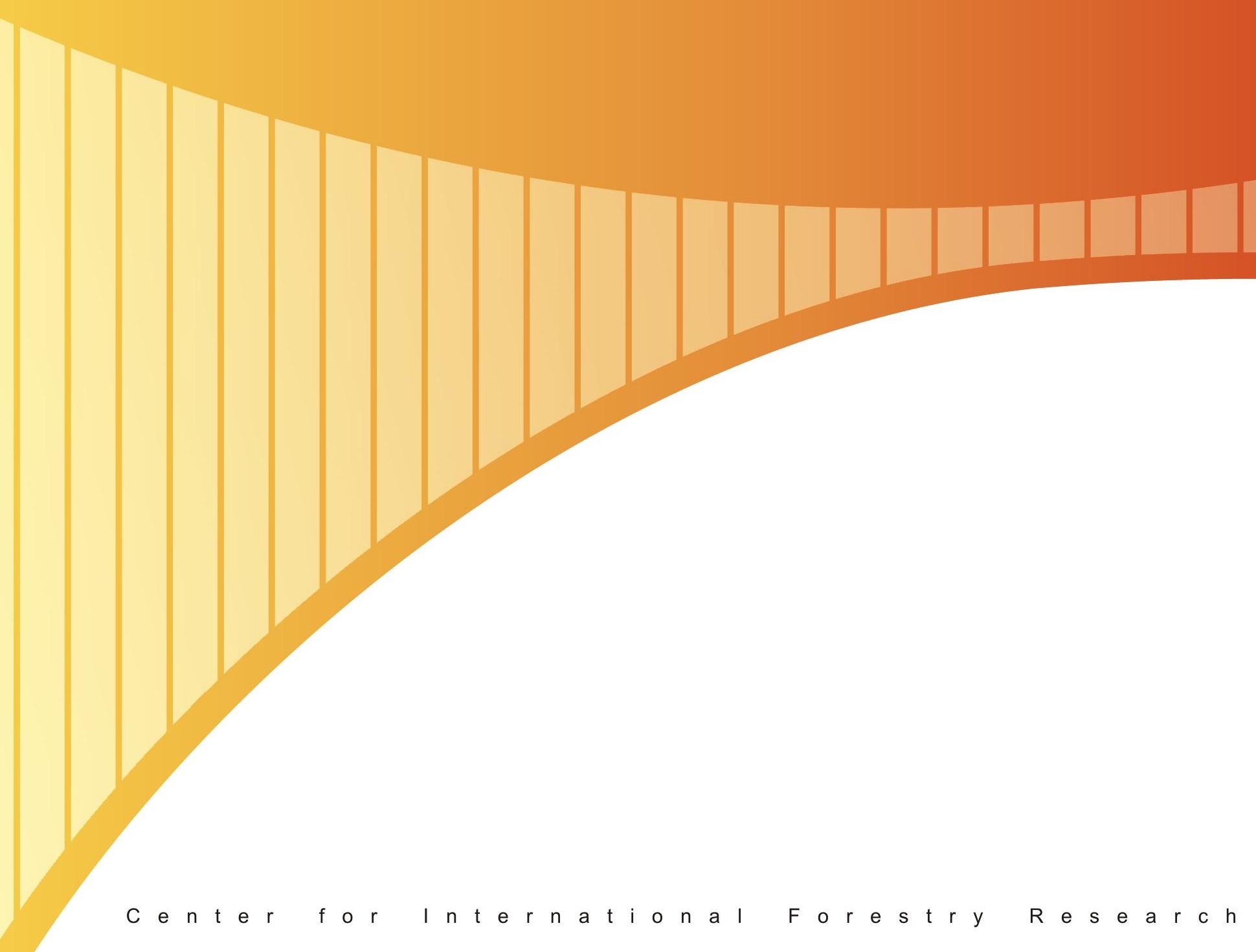

